University of Louisville

ThinkIR: The University of Louisville's Institutional Repository

Electronic Theses and Dissertations

1941

\title{
Lay participation in the Private Family Agency, Louisville, Kentucky.
}

Mildred E. Bateman

University of Louisville

Follow this and additional works at: https://ir.library.louisville.edu/etd

Part of the Social Work Commons

\section{Recommended Citation}

Bateman, Mildred E., "Lay participation in the Private Family Agency, Louisville, Kentucky." (1941). Electronic Theses and Dissertations. Paper 1668.

https://doi.org/10.18297/etd/1668

This Master's Thesis is brought to you for free and open access by ThinkIR: The University of Louisville's Institutional Repository. It has been accepted for inclusion in Electronic Theses and Dissertations by an authorized administrator of ThinkIR: The University of Louisville's Institutional Repository. This title appears here courtesy of the author, who has retained all other copyrights. For more information, please contact thinkir@louisville.edu. 
UNIVERSITY OF LOUISVILLE

LAY PARTICIPATION IN THE PRIVATE FAMILY AGENCY

LOUISVILLE, KENTUCKY

\author{
A Dissertation \\ Submitted to the Faculty \\ Of the Graduate School of the University of Louisville \\ In Partial Fulfillment of the \\ Requi rements for the Degree \\ of \\ Master of Science in Social Administration \\ Division of Social Administration \\ by
}

Mildred E. Bateman

1941 
NAIAE OF STUDENT: Mildred E. Bateman

TITLE OF THESIS: Lay Participation in the Private

Family Agency, Louis ville, Kentucky

APPROVED BY READING COMMITTEE COMPOSED OF THE

FOLLOWING MEMBERS :

NAME OF DIRECTOR:

DATE: May 31, 1941 


\section{AN ACKNOWLEDGNENT}

For assistance with this thesis, the writer is indebted to many individuals. The writer wishes especially to acknowledge her gratitude to Dr. Margaret K. Strong for her lind assistance, encouragement and personal guidance; to Miss Esther Taylor for her suggestions and her kindness in placing agency material at the writer's disposal; to Miss Sarah Benedict for her encouragement and assistance; and to other nembers of the Family Service Organization staff for their helpfulness. 
LAY PARTICIPATION IN THE PRIVATE FAMILY AGENCY

LOUIS VILLE, KENTUCKY 
TABIE OF CONTENTS

PAGE

INTRODUCT ION

I THE CHARITY ORGANIZATION MOVEMENT

II THE CHARITY ORGANIZATION SOCIETY OF LOUISVILLE 1883-1907 20

A. ORGANIZATION AND STRUCTURE 20

Objects and Principles 21

Membership 22

Constitution 23

B. FINANCE 32

C. PROGRAM AND POLICIES 33

Relations with other Agencies and Institutions 34

District Conferences and Friendly Visitors 38

Care of Unemployed and Homeless 44

Annual Meotings $\quad 49$

D. SOCIAI PLANNING 50

Development of Community Resources 50

Legislation $\quad 52$

Local and National Participation 53

$\begin{array}{ll}\text { SUMMIARY } & 57\end{array}$

III THE ASSOCIATED CIIARITIES OF LOUISVILLE 1907-1922

A. ORGANIZATION AND STRUCTURE 64

Constitutional Revisions $\quad 64$

The Board and Policy Making $\quad 67$

B. FUNCT IONING COMMITTEES

Case Cormitte日 $\quad 72$

House Committe日 $\quad 76$

Housing Committeo $\quad 76$

Legal Aid Comitteo $\quad 76$

Wayfarers' Lodge Committeo $\quad 78$ 
Fimployment Comittee 79

Advisory Committee $\quad 79$

Special Committees $\quad 82$

Annual Meetings 83

C. RELATION WITH THE WELFARE LEAGUE AND OTHER AGENCIES 84

D. BUSINESS MANAGENENT AND FINANCE 88

E. SOCIAL PLANNING $\quad 89$

F. CHANGE OF NAME 96

$\begin{array}{lr}\text { SUMMARY } & 97\end{array}$

IV THE FAMILY SERVICE ORGANIZATION OF LOUISVILLE 1922-1929 100

$\begin{array}{ll}\text { A. ORGANIZATION AND STRUCTURE } & 106\end{array}$

The Board and the Executive Conmittee 109

B. RELATIONS WITH THE COMMUNITY CHEST AND OTHER AGENCIES 115

C. PLANNING FOR PUBLIC WELFARE 126

Legislation 132

Employment Services $\quad 135$

$\begin{array}{ll}\text { D. OTHER CORMITTEES } & 138\end{array}$

Home Economics 138

Building Committee 139

Volunteers $\quad 140$

Annual Meetings 143

$\begin{array}{ll}\text { SURAARY } & 144\end{array}$

V THE FAMILY SERVICE ORGANIZATION 1929-1938

A. ORGANIZATION AND STRUCTURE 152

The Board 152

Annual Meetings 158

B. FINANCE AND BUSINESS MANAGEUENT T 159 
PAGE

C. THE FAMILY SERVICE ORGANIZATION AND THE COMMUNITY CHEST

162

D. THE FAMILY SERVICE ORGAUIZATION AND THE CITY DEPARTMENT OF WELFARE

176

E. VOLUNTEERS

186

Stenographic Service

Notor Service

Case Work Service

Other Churoh Groups

Special Projects

186

186

187

188

189

F. PROFESSIONAL EDUCATION

190

SUMMARY

191

VI THE FAMILY SERVICE ORGANIZATION 1938-1941

193

A. THE COMUNITY CHEST SURVEY

195

B. CURREIT ORGANIZATION AND ACT IVITY

197

Constitutional Revisions

The Board

Standing and special Committees

Volunteors

Annual Mertings

197

199

204

207

207

SUMMARY

208

VII DISTRICT CONFERENCES OF THE FAMILY SERVICE ORGAIIZATION 1922-1941

209

A. MEMBERSHIP 211

B. FUNCTION 213

C. SCOPE OF SERVICE 216

$\begin{array}{ll}\text { SUMMARY } & 219\end{array}$

$\begin{array}{ll}\text { CONCLUSION } & 223\end{array}$

BIBLIOGRAPHY $\quad 232$ 
INTRODUCTION 


\section{INT RODUCT ION}

This study is being undertaken in an effort to clarify the position of the Family Service Organization in the community to which it belongs. In the present setting where so much of the agenoy's work is carried on by the professional staff, it seems necessary to remind ourselves that the private agency exists and operates in the community only because of the participation and support of a group of interested citizens. The part which these citizens have played and are playing in the agency's program presents an area of investigation. The present study aims to answer certain questions regarding the philosophy and social planning in the past fifty-eight years of a group of citizens that have proved themselves more then usually interested in and conversant with community problems.

The agency itself possesses a wealth of material to supply necessary information. Early records, except for the annual reports, are not available, but the detailed reporting of the agency's activities in the press seems to present an adequate picture of the program of that period. There are minutes of meetings of the Board of Directors from 1912 to the present, of the Executive Committee from 1917 to 1931, and the periodic minutes, reports and membership lists of other standing and special committees. Correspondence, reports of the Welfare League and Community Chest, of the Department of Welfare of the City of Louisville and of the Family Welfare Association of America provide information as do the Constitution and By-Laws and their revisions. Certain 
staff records--reports of the General Secretary and the District Supervisors, supervisors' discussions, and research studies supply facts rogarding lay participation. While all of these sources will be covered in detail, it seems wise because of the volume of material, to samplo approximately one-fourth of the minutes of District Conference meotings. There are gaps in the material and the adequacy of recording may at points be questioned, although the recording by citizens of what seoms important to them of their activities is significant. It is possible to supply some of the missing material through interviews with Mrs. R. P. Halleck, a member of the Board of Directors since 1909, Miss Esther Taylor, general secretary, and Miss Sarah Benedict, case supervisor. The work of Mrs. Bernice Ellis in compiling the history of the agency has provided a background for undertaking this study.

The approach is from the historical point of view. The development of the society seems to fall into various natural divisions. The agency operated as the Charity Organization society from 1884 to 1907 and as the Associated Charitios from 1907 to 1922. Since 1922, operation has been continuous under the name of the Family Service Organization. Within this last period of nineteen years there are again certain divisions resulting from developments in the community that affected the function of the agency. The program was drastically affected in 1929 by the burden of unemployment and it was necessary for the society to function as the major relief giving agency in the city. The cessation of public subsidy in 1938 which ereed the ageney again to derelop a service program brought about a clarification of the division of responsi- 
bility between the private agency and governmental services.

Certain questions seem pertinent as a guide to this study. What is the Family Service Organization? How has it evolved in respect to both structure and function since its initial organization? What has been the social philosophy of the citizens who constitute this organization in the city of Louisville? Is it possible to trace any developing social philosophy through the changing organization, program and policies of the society? Why has the socioty, which was originally partially promoted by ohurch groups become so completely independent of church leadership? Does this area of relationships indicate the possibility of future study? How is the membership recruited? To what extent are the mombers of the organization representative of the larger community? What contribution has the society made to social planning and legislation? As a member of the Community Chest, to what extent is the society dependent on the program and control of the Chest? Is the Family service Organization a relief giving agenoy? What is its relation to the public welfare program? With the extending programs of public assistance what services remain outside of relief giving for a private family society? In community planning does the agency use the neighborhood approach? What is the special contribution of the District Conferences? Do they offer an area for further study? What is the relation of the lay organization to the professional staff? To what extent is the support of the agency threatened by increasing specialization of the service? In the following chapters this study will attempt to find the answers to these questions. 
CHAPTER I

THE CHARITY ORGANIZATION MOVEMENT 
THE CHARITY ORGANIZATION NOVEMENT

The Charity Organization Society was one of many similar organizations that developed as a protest against the abuses of Poor Law administration and sought to deal with the causes of poverty. Basic to an understanding of the early Charity Organization Societies is a knowledge of English and American Poor Law.

The most important principle of the English Poor Law was that of local responsibility with the parish set up as the administrative unit. Family responsibility was expressed in the provision that certain kin had to assume responsibility, and to me日t the problem of drifting population, settlement was made a preroquisite for eligibility for aid. Other principles of the Act of 1601 that have influenced the history of both EngIish and American poor relief were the repression of begging, except when authorized; provision of employment as a means of assistance; provision for the care of those who were poor and unable to work; the setting to work and apprenticing of children and the free use of the house of correction for the idle and petty offender.

1. Material for this chapter is taken principally from Watson, Frank $D_{\bullet}$, The Charity Organization Movement in the United States, New York, The Macmillan Company, 1922, and B rockinridge. Sophonisba P., Public Welfaro Administration in the United States, Chicago, The University of Chicago Press, 1927, and from other materials listed in the Bibliography. Credit is due Mrs. Bernice Ellis for help in collecting this material. 
Many were the outgrowths and abuses that resulted from the English Poor Law of 1601 and subsequent amendments. Parochial responsibility led to confusion; the undifferentiated work house was set up in each parish; the apprenticeship of children led to all the evils of child labor; lack of any standards for personnel, and authority in the hands of overseers of the poor led to misuse of funds, mounting cost and increased pauperization. Protests lod eventually to the Amendments of 1834 as a result of the Royal Commission on the Poor Laws. The basic principles of these Amendments wero: national uniformity; less eligibility, the principle that a pauper should recoive less for his work than the lowest paid independent laborer; and the work house test, the principle that no able-bodied person should be given relief if he would not work.

Because these laws did not solve the problem of pauperism which the industrial conditions of the time were increasing, efforts at reform both public and private continued. In 1869, the Charity Organization Socioty of London was founded as the first society for organized cherity. The fundamental principles of the London Charity Organization Society, and other similar societies, can be traced to the founding by Saint Vincent de Paul of the Ladies of Charity in 1633 in an effort to change the mothod of treating the problem of poverty. Saint Vincent de Paul was opposed to begging and indiscriminate almsgiving and believed in friendly relationships between the rich and the poor, but his first attempts at friendly visiting or voluntary work among the poor were unsuccessful because the poople knew so little about relief giving. In the 18th century, 
numerous efforts, in addition to public reform, wero made by private individuals and groups to find a possible curo for pauperism. Examples of these were the Eberfield System in Germany of organizing poor relief in neighborhood councils and developing a technique of dealing with the problem of poverty; Count Rumford in Bavaria secured the cooperation of the whole community in his attack on poverty. Thomas Chalners in Glasgow believed people could aid themselves if given the opportunity. In England in 1796, Thomas Bernard, who saw help to the poor as personal service, founded the Society for Bettering Conditions and Increasing Comforts of the Poor. In London in 1805, the London Mendicancy Society was formed to help those in real distress.

With these earlier efforts as a background, the London Charity Organization society in 1869 had as its object and purpose the elimination of suffering from poverty not through the giving of relief, but through direction of it. The London Charity Organization Society showed what was true of other societies, that one of its greatest assets was the influence of the membership of its board of directors. When the Society began, it had no funds, no district committees. It had hope, which was fulfilled, to organize a central committee, and district committees in 211 parts of London which would organize charitable relief administration, serve as a clearing house in the district which did not come under the jurisdiction of the Poor Law, and cooperate with Poor Law officials to prevent overlapping of relief. One of the early principles was cooperation between public and private agencies; the private society was to promote real efficiency in other societies and to be the rival of none. 
Early public relief in the United States borrowed heavily, even copied, the form and methods of English poor relief with its principles of local and family responsibility and legal settlement. The early laws were calculated to discourage applications for aid. They reflected the impatience felt toward or disapproval of dependent members of the community who became labeled as paupers, and were cared for either in alms or work houses, were farmed out, or were given outdoor relief in their own homes. The latter was the form most questioned or frowned upon in the early days of poor relief in America. Public indifference, administration in the hands of minor local officials, and meager funds all led to pronounced abuses in poor relief. During the early 19th century, there was a slow withdrawal of certain groups from generalized care, beginning with the first state lunatic asylum in 1834, and increasing during the century as other groups were singled out for more special, though often inadequate care. Children were gradually, though not entirely, removed from the general almshouses; special institutions were provided for the mentally defective, the insane, and for the physically ill. Abuses of administration had become so marked in many large oastern cities that by the third quarter of the 19th century, two important developments occurred. In Brooklyn, all public outdoor relief was discontinued suddenly in 1878; Philadelphia took the same step the next year; and Baltimore, Kansas City, New York City, St. Louis, San Francisco, and Washington followed soon after. In this period came the Charity Organization movement with its emphasis on friendly visiting, individualization and rehabilitation.

$$
2
$$

2. Kurtz, Russell H., "Public Relief", Social Work Year Book, 1935. 
Prior to this time, private charitable agencies were usually restricted in their activities to meeting the needs of special national or religious groups such as the Boston Scots Charitable Society founded in 1657, and the Society for the Relief of Poor Widows with Small Children founded in New York in 1789. Such societies generally attacked the problem of destitution and were the predecessors of the Charity Organization movement in America. Another such society was the New York Society for the Prevention of Pauperism established in 1817.

The Charity Organization Society, founded in Buffalo in 1877, is usually credited with being the first in this country. There were at least a dozen family agencies, however, which were established at an earlier date, the first in 1810. These were originally relief rather than service agencies, consistent with the emphasis in the earlier period upon restraint and discipline of the poor, who were looked upon as undesirables to be punished or reformed or both. In 1840 , a reaction to this attitude set in, exemplified by the establishment in New York City of the Association for Improving the Condition of the Poor, which had as its objective a more humane personal interest in the needy. A system of visiting the poor in their homes was instituted in order to offer advice and encouragement as well as relief. At the time of the founding of the Association for Improving the Condition of the Poor, New York was faced with the problem of the destitute immigrant, and various national societies were founded to meet the needs of many of these families. Many of these societies had for their purpose moral objectives as well

3. Lund, Harold H., "Family Social Work," Social Work Year Book, 1939. 
as the relief of porerty and sickness, for public-spirited citizens were turning their attention to moral questions, temperance leagues, otc. The idea that people were in need because they were shift less, lazy and intemperate was predominate in this period. The achievement of economic independence, or the feilure to achieve it, was regarded as a matter of character. Basic in the concept of family service was the idea of selfhelp and the purpose of strengthening the capacity of the individual for self-maintenance. With this pivotal interest in character, it is readily understood how the concept of self-maintenance went beyond the limited view of the economic to include the planning and management of the whole life. 4

Interwoven with the moral objectives of these early societies was the desire to eliminate duplication of relief giving. In New York alone, lack of cooperation between the over thirty relief agencies resulted in indiscriminate relief giving with no home investigations and no relation to public service to the needy. From a committen organized to consider this whole matter, the Association for Improving the Condition of the Poor movement was founded by Robert $\mathrm{N}$. Harlley about 1842. The general principles of relief administration were: investigation of relief need; relief distributed by a district system of local workers and volunteөrs; eligibility determined by certain conditions, temporance, school attendance, etc.; the making of beggars and those who were willfully dependent less comfortable than the able-bodied worker. The Association

4. Libbey, Betsey, "Family Social Work," Social Work Year Book, 1937. 
for Improving the Condition of the Poor turned its attention to social conditions and agitated for improved housing, temperance leagues, gambling and lottery legislation, etc. The movement failed bocause the adminiatration of relief had become routine without help to the individual to better his physical and moral condition. Many associations which were established from the New York model did away with voluntary service and home visitation. There was not the cooperation between charitable societies, which was seen in the English Charity Organization movement to be the primary principle of effective work.

The Chardon Street Building, organized in Boston in 1872, was a more direct forerunner of the Charity Organization movement. It brought together official and private relief agencies under the same roof in order to facilitate consultation and clearance of cases, and it laid particular stress on registration of elients and on voluntary service in relief administration. 5 In 1873, because of the unemployment problem which followed the industrial depression of that year, many societies were founded to help the needy and many took the London Society as their model. Some societies did not follow the model very closely. The immediate cause for organization of the movement was the industrial depression following the panic of 1873, and the underlying cause was the human need to "help thy neighbor" as a good citizen. Because of abuses in public welfare during this period, there was discontent in the mothods of handling public outdoor relief. There was also discontent with the indiscriminate overlapping of private charity.

\footnotetext{
5. Lund, Harold H,, op. cit.
} 
The first experiment in America was in Germantown, Pennsylvania in 1873, but Buffalo, in 1877, was the first large eity to organize a Charity Organization Society. The founder, the Reverrend S. H. Gurteen, who had been associated with the London Society, modeled the Buffalo Society after its principles. These fundamental principles of organization were used as a guide in the establishment of the society in Louisville in 1884. Other cities soon followed the Buffalo example. The Philadelphia Society for Organized Charity was founded in 1878 , the Boston Associated Charities in 1879, the As sociated Charities of Detroit in 1880, and the New York Charity Organization Society in 1882. By 1892 there were ninety-two Charity Organization Societies in the United States, most of them, like the Buffalo Society, motivated by a desire for order and economy in dealing with the problem of poverty.

The fundamental principles of the Charity Organization movement were investigation, registration, cooperation and friendly visiting, and they became the first scientific criteria of the administration of relief giving and treatment of human relationships in America. The aim of this movement was to aid in the elimination of the causes of poverty by re-adjustment of family and individual problems and by adjustment of social conditions which were the causes of poverty. The methods used to carry out this aim were the coordination of the various resources in the community and community organization through education in adequate principles of relief. The "case method" was the principle by which these societies endeavored to carry out their aims. It was treatment of the individual problem to help the individual solve his own problem. 
It might involve financial help, but might also include giving advice, securing medical aid, vocational guidance, or one or more of the many ways to holp an individual becomo adjusted. It included "social diagnosis," the method of defining, after careful investigation, the problem which the individual presents, and "social treatment," the plan of treatment to be given in helping torard a satisfactory adjustment.

The function of the early societies varied but generally was on the basis of carrying out the principles of the cese method. Cooperation among agencies was the essence of treatment. The morement was proclaimed for its efficiency in reducing the relief load and in the transferral of it from public to private control. 6 At each stage in its development, family casework has been influenced by and has reflected in its practice the philosophy and seientific theories of the period; but concern with character and how it is evolved through the integration of the inner and outer forces has remained constant. In the early stages, character was regarded as developing from individual opportunities for education, work, recreation, health and spiritual life; the voluntary visitors, therefore, had as their aim the strengthening of family life in the marginal economic group through securing these opportunities one by one for families and heartening them in their use. Help in securing work, providing special training, enabling children to stay in school, securing the services of private physicians, introducing children and adults to settlement clubs and classes, and strengthening ties with

6. Lund, Harold H., op. cit. 
the church -- such were the first services of family societies. Gradually there was a growing interest in the causes of poverty and in handicapped and dependent persons in their own right. Volunteers began to give way to professional workers in the decade from 1890 to 1900. Training courses were started in the Brooklyn Society in 1891, and the first summer courses were offered some years later by the New York Charity Organization Society. In this period, two main lines of interest began to take definite form: one, an interest in the systematic study of the individual, in which the Philadelphia Society for Organized Charity, later the Philadelphia Family Society, under Mary Richmond, took leadership; the other, a concern with underlying social conditions, in which the lead was taken by the New York Charity Organization Society under Edward T. Devine. While both interests continued to be characteristic of the field, the tendency gradually developed to relinquish to other agencies, many of which had their origin in the charity organization movement, those activities which did not call for direct service to individuals and families.

The Louisville Charity Organization Socioty was founded at the beginning of the period in which the movement was extending throughout the country. Its principles reflected those of the eastern societies, but like the other societies, it also was influenced by conditions in its immediate environment.

7. Libbey, Betsey, op. cit.

8. Lund, Harold H., op. cit. 
Although the English Poor Law of 1601 greatly influenced the development of poor relief in the United States, Kentucky was not influenced as much by it as were the New England states. Kentucky patterned its law on the Virginia Act of 1785, which transferred poor relief responsibility from the churches to overseers for the poor. It was the duty of the county courts to provide for the support of the paupers of their counties. There was no legal obligation, however, on the county to pay for the support of its paupers. A pauper was defined as a person who was found by a jury to be a "pauper, idiot, or lunatic." Parental responsibility was patterned after the Elizabothan Act, but there was no mention of authority to force parents to support children, or children to support parents, as was true in some states. The Kentucky Poor Laws set up no residence requirements (settlement laws) except that if a person was committed to a state institution and was not a legal resident of the state, he would be returned to his legal residence. The Act stated that a pauper could not be brought from another state or from any county into another.

The State assumed responsibility for public welfare in various ways. In 1820, land grants were used for relieving destitution. State agencies for the care of "wards of the State," insane, deaf and blind, feeble-minded, and delinquents, were developed with many of the evils of complex administration and defects in organization of other states. The Kentucky Institution for the Deaf and Dumb, started in Danville in

9. Sunley, Emil MoKeo, The Kentucky Poor Law, 1792-1936, University of Chicago Press, $19 \overline{38 .}$ 
1822, was supported by private donation as well as State money. The Kentucky Lunatic Asylum, established in Lexington in 1822, was under the administration of a steward, at first appointed by the governor and later appointed by commissioners. Care of pauper ldiots was made by provision for cash allowances, though these were inadequate and poorly administered. It was not till 1936 that a state Department of Public Welfare was established.

In Louisville, there were fow outstanding public and private charitable organizations and institutions in existence prior to the establishment of the Charity Organization Society. Private charities and institutions were founded chiefly by religious or national groups, such as the Scotch Benevolent Society, founded in 1854, and the Protestant Episcopal Orphan Asylum, founded in 1826. Like other cities, as Louisville grew, many small societies came into existence without coordination, and many were formed with a purpose which included giving relief to the destitute. In 1836, the first Louisville Charity Society was founded with a staff of ten volunteer visitors for the purpose of "feeding the hungry, clothing the noked and mitigating the conditions of the bereaved sufferers under the severe distress of poverty." 10 During this same period, several public institutions were established and maintained by the City of Louisville. In 1817, the City Hospital was incorporated. The Home for the Aged and Infirm, then called the Almshouse, and the Eruptive Hospital were started during

10. Johnston, J. Stoddard, Memorial History of Louisville, Chicago and New York, American Biographical Publishing Company, 1896. 
this period. These and other city institutions were supported out of the general tax fund and were under the Board of Safety. There was no system of outdoor relief except in the rinter when the city distributed a limited supply of coal through the Mayor's Office, or such agencies as he designated. A series of the city charters gave recognition to the need for public assistance. In the City Charter of 1828 , the Council was given the power, as well as the duty, of erecting or procuring a suitable building in which the indigent poor would be comfortably provided for at the expense of the city. The City Farm, later called the Forkhouse, was built to acconmodate the poor, the sick and the petty offender, showing how closely the ideas of that period followed those of two centuries earlier in England. The Charter of 1851 gave the General Council power to levy a tax of five mills per one hundred dollars assessed property value, in order to provide the destitute poor of the city with supplies of money, wood, coal or provisions. In 1852, the Almshouse, which had been housing numerous dependent children, was given power to apprentice male children up to the age of 21, and female children up to the age of 18, without consent of their parents or guardians. In 1856, it was ordered that admissions to the Almshouse be by permit only, to be issued by the trustees to one who had lived in Louisville for at least one year. This is the first mention of residence requirements. Apparently, people who had just come to Louisville had been in the habit of receiving freo care at the Almshouse, and the trustees found it necessary to require "tickets of admission." 11

11. Strong, Margaret K., "Public Welfare Administration in Louisville, Kentucky", Louisville, 1935. (Unpublished) 
Throughout the latter quarter of the 19th century, one of the influences in the development of both private and public welfare was the National Conference of Charities and Corrections, founded in 1873. and changed to the National Conference of Social Work in 1917. Early Conference programs reflect the concepts and practices current at that time, which were the result of the thinking and experience of public and private leaders and which in turn influenced others. The period of 1873 to 1900 was one of general discussion and orientation. The first fifteen years of that period were devoted largely to basic problems of charities and corrections and tothe beginning of public welfare organization and work. The second part of the period was marked by the promotion and idealism of the pioneers, by the development of private social work, and by much greater interest on the part of the public, manifested by an increase of gifts and contributions. The close relation between charities and the church was evidenced by the fact that the first four presidents of the Conference were clergymen. The period of 1895 to 1900 marked the turning toward technical discussion and cooperation with public social work. Subjects of discussion during this entire period indicate changes in concept, philosophy, and practice. From 1879 on, there was much discussion of the classification of paupers and prisoners; from 1894 through 1899, discussions of dependent and neglected children centered around the ovils of the Almshouse and the value of boarding home care, but by 1899, there were warnings against the evils and dangers of unsupervised placing out; the "new" public outdoor relief was discussed as early as 1891. The conference began as a 
conference primarily for public officials; pace setting of private social work in later years led to the dominance of private social work and accentuated the trend toward making private social work the chief medium for relief, especially in the eities. The proceedings of recent years are measures of the step by step evolution of ideals and standards, and show a trend on the part of public welfare agencies to adopt the standards of professional social work as represented by the National Conference. 12

In Louisville, with the increase of population, the increased number of charitable societies and inadequate public assistance, there was no central organization or cooperation between societies. Relief was being duplicated and was inadequate to meet neөd. A group of influential people banded themselves together in 1883 with the idea of establishing a Louisville Charity Organization Society to act as a clearing house for societies which would administer relief and to prevent duplication by investigation of all relief applicants. In forming the society, the New York Charity Organization Society was consulted, and the basic principles of the charity organization movement in America became the principles of the Louisville Society.

The charity organization movement in America was organized "as a protest against un-coordinated and unintelligent relief giving." At first, the movenent was unpopular. Because of the basie principles set forth, however, the public was gradually won over. These basic princi-

12. Odum, Howard W., Chapter XXIV "Public Welfare Activities" in Recent Social Trends in the United States; Report of the President's research committer on social trends, New York and London, MeGraw-Hill Book Company, 1933. 
ples included: "no central relief fund; no indiscriminate public assistance; thorough investigation of all applicants for relief, an act of deterrence of fraudulent claims." The movement was against political corruption. The private society aimed to discover the causes of poverty and fostered cooperation between individual givers and distressed families. 13

13. Richmond, liary E., The Long View, pages 31-34, New York, Russell Sage Foundation, 1930. 
CHAPTER II

THE CHART TY ORGANIZATION SOCIETY OF LOUISVILLE

$1883-1907$ 
THE CHARITY ORGANIZATION SOCIETY OF LOUISVILLE - - 1883-1907

A. ORGANIZATION AND STRUCTURE

Recorded material does not satisfactorily indicate either the immediate events that led to the founding of the Charity Organization Society or the steps followed by those who took part in its formation. The Tenth National Conference of Charities and Corrections was held in Louisville in 1883, and it seems likely this meeting may have given direction to citizens who were disturbed by lack of cooperation and duplication among the several agencies in the city. In a speech before the Ministerial Association of Louisville on January 5, 1885, Colonel Andrew Cowan, of the Central Council, stated, "Wo organized at the instance of a minister, though no minister is a member of our central Council." 1 The Twentieth Annual Report of the Society on October 1 , 1903, mentions as "first friends in the formation of our Society" the Reverend Edmond T. Perkins, F. J. Pfingst, and David P. Faneds. The same report indicates that work toward formation began in September, 1883; the first Central Council was elected January 21, 1884, holding office to October 1, 1884, and the charter was granted May 9, 1884. The eharter lists the following who banded together to form the society:

"Be it enacted by the General Assembly of the Commonwealth of Kentucky

That P.Joyes, John Callahan, N. G. Rogers, C. B. Seymour . W. T. Rolph, John H. Weller, W. C. Hall, Andrew Cowan, F. D. Carley, Garvin Bell, George

1.

"The Courier-Journal," January 6, 1885. 


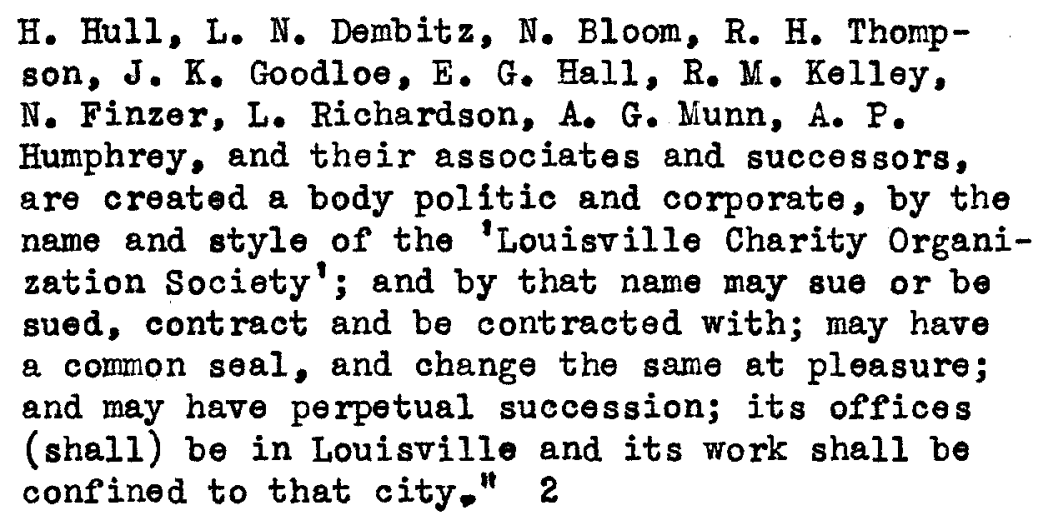

Objects and Principles

The Constitution sets forth the fundamental principles of the society and indicates how closely the founders followed the general prinoiples of the charity organization movement. The development of the society indicates these objects and principles expressed the philosophy of the community and its leaders throughout the entire history of the Charity Organization Society. The principles as expressed in the constitution wero:

"1. Every departrent of its work shall be completely severed from all questions of religious belief, politics, and nationality.

"2. No person representing the society in any capacity whatsoever shall use his or her position for the purpose of proselytism or spiritual instruction.

"3. The Society shall not directly dispense alms in any form." 3

2. "An Aet to Incorporate the Louisville Charity Organization Society," Section I, May 9, 1884.

3. The Constitution of the Charity Organization Society of Louisville, Kentucky, Article II. 
The principle of coordination among existing charitable organizations and institutions to the end of obviating duplication of relief giving, the suppression of begging and the providing of work for employables, all principles of the nineteenth century charity organizatiom movement, are clearly evident in the objects of the society:

"1. To form a center of inter-communication between the various churches and charitable agencies in the city; to foster harmonious cooperation between them, and to check the evils of overlapping relief.

"2. To investigate, and without charge, the cases of all applicants for relief which are referred to the Society for inquiry, and to send the persons having legitimate interest in such cases full reports of the results of the investigation. To provide visitors who shall personally attend cases needing counsel and advice.

"3. To obtain from the proper charities and charitable individuals suitable and adequate relief for deserving cases.

"4. To procure work for poor persons who are capable of being wholly or partially self-supporting.

"5. To repress mendicancy by above means.

"6. To pronote the general welfare of the poor by social and sanitary reforms and by the inculcation of habits of providence and self-dependence. To encourage the establishment of such provident institutions as shall tend to the physical, moral and intellectual improvement of the poor." 4

Membership

The Constitution provided that persons who made an annual contribution to the society were members of the society. Recognition of

4. Constitution, Article II, op. cit. 
this service was provided by publication of membership lists in the press and in the annual reports of the society. Incentive to membership was the provision that no nember of the society was entitled to rote at any general meeting or election of the council or ras entitled 5 to election to any office who had failed to pay annual dues. Provision was made for various kinds of membership: nembers of district committees; annual members, those who paid an annual subscription to the funds of the society; ex officio members, including the Mayor, Chief of Police, health officers, Superintendent of the Almshouse, etc.; and honorary members, the presiding officers of all charitable societies in 6 the city.

Because of duplications in printed lists, it is difficult to ascertain the exact number of members. The first report lists 107 members and contributors; membership reached as high as 290 in 1897. The number remained fairly constant after the first few years, varying from around 180 to 275. A study of these lists reveals the constancy with which the names of mombers of Louisville's "first families" and old firms appear and the comparatively few additions to the list from year to year. This group seems to have been the backbone of participating support for the society. Constitution

The Constitution provided many tasks for citizens chosen to do the work; in fact, one might say that until the latter years of the

5. The Constitution, Article VII.

6. Ibid., Article III. 
society, the laymen were the society, so little part did the paid employees play in the derelopment of the society.

At the center of organization was the Central Council which functioned chiefly through its Bxecutive Committee. Responsible to and functioning through authority delegated by the Central Council were the standing and special committees, the District Conferences and Friendly Visitors, and other volunteers.

The management of the society was vested in the Central Council, who generally determined all questions of policy. The Council consisted of twenty members of the society elected by ballot at the annual meoting, the chairman and secretary of each District Committee, ex officio mem7 bers, and members especially elected. Regular meetings were held month1y, and meetings might be called by vote of the Council, or by any officer with the concurrence of three members and after three days' notice in writing. The Council was given power to make by-laws as it might deem necessary and might also alter or suspend same. The active responsibilities of the Council were carried on by its Executive Committee, composed of officers of the Council. Responsibility for all property owned by the society, with full executive and directory power over the business of the society, subject to the approval of the Central Council, was rested in the Executive Committer. Specialized responsibilities were delegated under the Constitution to the following standing comittees appointed by the president:

7. The Constitution, Article IV.

8. Ibid. 
The Finance Committee was given the duty of auditing the accounts and vouchers of the Financial Secretary and Treasurer, and devising and carrying out the best methods of raising money to carry on the work of the society.

The Nembership Committee was charged with the duty of extending and making general the membership of the society.

The Publication and Iibrary Committee was expected to provide for publications felt to be necessary for the work of the society, and was charged with seeing that the objects and work of the society were regularly brought before the public in the daily papers, and with the purchasing of such books, magazines and papers as were felt to be suitable in establishing a library.

A Cooperation Committee was expected to devise and carry out the best mothods for bringing into active cooperation with the society all the churches, charitable organizations, civil and police authorities in the city.

The Employment Committee was given the duty of devising and carrying out plans for securing work for the needy in factories, families, or in the country, and was ernpowered to see that the labor test was carried on under the principles of the society. To carry out these responsibilities, it was empowered to raise noney and to give such encouragement as might be necessary.

The Bendicancy Committee was expected to se日 that investigation tickets we re placed in every business house and family, was asked to have professional beggars prosecuted or confined, and to devise and propose plans for suppressing mendicancy and helping the mendicant to become selfsupporting.

The Legal Committee was expected to advise the agents, officers, and committees of the society upon questions of law referred to it; direct the agents of the society in bringing beggars and impostors under the penalty of the law; aid in the commitment of children to the proper institutions, and defend or prosecute cases in which the society was concemed. This comitteo was further expected to prepare any nocessary legislation to effect the purposes of the society.

The District Conferences Committee was expected to propose and establish such District Conferences as the work of the society demanded. 9

9. The Constitution, Article IX. 
The Constitution provided that the Central Council should designate the districts of the city and that in each district or combination of districts there was to be a District Conference, sometimes referred to as District Committee. Each Conference was to bo composed of five or more members, including the society's Agent, Friendly Visitors, officers of public and private charitable organizations, and ministers of churches within the district, persons elected or employed by the Conference and all other members of the society Iiving or working within the district. The original Conference in each district was appointed by the Central Council with subsequent vacancies filled by the Conference with the approval of the Council. The Conference elected its own officers, and subject to the control of the Council, was expected to manage the work of the society within its district and to appoint and remove Friendly Visitors assigned to cases. The Conferences were empowered to make by-laws for their own goverment and to adopt any measure which they might deem expedient, provided such by-laws and moasures did not conflict with the Constitution of the society or with its By-Laws, and provided same should be submitted to and approved by the Central Council. The Conference was not allowed to raise funds for its own separate use.

The work of the District Conferences, as the founders visualized it, is outlined in the Constitution as follows:

"1. It shall be the duty of the Conference to see that every applicant for relief within the district is thoroughly investigated.

"2. To send a friendly visitor to each poor family. 


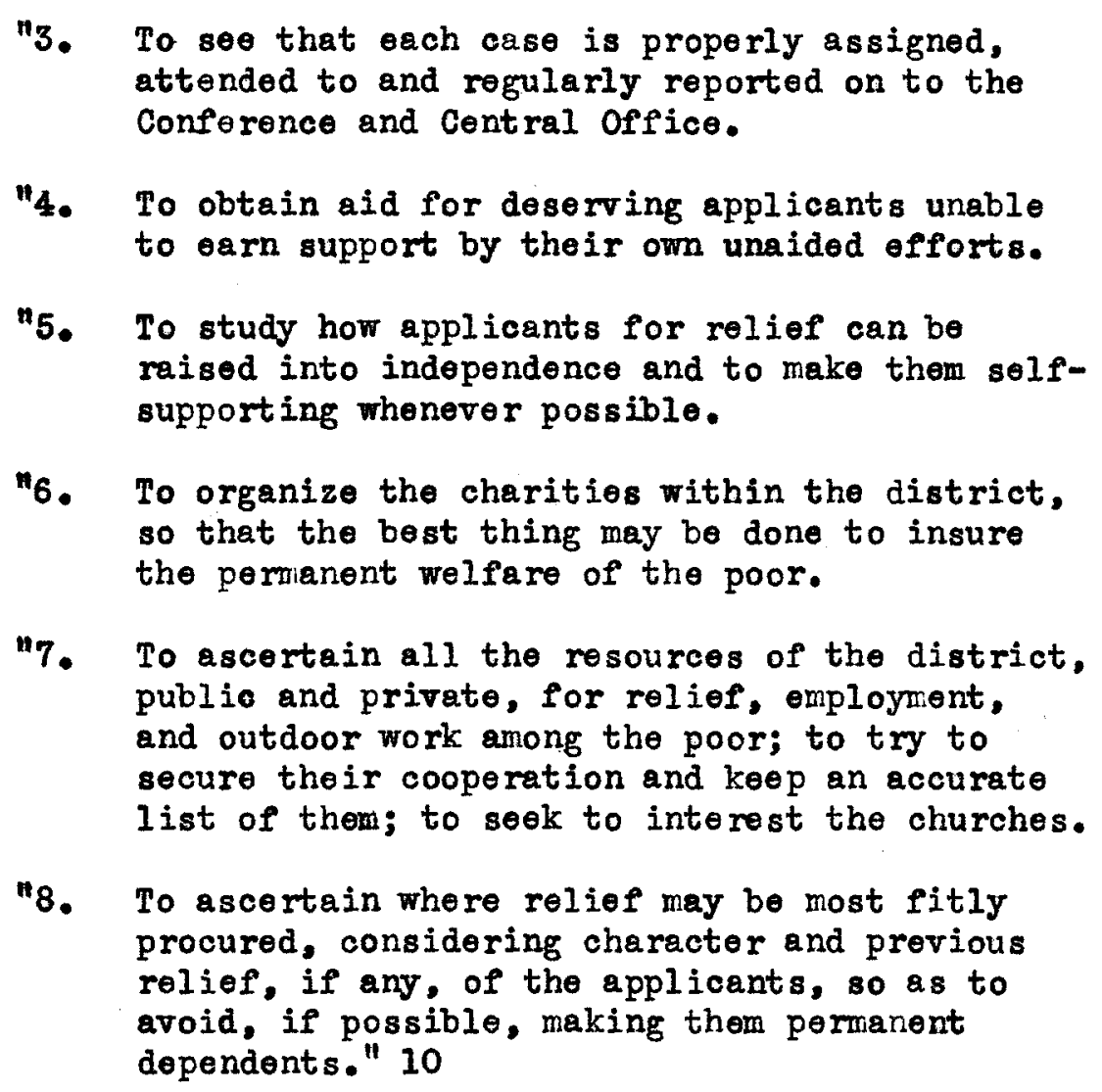

The Distriot Conferences were expected to meet at least monthly for consultation. After each Conference was effectively organized, the following committees and sub-committees were to be appointed as they could be successfully directed: Vagrancy; Employment, two branches, one for men and one for women and children; Provident Habits; Loans, Care and Education of Children; Industrial Training; Claims and Legal Protection of the Poor; Hygiene, Hedical Charities, and Condition of streets; Improvement in Homes of the Poor, and Domestic Economy. These com-

10. The Constitution, Article XII. 
mittees were expected to study methods of dealing with each subject and 11

to deal with cases neoding special treatment.

Founders of the society visualized that the largest group of

laymen in the organization would be those designated as Friendly Visitors. The principles of the charity organization movement and the experiences of other Charity Organization Societies were followed closely in planning for and appealing to the first group of Friendly Visitors. In organizing the group, use was made of a re-print of an article on the duties of Friendly Visitors by Mrs. Charles R. Lowell, of the New York Charity Organization Society. This pamphlet apparently was given wide distribution and gave the following interpretation:

"The Louisville Charity Organization Society has divided the oity into districts of convenient size and wishes to form in each a body of visitors to carry to the poor, by friendly hands, those cocial influences which in many cities have proved so effectual in the permenent improvement of their condition. They will not be called upon to bestow temporary relief; sufficient provision for that already exists, but it only skims the surface of the troubles which environ the depressed. Much of this relief is misapplied, and the visitors can advise to its judicious bestowal; but, better than this, they will be asked to go to the poor as neighbors and to stand by them patiently as friends; to discover and remove causes of their depression; to give them sympathy, counsel and encouragement which they need; to communicate the energy, hopefulness and ambition which friendly intercourse alone can give.

"The wise visitor may suggest how to improve the health of the family in matters of ventilation, personal and home cleanliness, clothing, diet, care of the children and the sick; how to improve their homes, or to move to

11. "Rules for District Committees, "The Louisville Charity Organization Society, February, 1884. 
sunnier and purer quarters; how to find work and aid to secure it; how to economize and to practice thrift and foresight; how to overcome habits of intemperance and idleness; how to train the children in ways that will form them into good men and women. The visitor may also advise the poor how to avail themselves of the Dispensaries, Saving and Provident Societies, and all the other benevolent facilities offered to supplemont their small means; and may earry to them the cheer and encouragement which comes from realizing that they have a living union in a great brotherhood of man. " 12

This quotation was sent out on a form on which the volunteer was to declare his or her intention and willingness to so act, and to indicate the location in which cases were preferred. Special emphas is was given to the statement by Mrs. Lowell that "the best success of our Charity Organization Society will depend eventually upon the devotion and wisdom of the members of our District Committees and their Visitors." Sometime during the first year of its organization, the society published for the use of the Friendly Visitor the "Hints and Suggestions" used by the Charity Organization Society of Chicago, Illinois, and requested the attention of the Visitors to these hints, the "carrying out of which is essential to the uniformity and effectiveness of the society's work." These suggestions left the specific treatment of each case to the judgment of the individual visitor, but left no doubt as to the philosophy that was to guide the work:

"1. Conduct your intercourse with the poor on the basis of honest, simple friendship. Any action of condescension or patronize is not only wrong in itself, but is sure to do harm by preventing the visitor from getting into the right and natural relations with the poor.

12. Lowell, Mrs. Charles R., "Duties of the Friendly Visitor," Charity Organization Society, New York City, re-printed by Louisville Charity Organization Socioty, 1884. 
"2. Never state the object of a visit as being to se日 whether any RELIEF is needed. If it is known that you have the absolute bestowal of alms... your influence as a friend will inevitably become weakened and finally will cease to exert any power for good whatsoever.

"3. Beware of allowing importunity or the excitement of a momentary sympathy to obtain from you assistanco which your judgment disapproves.

"4. No relief should be given by the visitor.

"5. Be on your guard against encouraging idleness, improvidence, or grosser misconduct, directly or indirectly. Injudicious almsgiving to the family of a drunkard, dissolute, idle or shiftless person will invariably do more ham than good.

"6. The best method of assisting deserving people when in need is to help those who are able to find employment.

7. Do all you can to encourage formation of PROVIDENT HABITS. Urge the very poorest to lay by something, however little, in a Saving Bank; explain the nature and advantages of these institutions, and if necessary to, offer to go with them when they make their first payment.

"8. Whenever you perceive a want of personal cleanliness, or a neglect of proper ventilation, take an opportunity of advising and even urging the importance of improvement. These points are so essential to health that it is always advisable to keep urging the matter until a change is mado.

"9. Keep those whom you visit informed of their rights and duties as TENANTS, and if you observe any serious defects in their houses or neighborhood immediately cell the attention of the District Agent to the fact.

"10. Where families are contaminated by vicials surroundings urge them to move.

"11. To ascertain the best course to pursue, refer to the District Committeo.

"12. When you can do so without offense, communicate any simple recoipts for cooking, suggestions for 
economic housekeeping, and the least expensive and most durable axticles of clothing

"13. Aroid anything like dictation in suggestions. Do not offer advice in the presence of neighbors.

"14. Encourage parents to send their children to school regularly.

"15. Endeavor, in so far as lies in your power to foster the 'pride of the homes' by helping to make the dwelling bright and cheerful, with the gift of such articles as cannot possibly pauperize, but on the contrary will elevate and refine the tastes.

"16. Listen patiently to any statements that may be volunteered respecting the worldly joys or sorrows, or ambitions of the family you visit, but avoid even the appearance of inquisitiveness, and never repeat to others anything that you have thus learned..." 13

The Visitors were warned against the "great danger to be avoided" in the formulation of dependency habits in the receiving of temporary financial assistance. It was recognized that the suffering and distress which the unemployed person felt was real, but that there were many chances of doing him a real injury by giving alms. The Visitor was urged to consider as her aim some means of helping families to gain permanent independenoe. "The great lesson we want to teach people is to depend on themselves, and not to look to any one for anything excopt friendly advice and counsel." It was considered injurious for the wife of an able-bodied man to work. "A woman's time should be spent

13. Gurteen, Reverend S. Humphreys, M.A., Organizing Secretary, Chicago Charity Organization Society, "Hints and Suggestions to the Visitors of the Foor," re-printed by the Charity Organization Society, Louisville, 1884. 
in the home. Children of decent and industrious mothers often grow up to be vagabonds because their mothers left them to work. If the mother is a widow, charity may help her to guard her children." 14

\section{B. FINANCE}

The Central Council quite early found it impossible to hold to the society's purpose of dispensing no relief. Whenever agency funds were depleted, or there was an emergency, a conmittee of the Council undertook to raise the necessary funds. As it became apparent that there was a yearly need for funds to meet emergency needs before a family could be referred to another agency, a Special Benevolent Committee was created by 1892 to raise and supervise the dispensing of funds which were kept separate from the regular budget of the society. The method of raising funds was by personal solicitation, in which the committeo drew in other members of the Council to assist, by appeals in the press and distribution of leaflets. Temporary sub-committees continued to be appointed whenever there was a need for funds other than those considered solely for emergency cases, and both types of committees always seemed to meet with success in raising whatever was needed. Various individuals on the Council periodically gave service by writing the publioity used by the Benevolent Committee or temporary committees. This raising of funds was separate from the annual appeal and solicitation by the Memberwhip Committer for members, those who made an annual plodge of at least five dollars to the society. In addition to publicity as to the

14. Lowe11, Mrs. Charles R., op. cit. 
annual membership, lists were similarly published of those who made additional gifts, those who answered special appeals and those who gave comodities, particularly coal, clothing and baskets of food. Such publicity no doubt did much to encourage such participation and as has been indicated, the supporting nembership was a considerable and fairly constant group.

Two laymen made very large and permanent gifts to the society. In 1893, Mrs. Mary Richardson Belknap, in recognition of the work and interest of her husband, William Burke Belknap, in organized charity, gave to the society the building which is still the setting for the agency. The same year, Mr. R. A. Robinson gave $\$ 5,000,00$ for the erection of the Wayfarers' Lodge, which was built under the direction of the Building Committee of the Council, created at that time. This committee raised funds for equipping the Wayfarers' Lodge.

\section{PROGRAM AND POLICIES}

With organizational plans outlined in the constitution, the society began its chartered work in 1884.

The extent of newspaper interpretation during the early years may be an indication of the many programs undertaken and the prestige of at least some of the citizens identified with the society, but is probably also due to a natural "smell town" interest in every possible item of local news. The detail with which announcements of work of the society were reported and the editorial support of the principles and activities of the organization are evidence of confidence in the large group of laymen who were so actively engaged in the work. Interpretation was greatly 
facilitated by the work of the Publication Committee, which was particularly active during the first year. To carry out its duty of acquainting the people of the city with the aims of the organization, the committee had printed and distributed a large number of forms, pamphlets and circulars, the most important of which were: "Objects of the Society," "Constitution and By-Laws," "Rules for District Committees," "Duties of Visitors to the Poor," "Hints to Friendly Visiting," notices to employers, and pads of investigation tickets. On June 1, 1885, the Publication Committee had re-printed and gave wide distribution to a sperch by Robert Treat Paine, Jr., Esq., President of the Boston Associated Charities, entitled, "How to Repress Pauperism and Stroet Begging." The committee continually attempted by personal contacts to increase the membership of the society. Relations with Other Agencies and Institutions

To carry out its aim of cooperation among churches and charitable organizations, the Central Council, while continuing through printed appeals and personal contacts to sell the idea to both groups, made an earnest effort to draw the churches into the movement. The first report of a conference between the Central Council and the ministers of the city "in regard to the best plans for relieving the poor" is found in "The Evening Post" of December 26, 1884. Attendance and interest of the ministers was small. Apparently, other efforts had been made, for the First Annual Report indicated that by October 1, 1884, forty-six churches, seven charitable societies, and six institutions were cooperating with the society. Another attempt was made January 5, 1885, when 
a committer of the Council met with the Louisville Ministerial Association. Some progress in meeting the fear of the ministers that the charity organization movement would mean the removal of charity work from the churches seems to have been made. At this meoting, the ministers moved that plans of the society be made known to each church and that Friendly Visitors from each church be appointed by the pastor. 15 Periodically the Central Council noted progress in attaining its aim of cooperation, but the frequent pleas for cooperation, in the. press and in the annual reports, indicate occasional ovidence of lack of support by other charities and institutions and a general disappointment in attainment of what the Council felt was the cooperation necessary. This main theme was expressed variously each year in the annual reports but followed the general lines of the statement in 1886 of the need for cooperation "to bring into associated effort the whole array of benevolent agencies for the relief of the poor......to save what is given to the impostor and bestow it on the worthy poor, rid the community of paupers and make the poor self-supporting". 16

Attempts to gain cooperation were not limited to charities and institutions, for the Central Council was active in interpreting the same principles of cooperation and investigation to city authorities. The Council frequently published communications describing impostors who recoived relief from the city and asserted the police did not make

15. "The Courier-Journal," January 6, 1885.

16. Third Annual Report of the Charity Organization Society, Louis ville, October 1, 1886. 
adequate investigations. During 1885 and 1886 , there was frequent mention in the press of conferences of the Society's President, Randolph Blain, with the Nayor and Chief of Police to work out better mothods of distribution of city coal and to urge against advertising that freo coal was being given away. "The Courier-Journal" reported July 28, 1886, that a committee of the Council met with the Mayor to attempt to bring about more coordinated efforts to suppress streot begging. Other efforts were made to gain the Mayor's cooperation in meeting the problem of paupers' being sent or "shipped" to Louisville, particularly from Cincinnati. The philosophy of the men who made up the Council is revealed strikingly in an account of thoir moeting on April 26, 1887: 17 "Almost the entire afternoon was taken up in discussing
the vagrant question. Mr. Seymour thought the New
York vagrancy law was evidently a panic law and too
severe. Mr. Blain spoke of the English law, but it was
considered too cruel for a republican people. Mr.
McDonald related the experience of Lexington, Virginia,
and said the chain gang was the best remedy for tramps
and would be a great benefit to the states. A com-
mitter was appointed to confer with the Chief of Police
to a rrange to rid the city of such characters. Mr. Sey-
mour and the legal comittee will continue to consider
the vagrant question and report as to the advisability
of additional law, it being generally thought there is
enough law if it is enforced." Four days later a letter was sent to the Chief of Police and publicized recalling to him that an ordinance of June 11,1882 , defined vagrancy and provided that vagrants should be arrested and fined $\$ 20.00$, and recommending that this ordinance should be rigidly enforcod. The letter also called attention to an ordinance of 1853 in reference to the intro-

17. "The Courier-Journal," April 26, 1887. 
duction of persons into the city, which provided for punishment by fine for those disregarding its provisions, and urged its strict enforcement. ${ }^{18}$ similar action was taken by the Central Council in working with the Commissioners of Public Charity to arrange more satisfactory mothods for endorsement of charity drug prescriptions.

A real test of accoptance by the community and other organizations of the society's principles was offered by the tornado disaster of 1890. Three of the original nembers of the Central Council were members of the Board ofTrade Relief Committe日, one, Mr. W. T. Rolph, acting as cheirman. In addition to these men, the services of the Society's two paid Agents, and a group of the Friendly Visitors were "roquisitioned" as investigators. So successful was this demonstra-

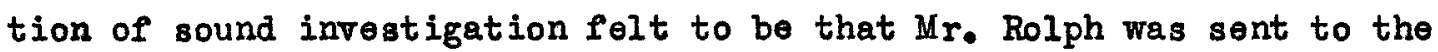
National Conference of Charities and Corrections and filed a report, "The Tornado Work of the Board of Trade Relief Committee of 1890 ". 19

Patterning after the work during the tornado, the Council during the flood of 1907 worked closely with the Citizens'Flood Committeo of the Board of Trade and the Comerical Club, and the Women's Emergency Association, mado up of representatives of many philanthropic bodies.

The Central Council came out of the experience of the two severe winters of the panic of 1893, when duplication of relief giving was apparently wide spread, with the strong conviction, which was given con-

18. "The Evening Times," April 30, 1887.

19. Seventh Annual Report of the Charity Organization Society, Louisville, Ootober 1, 1890. 
siderable publicity, that some individual or society should be charged with distribution of all charity coal. They offered the full use of the society's office and its records in such a plan. The efforts of the Council apparently were of influence, for the liayor on February 3 , 1896, sent a letter to President Blain turning over the distribution of city coal to the society. District Conferences and Friendly Visitors

The first step of the District Conference was to bring the objects of the society to the attention of every pastor in the district, and before every, charitable agency. In interpreting the services to be offered by the society, emphasis was placed on the primary object of the society, the "social and moral elevation of the poor," and on the secondary object, "through complete organization of all the charitablo societies, cases could be investigated to eliminate waste and pauperization of the poor." 20

The Conferences reported monthly on a stated form the work of the district to the Central Council. Although one of the society's two paid Agents was assigned to each District Conference, all correspondence. and information about clients was sent out in the name of the District Conference, an indication of the philosophy that the laymen were really the organization and only ernployed the small staff to do some of the detailed work for them.

20. Joyes, Patrick, President, Charity Organization Socioty, Louisville, Letter to the officers of Charitable Societies and Institutions, February, 1884. 
By the end of the second year, some District Conferences were in active operation and had organized themselves into all the comittees provided for in the Constitution. Efforts were made to keop the close cooperation of the churches. A letter was sent to each church inviting representatives to be on a Conference. The Central Council, in reporting on the Conferences for the year 1884-85, stated: "Our District Conferences are composed of men and women who earnestly labor to help the poor..... Their wisdom in determining the best methods of relief for each case and their zeal in laboring to secure the aid that has been thought advisable cannot be too highly praised." Friendly Visitors were being assigned by the District Conferences, but apparently there had been insufficient response to the appeal for Friendly Visitors, for the Central Council again appealed for a large number.

By October 1, 1886, nine District Conferences were fully organized and in active operation. Each Conference dealt only with cases residing in its district, an interesting analogy to the old English parish responsibility. That considerable difficulty had boen encountered and that early plans did not immediately result in successful participation is evidenced by the section of the Third Annual Report devoted to District Conferences.

"Under the Buffalo system originally adopted by this Association, the city was divided into four districts. In each district, there was a committee of thirteen business men, who engaged an Agent, opened an office, and performed the

21. Second Annual Report of the Charity Organization Society, Louisville, October 1, 1885.

22. Third Annual Report, op. cit. 
work of tho society within the district. It was soon found that the expense of so nany Agents and offices was too great for the income of the Society and that two Agents might do the work, so the four districts were consolidated and two committees appointed. In this way the work of the society was conducted until the spring of 1886.

"At first the committees were selected from good men living throughout the district. It was soon found that those living at distant points did not attend, and that a bare quorum could at any time be secured. Then new men were chosen, living nearer, and then adjacent to the district offices;, but this failed to secure regular meotings or a quorum. When the meetings were held, the committee men would hear reports of persons they knew nothing of, would ask for the agent 's opinion as to what should be done, and generally direct him to do what he thought best. The fact is, fow, if any of them, engaged in or took any interest in the practical work of the charity. They considered the Agent who worked among the poor as most capable of advising, and besides getting a suitable agency to relieve want, thought of little else. Naturally the work done was perfunctory, and accomplishod little, if anything. During the first of this year, the comittees ceased to meet, although new material was brought in and every effort made to get them to work. It finally became absolutely certain that our work could not be carried on by District Committees of business men. The work had become confined to a few connected with the central Council. Nothing had been done toward extending the knowledge of the objects and aims of the Society, and among the people at large but little had been done in organizing charities and helping the poor to holp themselves.

"After thoroughly examining the methods of other societies, it was finally determined to adopt the plan of the Associated Charities of Boston. Preparatory to the proposed change, a system of By-Laws providing for District Conferences was adopted, a Directory of Churches and Institutions according to Wards was appended to the Constitution. and By-Laws and published.

"The cases in a Ward were gone over by the Agent, and fresh information obtained. He then visited the pastors of all the churches in the Ward and got the names of the persons in each church engaged in charity work and appointed a meoting for the organization of a Ward Conference to be held 
at one of the churches. In this way, up to October 1 , 1886, there have been organized nine Ward Conferenees. Before winter sets in, all the Wards will be organized. Each Conference has a president, a vice-president for each church in the Ward, and a secretary and treasurer. The Agent reports every new case to the appropriate conference, which takes charge of the case, does what is required, and appoints a Friendly Visitor. By this plan, information of Charity Organization principles goes to charity workers in the churches. Hundreds of workers come in to the work, and the poor are looked after by friends living within easy reach. The work of the Agent is supplemented by the work of hundreds of volunteers, and the organization takes complete possession of the City and its charities--all working together to consider the poor."

The conference meeting place continued to be rotated among the churches in each district. Throughout 1886 and 1887, activities were carefully reported in the press. On May 18, 1886, the Western Conference had held its first anniversary meeting, and Society President, R. H. Blain, reported to the group -- twenty-five ladies -- that the program of each Ward or district looking after its own poor through a Conference was 23

working admirably. It seems evident from similar notices of other meotings that the Conferences were largely, though not entirely, made up of women, and that most of the Friendly Visitors were women, though occasional appeais were made to the men to volunteer for that work. In contrast, no woman was a member of the Central Council throughout the entire history of the society, an interesting indication of the position of women of that day.

23. "The Courier-Journal," May 19, 1886. 
By October 1, 1887, ten District Conferences were meeting regularly. The years 1886,1887 and 1888 were the most active for the District Conference program. Toward the end of 1888, accounts of activities become less evident. By 1890, mention of them ceases, but evidences of evaluation of their failure is lacking, except for the statement by the Central Council: "We greatly regret to say the Ward Conferences have not flourished as they should. This seems to be due to various causes: the loose organization or no organization of church and benevolent societies, the want of understanding of the purpose of the Conferences, and want of individuals in the Ward who will give a little time, take the lead and make a success." ${ }^{24}$ The council believed also that as the city grew, "the poor" were not confined to any particular locality but were scattered throughout the city, which made organization difficult. It is possible that as more confidence was placed in the paid staff the Conference members felt their counsel was less needed. More evident is the concerm, which has been indicated, of the Central Council that the principle of cooperation met so many obstacles and that there continued to be so much duplicated effort in the city. By 1888, the annual report indicates more care was being exercised in the Conference meetings not to give the names of the individual cases where "it could be of no benefit to the case," and this mey have offered less interest and satisfaction to the Conference members.

24. Fifth annual Report of the Charity Organization Society, Louisville, October 1, 1888. 
Although each annual report indicates the Council held to its original premise that Friendly Visitors and Conferences were basic to successful attainment of the objects of the society, the Council was never satisfied with the results. The only indication of the number of persons acting as Friendly Visitors is the Annual Report of 18871888 that there had been 201 Visitors that year, and that this was insufficient, as one Visitor was desired for each family. The constant appeal was for women from better income or wealthy homes, and it seems at least possible that the vivid, sensational case stories appearing in such profusion in the press may have frightened away, rather than interested, these women. The Council frequently expressed regret that other cities were more successful, but offered no explanation as to reasons. Since the cities used for comparison were those in the North and East, it is possible that cultural patterns in theSouthern community as to the position of women may offer some explanation. That the ideas of the Council closely followed those of the general movement throughout the country is indicated by report of three papers given before one session of the National Conference of Charities and Corrections in Omaha in 1887. These papers brought out that there were in the count ry fifty-two cities having Charity Organization Societies. "These cities are making earnost efforts to abolish pauperism by repressive and curative measures, the chief of which is eriendly visitation..... Wise charity is a possible theory and consists in bringing the rich and poor together."

25. "The Courier-Journal," September 1, 1887. 
By 1890, the Council was frank to admit that "all efforts at an organized force of visitors.... has so far proved a signal failure. We have to rely on benerolent individuals wherever they can be found disposed to take charge of individual cases, but are glad to say that so far the supply has been fairly up to demand. Although we cannot, as our principles require, separate the Visitor from the dispenser of alms, time and experience may enable us to do even that." 26 During the later years of the Charity Organization Society, brief mention was made of Friendly Visitors. The Central Council continued to complain that their number was insufficient and that all efforts at organization of the group failed. The Council considered their activity was not sufficiently effective because they could not be "educated" to refrain from giving relief. Care of the Unemployed and Howeless

Almost immediately after formation, the Employment Conmittee sent a printed card to all the leading employers notifying them that the charity Organization Society had "a list of men, honest, sober, and respectable, who are unskilled workmen willing to take either permanent or temporary positions as Porters, Laborers, etc.", and asking for requests to come to the office.

Before the end of the second year, the Central Council began to carry out its philosophy that a "labor test" was essential and "the only way devised by which the line can be drawn and distinction made between the worthy and unworthy." A sub-committee was appointed called "Com-

26. Seventh Annual Report, op. cit. 
mittee of Charity Organization Society on Work for the Needy," to start a Labor Yard and Wayfarers' Rest or Inn. This committee published and circularized a statement of the problem and purpose, and enclosed tickets to be bought and given to applicants to be exchanged for work and pay. In August, 1884, a Reverend Steve Holcomb and Mr. J. T. Burghard established a Wayfarers' Rest in an old station house on First. Streot. During 1886, members of the Central Council visited some other large cities and corresponded with all cities that had similar institutions. As a result, by agreoment with these two men, this institution was consolidated with the Charity Organization Society to be used as a "labor test". The Employment Committee of the Council took over its administration, raised funds for its operation and enlisted the support and patronage of citizens in buying kindling, and hotels and restaurants in giving "broken food. ${ }^{27}$ The Employment Committee continued throughout the history of the society to supervise the institution, to engage and advise the Superintendent, and to make annual reports and solicit support.

The panio of 1893 added some impetus to the acceptance of the idea that some poverty might have its root in economic causes, but did little to move the leaders of the society from their fundamentel ideas of treatment, which remained so closely identified with early English and American Poor Law practice. When Louisville felt the impact of the panic and there was wide spread unemployment, "the Central Council at once took

27. Second Annual Report, op. cit. 
up the question of what should be done to meet the emergency; that relief would have to come from some source, to a larger extent than perhaps ever before, was reasonably certain. Two courses were before us: one, relief without work, the other, relief for work. The one would, undoubtedly, manufacture paupers, the other would preserve and eneourage manhood and work no injury. Relief for work was the decision." ${ }^{28}$ Wood and coal werebought and stored in the yard. Work was given to applicants splitting kindling, building a workshop, etc. Foremen of the rork gave tickets for the work done, which were exchanged by the society for merchant orders.

During this same winter, leading women of the city saw that no such provisions had been made for needy women. The "Woman's Club" took roons in the building, collected a fund, bought material and established a women's work room. Women applicants took the work at the prices fixed. During a short winter period, sixteen hundred garments were cut and made, and one hundred twenty-two women were given employment. The club women themselves bought most of the garments and gave them to the schools, hospitals, and some few to the working woren. 29 It seems significant that once the emergency was over, the society was not able to hold the interest and participation of this very large and influential group of volunteers.

Building on the experience of 1893, the society continued the following year its reliance on work relief, but made an effort early in

28. Eleventh Annual Report of the Charity Organization Society, Louisville, October 1, 1894.

29. Tbid. 
the winter of 1894 to bring the problem of unemployment and the agency's program to the attention of employers. The Executive Committer of the Counoil distributed to omployers a printed statement, made the following suggestions, and in doing so seemed to have some awareness of the inability of private charity to meet the problem single-handed and the need for cooperation of industry.

"1. If it is intended to partially or entirely suspend work during any part of the winter, won't you have your foreman or someone in your employ first ascertain and report to you the number in the family and condition of those you propose to lay off, and if possible retain such as are more dependent, at half time if you can do no better.

"2. If it is intended to lay off say ten men one month, seo if you can reach the same result by working twenty on half time, or, which is practically the same, working one-half the number one week and the other half the next weok, alternating weeks."

President Blain later reported a very favorable response from many manum facturers.

Another evidence of gradual acceptance that all who sought help were not "beggars" was a report of the Wayfarers" Lodge that "the large majority of inmates were not tramps, but unfortunates of a better character." 30 such sentiment continued to be expressed yearly the reafter. About this time, however, a new rule was passed requiring women to work for their care at the Lodge in order to make it less desirable to chronic 31 applicants.

30. "The Courier-Journal," January 23, 1895.

31. "The Commercial," May 21, 1895. 
Evidence that thought was being given to meeting the problem of unemployment and that methods tried elsewhere were felt worthy of consideration locally, was indicated by the prominence given in the local press to reports from other cities of a plan worked out by the New York Charity Organization Society for giving employment to the worthy unemployed men of New York. Three hundred acres of land of a pritate estate were to be used by unemployed men, in quarter of an acre plots for cultivation, the proceeds of the sale of products to belong to the men whose eligibility had been investigated. Reports indicated numerous other cities were experimenting with similar plans. One local paper reported: "There is a disposition on the part of real estate men in some of the cities to protest against the movement on the ground that it will draw attention to the existence of depression and poverty, and tend to keep capital from being invested. The poor are everywhere, and the best way to advance the credit of a community is to better tho condition of these self same poor. The drain upon public and private almsgiving will be lessened by this plan to a greater extent than any of which we know. And it can be developed and expanded beyond the limits of most other aid furnishing schemes." 32

The philosophy of the period and state of developnent of public and private relief locally is well illustrated by a letter sent, with the approval of the Council, on May 5, 1897, to Mary Richmond, who had asked for information to be used in a paper, "The Treatment of the

32. "The Commercial," March 16, 1895. 
Families of Idle and Intemperate Men," for the National Conference of Charities and Corrections. Miss Gellagher, General Secretary, explained that the only state law compelling a man to support his family was "the law that arrests a man for vagrancy and non-support of family, placing a fine and sentence to the workhouse upon him. The dread of this is the only enforcement." Further in the letter, she stated "there is no official outdoor relief in this city." Miss Richmond's question as to the method of treatment of such families by the society brought the answer: "The Charity Organization Society first tests the man by offering him work. Should he refuse to accept this work, he is treated as a vagrant, arrested, fined and sentenced to the workhouse. Then we turn our attention to the family and give them necessary relief. At times wo request that the sentence be suspended so that we may give the man another opportunity to accept work. This proves very effective in bringing a man to a better condition of mind and usefulness."

The program of care of the homeless was not altered by the erection of a new building for the Wayfarers' Lodge. This is described in the annual report of 1893 as follows: We undertake to make the new Lodge more horrible to the tramps than the old one. As soon as admitted to the Lodge, every tramp will be required to bathe, and his clothes will be tho roughly steamed or fumigated. Next to work, the tramp dreads water and cleanliness, and when the latter is added to the first, they will regard our City with holy horror." Annual Meotings

One mothod by which large numbers of lay persons were brought into participation and knowledge of the society was through the annual 
meeting, which was planned by a committee of the council. These me日tings were not occasions to hear authorities, either local or from a distance, but rather for reports by Council officers and members in which they articulated their philosophy about the society and described its activities. Local ministers and musicians participated. The annual report was propared by a committeo of the Council. After the meoting, those in attendance were frequently taken on a tour of inspection of the buildings and the Wayfarers' Lodge and given interpretation of methods of work.

\section{SOCIAL PLANNING}

Development of Community Resources

The Central Council not only appealed continuously for cooperation among existing charitable organizations but also sought to aid in the formation of new community resources. In 1885, it took up the need for a day nursery for "young children of poor women who are compelled to go away from home to work." They were aided in this movement by the interest aroused through "The Evening Times" Fresh Air Fund, and several members of the Council formed an association for the purpose of establishing a Day Nursery and Dispensary. 33 Incorporation as a separate organization was accomplished during 1885; A.G. Munn, vice-president of the society, was elected president of the Day Nursery Board, and the Council actively engaged in the raising of funds for its operation. Apparently in this venture the Council was either ahead of public opinion in seoing the noed for such an institution or else did not make

33. "The Courier-Journal," January 16, 1885. 
sufficient study of the need, for by October 1, 1887, it reported: "The Day Nursery has been discontinued, as that form of charity seemed not to be demanded by the people of this City." 34 Profiting by its earlier experiment, the council did not again take the lead in a movement for a day nursery until there was demonstrated interest by other groups. When several women's organizations, in 1895, showed interest, the Council gave encouragement to them and tangible cooperation by offering the use of several vacant rooms in the building. Cooperation was also given to the free kindergarten movement when two rooms were given to the "Mary $B$. Belknap Kindergarten." 35

In its report of October 1, 1903, the Council took pride in its activities in cooperation with the Citizens' League, Women's Club, and "other uplifting organizations," which had led to the establishment in the city of such agencies and activities as: The Humano Society, Free Bath Houses, Plumbing Inspector, Drinking Fountains, Consumers' League, Kindergarten System, Factory Labor Inspector,School of Domestic Science, Central Howard Association, Louisville Neodlework Guild, Board of Children's Guardians, and The Kentucky Children's Home Society. In 1904, in cooperation with other interested organizations, the Council began efforts toward the establishment of a Juvenile court in the oity. The same year it urged action by the city to empower Health Officers to license and inspect all lodging houses where less than twenty-fire cents a night was charged, to combat the problem of "one-room homes" in the

34. Fourth Annual Report of the Charity Organization Society, Louisville, October 1, 1887.

35. Twelfth Annual Report of the Charity Organization Society, Louisville, October 1, 1895. 
central part of the city, which were in desperate condition. The Council urged that these be abolished and that building laws be arranged to prevent further such construction.

Legislation

The Central Council early showed interest in problems and issues of local, state and national interest. Some of these ventures aroused some question as to the propriety of a private charitable agency engaging in controversial issues. In March, 1886, its action in allying itself with a general movement under the direction of the State Charities Aid Association of New York and endorsing and giving publicity to the need for a Postal Savings Bank of the United States was disapproved by the local press. 36 Such opposition was not expressed to activity of the Council in local and state legislation. As early as March, 1887, President Blain began work on an ordinance providing for fines for railroads, steamboats, and other transportation lines that brought paupers into Louisville, and his contacts with City Councilmen gained their approval of such an ordinance to replace an older one not being enforced. 37

In the fall of 1887, Society President Blain began work on a bill for the protection of children, for the Council was much concerned over the many cases of child beggars and parental neglect of children. $\Delta$ committee of the Central Council actively sponsored President Blain's bill in the Legislature. The Council took much credit that the Legislature of 1888 passed two Acts, to apply only to the City of Louisville, one making

36. "The Courier-Journal," March 16, 1886.

37. "The Courier-Journal, "March 24, 1887. 
vagrancy a misdemeanor, the other authorizing the arrest of infants found begging or in the control of vicious perents, and their committal to an orphanage or appropriate institution. The Council described the results of this legislation as follows: "These Acts have almost put a stop to vagrancy and have enabled the society to reclaim many destitute children."

In 1892, the Council allied itself with others interested in legislation to provide for a House of Reform for Colored Girls, and the need for some provision for "the rescue" of colored children born out of wedlock or abandoned, as there was no provision any where in the state for colored children, except in the House of Refuge in Louisville, which was over-orowded. 39 In 1895, at the invitation of the president of the Lexington Charity Organization Society, the Council supported the effort being made to get a bill before the Legislature for the establishment of a state reformatory for boys and girls; such a bill was passed by the Legislature in 1896. In 1905, the Council allied itself with the movement to restrict pauper and oriminal immigration and gave publicity to a resolution to that effect sent to representatives in Congress. Local and National Participation

The Central Council early was cognizant of the importance of allying itself with the National Conference of Charities and Corrections. On June 23, 1886, it authorized the president to appoint one of the Council as delegates, the president serving as alternate. A subscription

38. Fifth Annual Report, op. cit.

39. Ninth Annual Report of the Charity Organization Society, Louisville, October 1, 1892.

40. "The Louisville Herald," November 29, 1905. 
was taken among the Council members to defray the delegate's expenses. The procedure of discussion of possible delegates by the Council and appointment by the president was followed annually thereafter, but after the first year, there is no mention of a subscription being taken. Delegates reported to the Council, and sometimes to the annual meeting of the society's membership and friends. In 1897 , as many as seven members of the Council were delegates to the National Conference. In 1895, W. T. Rolph, financial secretary, was a delegate, and in an interview upon his return, stated that as a result of his paper before the Conference, the societies of Washington, D. C., and Philadelphia were sending delegations to Louisville to study the Wayfarers' Lodge. In 1897, Mr. Rolph was elected secretary and treasurer of the newly formed Southern Conference of Charities and Corrections, a division of the National Conference, and at the National Conference, he was elected one of the assistant secretaries. At the 1907 Conference, Thos. D. Osborne, a member of the Central Council, was made a member of the Executive Committee. of the National Conference.

That leaders of the society did not confine their activities for social betternent to the society's work is ovident by their leadership in other movements and organizations. The entire extent of such activity is not recorded, but press items reveal some examples. Rudolph Finzer, a member of the central Council, in 1885 was president of the Kentucky Humane Society. When, on June 17, 1886, the Fresh Air Fund was made a permanent organization, Androw Cowan, a Council member, became a member of the executive committee, and several other Council members were on 
41

Fresh Aid Fund sub-committees. Thos. D. Osborne was a mernber of the Board of Trustees of the Kentucky Institution for the BIind. In 1905, members of the Council took an active part in starting the work of the Kentucky Anti-Tuberculosis Association. In 1907, M. S. Barker, of the Council and later president of the associated Charities, was one of a group which incorporated to found the Kentucky Home shelter for the purpose of giving temporary shelter and employment to men and boys who had served prison sentences who came to them properly recomnended.

Throughout the history of the Charity Organization Society, counsel was given to and received from other societies as to methods and programs. Council members visited other cities, carried on correspondence and received representatives of other societies in Louisville. In 1895, the society was visited by the General secretary of the United Charities of Memphis and representatives from the societies in St. Joseph, Missouri and Lexington. In 1904, a committee on public charities conducted by the secretary of the Cincinnati Society and a committe of the Massachusetts Legislature visited the agency and particularly studied the Lodge. Frequent requests were received for reports and copies of By-Laws. .

A change in concept of communty plenning was expressed in the annual meeting of 1900. The major emphasis was a discussion by Miss Mary D. Anderson, of Neighborhood House, and Miss Patty Hill, of the Kindergarten Association, on ways and means of bringing about coopera-

41. "The Evening Times," June 17, 1886.

42. "The Commercial," June 13, 1907. 
tion among the local agencies. As a result of the discussion, President Blain proposed the fomation of a conference in Louisville for mutual information and planning along philanthropic lines, and the first such meoting was held January 3, 1901, with representatives of the Kindergarten Association, Noighborhood House, the Charity Organization Society, the Hebrew Relief society, the Kentucky Children's Home Society, and the Humane Society. The Central Council on February 27, 1901, appointed five of its members to attend the conference for the union of all city charities. 43

A similar movement was developing in the state, and on October 26. 1904, the Central Council voted to aid in the work of establishing a State Conference of Charities and elected delegates to represent the society at a meeting in Lexington to form such an organization. At that meeting. Thos. D. Osborne of the Council was elected the first president of the state conference. 44 The following yoar, the Council strongly adrocated in its annual report the need for a bi-partisan State Board of Charities and Corrections.

At the spring meeting of the Central Council in 1907. Thomas D. Osborne, recording secretary since 1885, moved that the name of the organization be changed to The Associated Charities of Louisvillo, stating that such a change would tend to draw into eloser cooperation the many agencies al ready existing for civic and social betterment. The change as recommended was effected during the summer of 1907.

43. "The Courier-Journal," Fobruary 27, 1901.

44. "The Evening Post," October 26, 1904. 


\section{SLMARY}

Throughout the history of the Charity Organization Society, the Central Council was the dominant and continuous group. District Conferences and Friendly Visitors were active only spasmodically and never fulfilled the roles envisioned by the society's founders. The central Council functioned chiefly through its Executive and standing committers, although many committeos did not function as actively as was originally planned. Membership of these and most spocial comittees was drewn from the Central Council, whose memers were often re-elected for mamy yoars, so that that small select group dominated every activity of the society.

Little other than detail work was delegated to the small paid staff until the latter yoars of the socioty's history. On April 28, 1895 , the ceneral Secretary is first mentioned as attending a meeting of the Central Council, but this did not bocome a regular practice until later. Written reports were sent to the monthly Council meetings by the ceneral Secretary and the Agents. About 1897, the Agents became occasionally to appear at Council meetings to read their reports. In 1903, the General secretary is first mentionod as attending the National Conference of Charities and Corrections, and from about that time on her activities and opinions were more frequently quoted in the press. The paid staff was beginning to have some influence on and importance to the society's work at the close of this period.

In some areas the citizens identified with the agency held firmly to original concepts; in others there is ovidence of slowly forming new 
ideas. There was little lessening of the belief that one of the society's primary objects was the abolition and suppression of begging at almost any cost. Cooperation among charitable agencies and institutions, friendly visiting and investigation were considered basic to meeting the problem of poverty. The Council continued to believe that private charity was the only desirable means of dealing with poverty. There was no acceptance of the need for a public relief program. Their report of 1904 portrayed the "disheartening failure of national state or municipal efforts to abolish pauperism, because they deal generally by wholesale, and the work must be done by retail individually. The more you widen the distance between the giver and the receiver of alms, the greater you make pauperism.......there is hardly a single square in this eity that cannot take care of its own poor." 45 The Couneil held firmly to its purpose of no financial support by public authorities. "The advantage (of the society) to the city is such that the city could well afford to keop up the organization, but that is not desirable, as in that case, our work would necessarily partake of the nature of official relief, and our people would necessarily lose interest in it, except so far as politics could make use of it. ${ }^{46}$

Some modification in the thinking of the society's leaders took place partly because of the failure to win the desired cooperation among charitable societies, institutions and public officials. Little success was attained in securing cooperation of the churches; this may have been

45. Twenty-first Annual Report of the Charity Organization Society, Louisville, October 1, 1904.

46. Seventh Annual Report, op. cit. 
due in part to faulty interpretation, but may also have been the result of the emphasis placed on the separation of the society from organized religion. Another reason for change seems to have been the realization, after a few years of experience, that each winter brought the need for the society to raise funds to meet emergency situations that could not immediately be cared for by some other agency. Failure to win cooperation and delay in meeting needs which brought suffering to the needy was of concern to the society, and by 1888, the Council began to give more expression to the need in the community for a benevolent society whose function would be the dispensing of relief, since the society kept ever before the public that that was not its function.

Economic and political changes gradually brought somo modification in ideas as to the causes of poverty, at least that resulting from unemployment. In the early years omphasis was placed almost entirely on moral causes. Although granting that some poverty might have its roots in economic conditions, the central Council as late as 1892 indicated their philosophy was unchanged as to the meaning of poverty, for they stated: Moverty is sometimes a disease, which, like consumption, is transmitted from generation to generation. It is sometimes an accident. In the one case, it may proceed from vicious, dissolute or lazy habits, in the other from sudden or unavoidable misfortune. In both cases, the same result has been reached--beggary." 47

47. Ninth Annual Report, op. cit. 
From the beginning of the twentioth century to the close of activity under the name of the Charity Organization Society in 1907, there is ovidence of more real change in concepts and activities. Cooperation in aiding in the establishment of new agencies was accelerated. While obviously still considering the Charity Organization Society as the center of almost all welfere activity, the Central Council was more aware of its dependence upon legislation, cooperative social planning, and the development of other resources for the adequate carrying on of its own program. By 1905, there was some change in attitude toward the "labor test," which had been held as a basic principle of determination of need. The Central Council had studied reports of other societies who had abolished the "labor test." Although not yot ready to recommend such abolition here, the Council did recommend that it would be wise to add another Agent to the staff for the purpose of securing work. Commenting further on the Boston and Buffelo plan of employment bureaus, the Council stated: "The ethical value of industrial agencies can hardly be over-estimated .....an employment agency would bring the best results to our efforts." 48 In the same report the Council gave considerable space to the problem of low wages in the city. Government and school reports that fifty per cent of the school age children were out of 8 chool were cited as the basis for stressing the need for truant officers in the sohool system. The previous year, a member of the Council had spoken before a Louisville Ministers' Conference on "Churches Caring for the Poor" and strongly

48. Twenty-8econd annuel Report of the Charity Organization Society, Louisville, October 1, 1905. 
suggested fraternal insurance, mentioning compulsory insurance for laboring classes in Germany and comending some large corporations in America that had adopted similar provisions. By 1906, the Council had instructed the General secretary to attend the meetings of the Child Labor Association.

The change in name from Charity Organization society to Associated Charities at the close of this period was evidence of concrete determination to draw together the many agencies of the city interested in social betterment, to the end that need might not only be alleviated but also prevented.

49. Twentieth Annual Report of the Charity Organization Society, Louisville, October I, 1903. 
CHAPTER III

THE ASSOCIATED CHARITIES OF LOUISVILLE

$$
1907-1922
$$




\section{THE ASSOCIATED CHARITIES OF LOUISVILLE 1 1907-1922}

The years in which the socjety was known as the Associated Charities were ones of marked development in family social work. It was a period devoted to the formation of knowledge and development of techniques for dealing with problems of human relationship. Centers for training for social work, started at the end of the nineteenth century with the organization by the New York Charity Organization Society of the New York School of Social Work in 1898, increased in number and scope. In 1901, the settlement group in Chicago was influential in organizing courses under the Extension Department of the University of Chicago, which later resulted in the present School of Social Service Administration. In 1904, the "School for Social Workers," now Simmons College School of Social Work, was started in Boston. In 1909, the Charity Organization Department of the Russell Sage Foundation was established with Mary Richmond as director. The American Association of Socioties for Organized Charity, the forerunner of the Family Welfare Association of America, was founded in 1911, with Francis Mclean as general secretary, in order to facilitate cooperation betweon agencies with a mutual interest in the improvement of standards and particularly to spread the family social work morement.

1. Material for this chapter, except where otherwise noted, is taken from the Annual Reports of the Associated Charities, minutes of the meetings of the Board of Directors, the Executive Committee, and other standing or special comrittees. Nore documentary evidence of program and procedure is available throughout the Associated 
Discoveries in the field of blology that acquired characteristics are not transmissible gave new impetus to efforts for the control of environment. Under the influence of the social economists, emphasis shifted so far to the side of social responsibility that family social work was all but transformed into a movement for improving social conditions. Great hope was placed in the results that would come from opportunities for all, but experience in working with families brought an awareness of the intricacy of the problem of character building and deopened the conviction of need for oounseling in family problems, personal or environmental. Discoveries in the public health field brought to light new problems that reached into the home and pointed the way to new methods in social work and the need for preventive work. Experiments in food chemistry led to the first skills in budget-making and to counseling in problems of family finance. In the field of psychology, mental measurements were being developed. these experiments in the scientific fields had an influence on family casework and were utilized in its development. The necessity for understanding the nature of the problem in each family before undertaking treatment led to methods of social diagnosis, evolved in part from medical diagnosis and in part from the rules of evidence in the fields of law. This wis the beginning of the application of the scientific method to social casework. Increased opportunities for training and

Charities than was true during the earlier period. Minutes of the Board or Council me日tings are available continuously from 1912 on, Executive Comitteo minutes frorn July 25, 1917, and certain other committees periodically kept detailed minutes of meetings and submitted written reports to the council.

2. Libbey, Betsey, op. cit. 
the growing awareness of need for training to understand and treat the problems of individuals and families brought an increase of workers with at least some training to replace the volunteer visitors of the earlier period. The World War and its aftermath in disrupted lives and in mental and physical illnesses awakened a new interest in the psychology of the individual to which the family field was quick to respond. Toward the latter part of the period of the twenties knowledge from the psychiatric and psychoanalytic fields began to have a great influence on social case work, turning the emphasis from the environment to the personal problems of the individual.

Another characteristic of this period was the movement toward federation of agencies for coordinated fund-raising and financial planning. This led to the formation of community chests and community councils for social planning.

\section{A. ORGANIZATION AND STRUCTURE}

Constitutional Revisions

The organization of the society was little altered by the change of name from Charity Organization Society to Associated Charities in May, 1907. The aims and objects as outlined in the Constitution were unchanged. The new name had been adopted as it was thought that all charitable activities of the community should be contered in one organization. The Articles of Incorporation of the Louisville Charity Organization Society were amended as follows:

"Inow all men by these present, that the Louisville Charity Organization Society, and undersigned, constituting twothirds of its Board of Managers, styled 'Central Committeo,' 
consenting thereto in writing, in pursuance of Section 882 of the Kentucky Statutes, hereby amend Section One (1) of its charter by an Act of the Kentucky Legislature approved on May 9, 1884, Acts 1883-1884, Chapter 1381, page 1052, and surrenders the name and style, 'Louisville Charity Organization Society' and in lieu of said name adopts the following amendment to said Section one (1) to wit:

\#1. The name and style of this organization shall be the 'Associated Charities of Louisville' in lieu of the name 'Louisville Charity Organization Society' in witness the signatures of the corporation and twothirds of its Board of Managers, styled 'Central Committe日, this 7 th day of May, 1907.".

Throughout the history of the Associated Charities, the Council made periodic amendments to the By-Laws on recommendation of a By-Laws Committee. On July 2, 1917, the changes to that time were incorporated into the "By-Laws As Amended to July 2, 1917." These amendments al tered the method through which lay persons participated in the work and influenced the number of those actively identified with the society. Until the organization of the Welfare League in 1917, members of the society were all those contributing to its work. With the beginning of federated financing, all contributors to the Welfare League were considered members of the Associated Charities.

The number of vice-presidents was increased from one to three. Changes were mede in the number and terms of office of the Central Council. 3 The management of the society continued to be vested in the

3. Article III, Section 2, was amended to read: "Twenty-seven members of the Society to be elected at the next annual meeting, October, 1917, seven of whom shall be elected for one year, 
Central Council, known as the Board of Directors, al though the name was not formally changed until a later period. The Board was given control of all questions of principle and all matters relating to the work of the society generally. Responsible to and functioning by authority of the Board were standing and special committees. Chairmen of the standing committees were elected at the first meeting of the Council after the annual meeting. With the exception of the case Committee, 211 comittee members were draw from the Council, a change from the practioe of earlier years.

$$
4
$$

Committees active in the Charity Organization Society and dropped during the history of the Associated Charities were the Membership, the Publicity and Library, and the Cooperation Committeos. New committees were the House or Building Committer, Housing Committee, and Case Committee. The Executive Committer was composed of the president, the first vice-president, and other members of the Council, not exceeding seven, appointed by the prosident, serving as chairman. This committeo was given charge of all the property owmed by the society with full executive and directory power over the business of the society and over the work of the Superintendent and staff, subject to the approval

seven of whom shall be elected for two years, and seven for three years. At each annual meeting thereafter, seven members of the Society shall be elected to the Council for a term of three years. All shall hold office unt il the ir successors have been elected and qualified. The Council may at any time elect not exceeding eight additional members to be known as spocial members from persons whom the Council believes may be especially valuable to the organization.. The term of office of said eight members to expire at the next ennual meeting."

4. Board of Directors Meeting, December 9, 1913. 
5

of the Board. The responsibility of the Finance Committed was unchanged, as was that of the Employment Committee. The Wayferers' Lodge and the Mendicancy Committee were combined. The Legal Committer became the Legal aid Committer. The functions of the new committees were outlined as follows:

1. The House Committeo was charged with reporting at frequent intervals the condition of the hous $\theta$ and property of the society and with the recommending of needed repairs.

2. The Housing Committer was expected to maintain and enlarge the work instituted by the Tenement House Committer. Its principle duty was to assist in the enforcement of the Tenement House Law.

3. The Case Conmitter was to be composed of a chaiman, who was expected to be the superintendent unless the Board desired to elect someone else, and the representatives of such philanthropic, religious and charitable organizations of the city as cared to confer with him concerning cases coming before such organizations where cooperation with or assistance from those organizations was deemed advisable. 6

The Board and Policy Making

The Council or Board of Directors remained the policy-making and consistently active group in the Associated Charities, but functioned largely through its committees which were much more active and better organized than in the earlier period. Another significant change was that by 1910 wornen took their place on several subcommittees and by 1912 were elected to Board mombership.

5. Revision of By-Laws, Article IX., Sec. I., December 27, 1916.

6. Article IX. "standing Comittees and their Duties," By-Laws as Amended to July $2,1917$. 
The Board met in regular session monthly and in special session when need arose. Reports of committees were received and discussed. These reports were at first usually oral, but by 1919 written reports were requested from standing committees. The executive, in this period given the title of superintendent, attended all meetings and reported in detail the work and problems of the agency. Minutes of both the Executive Committee and the Board meetings were recorded by the Superintendent, acting as secretary, and indicate that while the superintendent made various reports, all action was taken by Board members, though it is possible the Superintendent may have minimized his participation in and direction of meotings. There is almost no mention of the planning of meetings of the consultation between Superintendent and individual members which must have played an important part in directing thinking and activity.

Certain tombership of the Board during the early part of the Associated Charities was drawn from executives of other ageneies. This fostered the idea of cooperation, but as the agency became better established and its function began to be more clearly defined, the Board weighed the advisability of continuing this plan, and on December 14. 1920, the Executive Conmitter recommended to the Board that in selecting new members, it would be better to select persons not already connected with other social agencies.

Annually the Board elocted the Superintendent and fixed his salary. When a new Superintendent was engaged, a committeo of the Board acted with the president in making the selection, although in at 
least one instance, the outgoing superintendent carried on much of the correspondence with applicants.

In the early years of the Associated Charities, the Superintendent submitted the names and qualifications of prospective staff members to the Executive Comittee for approval, and the minutes of those meetings indicate qualifications were discussed in detail, and the Superintendent advised as to employment procedure. Similarly any request for loan of any worker for any special task, or the taking on of any special project by a worker or group of workers, was discussed in detail before being authorized by the Board. As early as October 8, 1912, the Board authorized the allowing of time for workers to attend university classes, institutes and conferences; each individual worker's request was considered separately. As much of the time of both the Executive Committer and the entire Board was being taken up with discussion of individual salary increases, the president was authorized by the Board on June 10, 1913, to appoint a Committee on Salaries. The recommendation of this committee, that a salary scale for the entire year be adopted to eliminate discussion, was approved by the Board on December 9, 1913. Subsequently, for a short time, all questions of salaries, changes in duties, leares of absences, etc., were referred to this committee and its recommendations were acted upon by the Board without delay. It is not clear why this procedure soon lapsed, whether the Committee on Salaries preferred not to take this responsibility or whether the Board could not refrain from activity in this area, but within a fow months the plan began to break down and such discussions were again held in Board and Executive 
Committer meetings. Action was often left to the responsibility of the Executive Committee. snother attempt was made to refor such responsibility to a Committeo on Salaries, for on January 12,1915 , a change in the By-Laws was adopted so that Article IX, Section 10, read: "The Salaries Committee shall report to the Council annually at the regular September meeting, or oftener if deemed advisable by the Committee or the Council, the number of employees and their salaries. All questions involving the employment of any persons temporarily or permenently shall be referred to this committee for recommendation." During 1916, this plan was still boing carried out, although some times the Superintendent requested salary increases for staff members at Board meetings. By July 27, 1917, the Board was giving the Superintendont full authority to employ staff and the selection was left to his judgment. This proceduro was incorporated into agency practice by the Board on March 13, 1918, when "the question of filling vacancies was discussed. It was decided that the general policy of the Board would be to leave the filling of racancies in the hands of the Superintendent, but that increases in salaries or radical change inthe policy of staff, or increase in the number, be taken before the Executive Committee for approval."

On April 18, 1919, after considerable discussion, the Board approved one month's vacation with pay for those on the staff six months or longer, and on October 14, 1919, agreed the agency would pay one half the tuition for courses taken at the Jniversity of Louisville. In several instances, leaves of absence for school attendance with 
full pay were voted. But by October 11, 1921, the Executive Committeo recommended that vacations be changed to two reoks with pay and that an additional two weeks might be allowed for any overtime during the year. It was also decided that all absences due to illness were to be discussed with the Executive Committee. Thus, though there was a slight transfer of responsibility regarding personnel practice to the superintendent, the Board still maintained a very active participation in these matters throughout the period of the Associated Charities. During the era of the Charity Organization Society, it was clear the Council was opposed to the acceptance of any public funds, except the delegation to the agency of responsibility for distribution of city coal. With the acceptance of the function of continued relief as a responsibility of the private agency, there was some change in this philosophy and some awareness of the wisdom of using public funds for those services which should later be taken over by the city. As early as March 10, 1914, the Superintendent was instructed by the Board to use appropriations of the City Council for all relief possible, not to include milk, for continued relief clients, and for carfare for children to special schools and clinics. The amount of such contributions by the City is not clear, but the annual report of September 30, 1915, stated: "In the past two or three years, during floods and excessive cold weather, the City has put several thousand dollars at the disposal of this Association for the relief of our poor, and the Chairman of the Board of Safety......has looked into the expenditure of every dollar of the City's money and approved the Associated Charities' plan of investi- 
gation before giving aid." But at the Board meeting on May 13, 1919, a motion was carried that the society should try to avoid accepting any money from City funds "inaswuch as this would create political entanglements", although there is little evidence of events which had transpired in the meantime to account for the change. Again, coal was singled out for separate consideration, for during 1921 the president of the Board attempted without success to persuade the layor to purchase coal for the Associated Charities to distribute.

Speciel committees were frequently appointed to reet with other agencies regarding matters of concern to both. This was one method by which the Board members actively participated in developing policy as to ageney function rather than leaving such matters to the superintendent. Prior to the organization of the Welfare League, the financial organization of the society was flexible, unplanned and indefinite. Special appeals were necessary to meet emergencies or new projects. Although on February 13, 1917, the Board voted to put the finances of the organization on a budget basis, accounts continued to be frequently overdrawn, and the Finance Comittee apparently encountered little difficulty in borrowing necessary funds.' Although with the organization of the League the raising of funds was taken over by the League, the Executive Committee studied in detail the annual budget before it was approved by the Board.

\section{B. FUNCTIONING COMMITTEES}

Case Cormittee

The Case Committee was provided for in the Constitution so that it operated as a part of the agency, yot it might almost be said to have 
been the foremner of the Council of Social Agencies. It was both a lay and professional comittee which met weekly and was open to all organizations and individuals doing philanthropic work. The committeo constantly sought to bring in representatives of other organizations whose cooperation was needed, and each year increased its membership. As an example, the 1912 committee was made up of the following: the supervising nurses at the King's Daughters and the Anti-Tuberculosis Association, the head resident of Wesley House, the president of the Needlework Guild, the chaiman of the relief committee of the ParentTeachers' Association of the Gevin Cochran School, the minister of the Preston Street Mission, the supervising nurse of the Babies'Milk Fund Association, the chief probation officer of the Juvenile Court, the head resident of the Union Gospel Nission, representatives from the Salvation Army, the Broadway School, the Church of the Advent, First Presbyterian Church, the Flower Nission, Fourth Avenue Fresbyterian Church, Warren Momorial Church, and the Church of the Messiah. This comittee seemed able to bring into more active cooperation at loast some of the churches than any other comittee was able to do, although the annual report of the committee to the Council on september 30, 1915, stated: "The churches show small sign of willingness to cooperate."

The meetings of the Case Comittee were given over to discussions of problems arising in families under the care of the Associated Charities or one of the other organizations represented, and by having all of the representatives together, it was found that "a clear understanding of the situation may be reached and the resources of the city 
brought to bear to remove the causes of the trouble." ${ }^{7}$ Duplication of effort was prevented, and "the progress in dealing with the families is much more rapid because it can nove along one line and not be interfered with or changed by new organizations or plans, and because members get acquainted, consultation on other matters is fostered." 8 In 1912, the committeo added a study class; this interest led many of the comittee the following yoar to attend a class in Sociology at the University of Louisville. Committee metings offered an opportunity for the Associated Charities' representatives constantly to outline the society's procedure of investigation and its philosophy of relief giving. Although the consistency of activity of this committee varied from year to year and meetings were reduced to bi-weekly, it continued as a vital part of the organization, growing to a membership of thirty by Jamuary. 1921, and continuing to work "toward a condition of affairs where a family needing guidance and assistance will have but one visitor instead of a stream of different ones." 9

Another function of the Case Committee was direction of the work of the District Conferences. In a meeting of the Board in 1901 with Francis McLean, Field Secretary,Field Department for the Extension of Organized Charity in the United States, he stressed the importance of District Conferences, saying, ".......No society in a city of the size of Louisville can hope to do good work without at least three or four

7. Annual Report of the Associated Charities of Louisville, 1909-1910.

8. Annual Report of the Associated Charities of Louisville, 1912.

9. Annual Report of the Associated Charities of Louisville, 1915. 
good District Conferences serving as locel centers for the work. It is too big a business to be done from one general office....... The Conferences meeting locally and knowing local conditions are bound to materially increase the efficiency of the society in permanently bettering families, and that increase in efficiency is absolutely required if the society is to live as a useful organization. After re-organizing the conferences, the General secretary would be obliged to attend them, constantly watching their growth and keeping them up to their work." 10 In spite of this advice, the society apparently did not make efforts toward reviving the Conferences until 1917. By 1918, four District Committees, three white and one colored, were meeting weokly to discuss and help solve particularly baffling case problems. The committees were made up of social workers, business men, priests and ministers, doctors and school principals. Again the District Conference work died out, although no recorded reasons are given. Re-organization was discussed by the Board in 1919 without results. At the October 12, 1920 Board meeting, it was decided to try to re-organize one white and one colored committeo. It seems significant that in both these instances, the request came from the superintendent who apparently felt the need for lay guidance and that the Board was not so concerned about such participation as were the Board nembers during the early years of the Charity Organization Society. Except for these spasmodic efforts, no real success with District Conferences was attained by the Associated Charitios.

10. Letter from Francis H. McLean, April 26, 1909, sumarizing the discussion of April 19, 1909. 


\section{House Committee}

The House Committee was active consistently and provided work of a nature apparently very satisfying to its members. It supervised the spending of money for repairs of the building, submitted complete estimates to the Board for authorization, and handled details of rental of rooms to other agencies. Many intricate details were attended to in drawing up agreements, purchasing supplies, securing bids, recommending insurance, and many other details of operation. Housing Committer

The Housing Committer, in 1901, made a study of the Tenement House Law recently passed by the Legislature. Prior to passage of the law, there had been in the city a Tenement House Commission, and it had been dissolved with the provision that the Associated Charities would form a Housing Committeo, whose duties should enlarge the work started by the Tenement House Commission and assist in enforcement of the Tenement House Law. The Committee also brought to the attention of the public the housing conditions of families known to the Associated Charities in an effort to keep before the public the need for improved housing.

Legal Aid Committeo

A special committeo of the Board, after several months' study with a comittee from the Society for Legal Aid and Protection, recommended to the Board that this work be made a program of the Associated Charities. After joint agreement by the boards of the two agencies, the Board on October 29, 1913, decided that the Legal Aid Committee 
should be composed of a chairman, who should be a member of the Board, and four additional persons chosen by the chaiman because of fitness for the work. 11 The committee was given responsibility for conferring with the Superintendent regarding all families or persons requiring legal aid or legal advice. By 1914, the committee was empowered by the Board to protect the interests of the poor and those mentally incapable of caring for themselves. Members of the Bar Association sent to the committeo persons requiring legal attention for which they were unable to pay. The committee represented litigants in court when such services were necessary. In the two years, 1913 to 1915, one hundred and thirteon applicants were given service by the comittee. other agencies also referred clients to the committee. In 1917, the committee supervised the issuance of a pamphlet of legal suggestions for soldiers and sailors.

By 1919, there had been a decrease in the work of the Legal Aid Comitter. This was thought to be due to a lack of publicity about the committee and to the fact that the committee was part of the society and that at least some persons were reluctant to come to a charity organization for legal advice. Although during 1920 the committee, then composed of Henry Barker, Grover Sales, and H. E. McElwain, had furnished free legal advice to over seventy-five families, study by the committee of the legal aid provided by other organizations led it to believe its chief service was the stimulation of interest

11. Amendment to Article IX, Section 10, By-Laws. 
on the part of the Jefferson County Bar Association in the formation of a Legal Aid Society. The committeo secured the endorsement of the Board of Trade of the plan, spent several months in work with a committee from the Bar Association, and by Norember, 1920, reported to the Board the Jefferson County Bar Association had authorized the organization of the Legal Aid Society. Mr. Sales was asked to draw up the Constitution and By-Laws for the Legal Aid Society. With the formation of that society, the Legal Aid Comittee ceased activity. Wayfarers' Lodge Committee

The Wayfarers' Lodge Committee continued to supervise operation of the Lodge and advised the Board of policies as to prices of materials to be sold, wages, etc. By 1901, the committee in its annual reports to the Board indicated a reduction in the number of persons cared for. Reasons frequently cited were more prosperous conditions, the disposition of the railroads to carry fowe $\mathrm{r}$ tramps, and the continuation of the "work test." The committeo by 1913 arranged to keep the Lodge open ell night so there would be no need of any stranded person spending the night in a police station. Wit hemployment conditions greatly improved from 1911 through 1913, applications from men decreased and the committee turned its attention to the needs of young applicants, 16 to 20 years of age, and provided more adequate plans for this group.

With the economic depression coincident with the early years of the World War, applications for care at the Lodge increased. Although continuing its interest in the younger men and showing more disposition 
to try to work out plans for those applicants who showed an interest in long time plans, both the comittee and the Board continued to be convinced of the wisdom of the "pay-by-work" lodging house. With the rapid increase in employment opportunities in 1917 and 1918 , there was such a drop in applicants, the Board followed the reconmendation of the committeo and closed the Lodge on April 1, 1918. During the following two years, the comittee continued responsibility for the care of the buildIng and consideration of applications for its rental. Employment Committee

The period in which the Employment Committeo was nost active was al so the War period of 1914-1918. When applications for relief increased in 1914, the Board asked the Employment Committee to increase its membership so that more might be done in searching for employment for men who applied for relief and more of a study of the general employment situation might be made. During the two years, 1916-1918, when the agency assumed partial or entire financial responsibility for the City Employment Bureau, the Employment Committee kept in close touch with its operation and made recommendations to the Board as to needed policies. Advisory Comitteo

The Advisory Committee was in its inception not a part of the organization. The principle of the Charity Organization Society that it was not the agency's function to dispense relief, but rather to investigate need and gain the cooperation of other agencies in giving relief, resulted in increasing dissatisfaction among other agencies and certain community leaders. A group of agency executives and lay per- 
sons, therefore, constituted themselves an Advisory Committee, "to consult with the Superintendent (of the Associated Charities) concerning the families brought to the notice of the Advisory Committer, and to arrange for their care with the combined forces of the various organizations in the city, and to decide questions bearing on the relations of this Society (the Associated Charities) to other social movements in the city. $n^{12}$ The comittee's work was soon accepted by the Board and the committee was made an Advisory Conmittee of the Board. The fact that some of the members of the committee were women led to the acceptance of women as Board members. During most of the year, the committee met weekly, and considerable work was carried on by individual members between meetings. Minutes were carefully kept, monthly reports were made to the Board, and an annual meeting was held to survey the year's work and plan for the future.

In addition to cooperative and legislative activities, the Advisory Comittee exerted considerable influence on the policies of work of the agency. In several instances, it was this Committee that recomrended to the Board the need for additional staff. The Superintendent brought to the comittee discussion of cases involving agency policy; in some instances, the committee called conferences of representatives of other agencies to get needed action. 0ccasionally publicity was sought regarding the needs of a particular family and contributions were received for its use. It was this comitter that

12. Annual Report of the Advisory Committee of the Associated Charities, Louisville, September $30,1910$. 
recomended to the Board that staff members be given time to attend university classes. In 1912 after reviewing the needs of numerous families, the Advisory Comittee presented to the Board an amendment to the By-Laws, which was adopted, that recognized contimed as well as emergency relief as a function of the society. Thus a complete change in philosophy was brought about from the original concept that the society should give no relief, except that given to it designated for a particular family, to the adoption of emergency relief as a neoessity, and finally the recognition that at least some families were in need of continued relief. The committee continued to study such cases and on October 29, 1913, the Board delegated to it responsibility for conferring with the superintendent on all "continued relief cases," so designated, if relief was required for six months or more. The detailed study of these cases brought about an awareness of the need for other resources for such care, and since many such cases were widows with children, the committee began to study and to acquaint the Board with the need for a Mothers' Aid Law.

During the severe flood of early 1913, the Board of Trade decided to handle the relief work through the Associated Charities and all persons who required furniture, olothing or anything other than food or coal, which was provided at relief stations financed by the City, came to the Associated Charities. The Advisory Comitteo was given responsibility for reviewing the facts in every application for house repairs and decided upon the amount to be allowed to each applicant. It also decided on all questions of temporary relief. It is of interest that as a result of its work during the flood, the comittee recomended 
serious consideration be given to the ultimate disposal of "The Point" as a place of residence--a plan finally adopted by the City after the 1937 flood.

Special Committees

In addition to the work of standing cormittees, special committees offered opportunity for laymen to participate in the work of the society. In 1910, the School Children's Thanksgiving Fund Committeo was organized and continued through 1916. This committer, composed of both teachers in the city schools and social workers, met weokly for brief periods for the purpose of devising means of using funds given by the school children for relief purposes.

As a part of the plan to spread the work of raising funds annually to carry on the society's work and to increase the interpretation of the work, a Business Men's or Citizens' Committee of sixty men divided into ten occupational divisions, was organized in 1911 and continued to function each year until the organization of the Welfare League. This organization of men, and later women, into teams for solicitation with daily report luncheons laid the ground work for similar procedure in the League and later the Community Chest. The success of this means of concerted effort to raise funds brought so much larger contributions and so much satisfaction to those participating as to do away largely with the former periodic, rather haphazard, methods of appeal. Several members of the Board served each year as team captains and other captains were drawn from outside the Borrd.

In 1919, the Board organized a Clothing Committes to solicit garments from various church organizations, and a Comittee on Volunteer 
Service to organize the women who were doing friendly visiting. As the work with families were more and more carried on by the paid stafe, less use was made of Friendly Visitors. In the annual report of 1912, however, appreciation was expressed for the work of twenty-five volunte日rs who had given service in visiting applicants and following up investigations. Others loaned automobiles for the use of the paid staff. In addition to these twenty-fire, students from the Baptist and Presbyterian Seminaries, the Nale High School and women from the Second Presbyterian Church and the Unitarian Church assisted in volunteer visiting. Some of these attended meetings of the Case committer, others conferred individually with the Superintendent for direction. During the time the Advisory Committee was responsible for review and authorization of the families receiving continued relief, that committer enlisted volunteer workers so that almost each of these families had a volunteer visitor "not for the purpose of watching them, but to get the very best results by seeing that the moral and physical conditions are as good as they can be." 13 The committer believed families dependent for long periods of time required more attention than the paid staff was able to give. The need for unifying direction of Friendly Visitors working under various committees led to the formation of the Committee on Volunteers in 1919. Annual Meetings

Less responsibility for the drawing up of the annual reports was taken by citizens, as this work was more and more taken over by the 
Superintendent. The individual committees submitted their reports and the president of the Board usually prepared an annual statement, but the Superintendent was responsible for the organization of the whole, although decision as to the form the report should take and the securing of bids for its printing was delegated to a special comittee.

There was a decided decrease in lay attendance at the annual meetings. Dates varied, although a set date was provided by the Constitution, and often the Board allowed a very short time for preparation. The programs of earlier years that offered opportunities for speeches or reports by members of the Board and other community leaders were discontinued. Only occasionally was there an outside speaker. The usual program consisted merely of reports by the superintendent, the president of the Board, and committee chaimen, and the unanimous acceptance of the Nominating Committee's report. It is probably little wonder that attendance dropped to only twenty-five or thirty, scarcely more than the membership of the Board, and that this opportunity for participation and interpretation was largely lost.

\section{c. RELATIONS WITH THE WELFARE LEAGUE AND OTHER AGENCIES}

During this period, many new activities were assumed by the agency until they could be taken over by some other group. The Board and its committees took an active part in developing inter-agency policy. During 1909 and 1910, much of the work of the Advisory Committee was the investigation of complaints about other social agencies. Visits were made, board members of the agency being investigated were interviewed or were asked to appear before the committee. In a fow instances 
of freudulont solicitation of funds, police action was secured to close down the work of the offending agency. As a result of these investigations, the conmittee on April 11, 1910, after studying methods of other cities, recommended the formation of a Charities Endorsement Committeo for the city. The committee asked that the Board suggest to the Board of Trade and the Commercial Club, both of which had made requests for investigations, the advisability of such a committee, and recommended it be composed of three members, one representing the Board of Trade, one the Commercial club, and one the Associated Charities. The plan as adopted by the three groups outlined the duties of the Charities Endorsement Comnittee as follows:

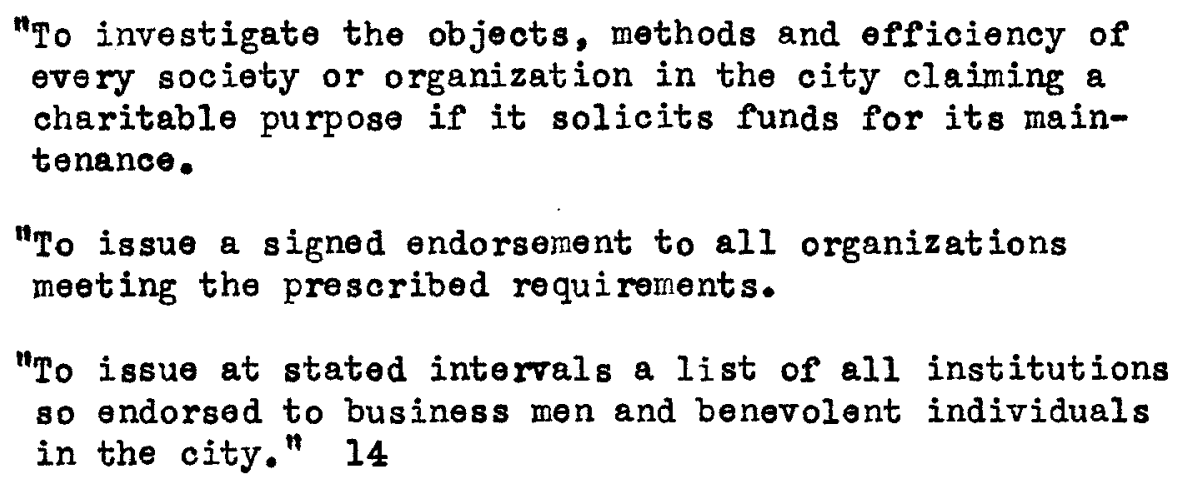
It was hoped by this plan to raise the standards of administration of the philanthropic institutions of the city. The Associated Charities was asked by the Board of Trade and the Commercial Club to perfect the plan and put it into working operation; some years later, the Charities Endorsement Committee was taken over by the Board of Trade. Frequently, the Board acceded to the request of the Charities Endorsement Committee

14. Annual Report of the Advisory Committee, op. cit. 
of the Board of Trade in giving its opinion, after discussion and investigation, as to whother a pending organization should be endorsed by the committer.

The Advisory Comittee in 1909 worked out plans for the better handling of truancy cases between the agency and the Board of Education. During 1911, the committe met with several Parent-Teacher Associations and advised their relief committers as to the administration of their relief funds. This led to several such associations turning over their relief work to the Associated Charities. In 1915 the committeo made a study of the requests made by children at school for car fare. The recomendation of the committee that such requests should be handled with the parents by investigation of Associated Charities workers and that car fare should not be given by the teachers was approved by the Board. On March 12, 1912, a special committeo was appointed to confer with the Children's Hospital and the City Hospital to arrange for surgical operations for colored children. Conferences were held between the Executive Committee and representatives of Waverley Hills Sanitorium during 1919 to work out a policy regarding the fumishing of clothing to patients in the sanitorium. During the same year, several members of the Board accompanied the superintendent in conferring with the County Judge regarding better cooperation between the agency and Juvenile Court. On June 27, 1919, the Executive Committer decided that a fund not to exceed two hundred dollars would be made available for six months for the purpose of guaranteeing the travelling expenses of the officer of the law who might be sent by the court at the request of any social agency in the 
Welfare League in any case of wife, child or family desertion where extradition was desired to bring the deserter to trial.

In 1912 the Board decided to employ a school nurse until the city could take over this responsibility. These and other cooperative health activities were not undertaken merely as palliatives but as part of a deep concern as to the relation between illness and poverty. By 1918 the agency was furnishing workers to make investigations of applications for city coal, for admission to the Home for the Aged, and for the care of beggars removed from the city streets. Requests for investigational service were also made by the Home for the Incurables, the East End Day Nursery, the Union Gospel Mission Day Nursery, the Louisville Flower Mission, the Board of Education, and Waverley Hills Sanitorium; in each instance the Board hoped by giving such service to foster cooperation and to develop gradually the acceptance of good service on the part of these agencies. In 1920, the Board authorized a study in conjunction with the Psychological Clinic of the homes of one hundred children seriously retarded in school and also granted the request of the State Board of Charities for a study of the homes of a number of pauper idiots. After the organization of the Welfare League in 1917, the president of the Board frequently conferred with the president of the League regarding matters of policy. At times a special committee was appointed to confer with the League, but the chairman of the Finance Committer more often represented the agency at the Welfare League. There was a strong urging by the president that every Board momber take an active part in the League's annual campaign for funds, and the Finance Conmitter was 
active in supplying one team of men to work in the campaign. During 1918 and 1919, there was some consultation between the Executive Comittee and the League regarding staff salaries, but the League's recommendation was not considered binding. There was also consultation as to the contribution the agency should make to such organizations as the American Association for Organizing Family Social Work. In all such matters, it was the Board members who carried on the consultation with the League. From the beginning, members of the Board held various positions in the League. In 1921, W. G. Munn, president of the Associated Charities, was second vicepresident of the League; the same year Mrs. R. P. Halleck was on the Budget Committee of the League. Members of the Board served on the general Campaign Comittee of the League.

\section{BUSINESS NANAGENENT AND FINANCE}

The most minute details of agency operation and administration were discussed by and often carried out by the Board or Executive Committeo. These included such matters as insurance, accoptance of gifts, investment of funds, securing of materials for building up-keөp, consideration of bids on work, making of contracts, investigation of the mechanies of the bookkeeping office and devising and setting up the bookkeoping system. The Finance Committeo was responsible for the borrowing of funds, the transfer of funds from one account to another, and the handling of investments. The form which appeals for funds should take was decided by the Board, and the Superintendent was directed when he should seok publicity in the press; at other times, a special committeo of the 
Board would wait on the various papers. The form in which the annual report should be presented was decided by the Board on recommendation of a special committee. Prior to the organization of the Welfare League, the Board decided annually when to have its campaign for funds. After organization of the Welfare League, the Board actively assisted the Superintendent in drawing up the annual budget to be presented to the League.

During the early years of Associated Charities, the Superintendent was appointed annually by the Board as the agency's delegate to the National Conference of Social Work, and his expenses were authorized by the Board. Later it was left to the superintendent's judgment as to who and how many should attend the conference, although the Board decided the amount to be allowed for expenses. The Board apparently was thoroughly convinced of the agency's need to be represented at the National Conference, but in contrast to the earlier period when delegates had always been Board members, this responsibility was now delegated to the professional staff. In March, 1914, the Board decided the agency should be a contributing member of the American Association for Organized Charity, the forerunner of the Family Welfare Association of America. In 1916, it roted to become a contributing member of the Kentucky Conference of Charities, and in 1919, took similar action toward the National Conference of Social Work.

\section{E. SOCIAL PLANNING}

On April 19, 1909, at the meeting with Francis Melean, at which plans were worked out for improving the work of the society, Mr. McLean 
is quoted as saying: "The society is pledged, of course, to carry on social and sanitary reforms in every way to reduce the environmental causes of dependency. It has recently renewed its activites along these lines, and it will be necessary for the General Secretary to bring to the attention of the proper bodies in the society these particular needs." 15 Through the appointment of special committees and through studies, such as that which led to the formation of the Legal Aid Society, the Board actively participated in developing other resources in the community. In December 1912, two members served on a joint committer with the AntiTuberculosis Association to study a Health Codo for the city. As a result of study by another special committee, the Board in 1913 granted the request of the University of Louisville Medical School for a place in the Associated Charities Building for an Out-Patient Obstetrical Clinic. Arrangements were made during 1915 for the bookkeeper to give part time to the Social Service Exchange; room was provided that agency, and the rogistration cards of the Associated Charitios were loaned to the Exchange. Dues of twenty-five dollars annually were paid for membership in the Exchange. After the Exchange was discontinued for a time, the Board, on September 11, 1917, met the roquest of ten other ageneies that the Associated Charities furnish office space and printing to the Exchange for two months, and the Exchange was re-opened. During 1916 one member of the Board consulted with the women's Club regarding recreational facilities for colored children in the public parks. The same year a special

15. Letter from Francis $\mathrm{H}$. McLean, op. cit. 
committer studied school children's relief, and on November 21, 1916, the Board approved the appointment of an additional worker on the staff to take care of this work. Another special committee interested the Mayor in seoking from the railroads reduced transportation rates for the poor. This action resulted in the Mayor writing all the mayors in the state urging investigation before issuing transportation and against the "Passing on" system. On the same date, a committee was appointed to act on the request of the Iien's Federation, a service club, that the Associated Charities join them in petitioning the Nayor and Board of Fublic Safety to establish a Social Service Department at the City Hospital. Early in 1918, the Executive Committer agreed to the request that the society give direction to a worker for the county with the understanding that all relief be borne by the county, since the Constitution limited the work of the society to within the city limits. Early in 1920 at the request of one of the school persons on the Board, a committee was appointed to study the advisability of a scholarship fund to be administered by the school Attendance Department. This committee as appointed by the president had representation from the Associated Charities, the Board of Education, the Kentucky Child Labor Association, and the Welfare League. In 1921, the Board joined with other agencies in the city in asking that a Mental Hygiene Survey, available through the National Comittee for Nental Hygiene, be made and pledged the cooperation of the society. The Board played an important part in the organization of the Welfare League, the forerunner of the Coxmunity Chest. During 1915 , Arthur D. Allen, chairman of the Finance Committee, nade a study of 
federated financing, communicated with other organizations, and recommended the conference method of getting the plan started in Louisville. On February 8, 1916, the Board authorized Mr. Allen to call such a conference, which led to the formation of the Louisville Foderation of Social Agencies, later called the Welfare League, on September 25, 1917. Active participation continued and led to the completion of arrangements, on November 20, 1917, for bringing Elwood Street to be the first director. Members of the Board were also active in the attempts to form a council of social agencies, then spoken of as the Community Council. Several Board members were chairmen of council comittees. Apparently there was much difficulty in winning support for the Council, as in a letter to the Charity Organization Society of Bridgeport, Connecticut, on November 11, 1920, Mr. Wickenden, Superintendent of the Associated Charities, indicated an orror had boen made in organizing the financial federation before a council of social agencies.

As part of its work, the Housing Comittee brought to the attention of the public the lack of Tenement House Inspectors and housing conditions needing immediate correction. One member of the comittee drafted the amendrents to the Tenement House Law passed by the Legislature in 1910. By 1913, the city had employed a Tenement House Inspector with whom the committee was working closely. In 1914, the chairman conveyed to the State Representatives the committee's disapproval of a bill before the Legislature which the committeo believed would repeal the Tenement House Law. The committee in its reports claimed these activities played an important part in the defeat of the bill. Members 
of the committee often made personal investigations of housing conditions in an effort to assist the City Health Department in improving conditions. In 1916, the comittee was authorized by the Board to commicate with the Health Department as to the need for fumigation for tuberculosis. It is of interest that from its work with the Tenement House Inspector and its awareness of the disrepair which soon followed repair when there was poor hous ekeeping, the comittee expressed the hope in its annual report of September 30,1915 , that ultimately the city would appoint "hou sekeepers, or something of the sort, who would go from home to home telling people how to live."

The Wayfarers' Lodge Comittee studied the problem of transiency and migration and significantly through this study gradually came to express a philosophy differing radically from the earlier one of "passing on" or repressing of wandering. By 1914, the committee expressed to the Board the need for more cooperation between municipalities in dealing with the problem of the casual laborer or the idle man. Communication was carried on with nearby cities in an effort to work out plans for the prevention of aimless wandering.

The Advisory Committee not only carried out its stated purpose of cooperative efforts with other agencies but also studied and sponsored legislation. It worked with the Comercial club in requesting the State Legislature to appoint a commission to inspect state institutions. When the Babies Milk Fund Association foundbad conditions in homes where babies were being boarded, it carried on an investigation of "baby fams" with a view toward recommending city legislation. The 
comittee summarized the investigation, made by the staff, of the health of school children and drafted the letter which the Board approved and sent to the Board of Education recommending the introduction of school nurses into the schools of the city. Also in the health field, the committer, on the basis of information supplied by the agency stafe, recommended to the Board that school authorities and the district nurses of the King's Daughters be asked to unite with the Associated Charities in requesting the City Health Department to present an ordinance to the City Council asking for quarantine of cases of measles, whooping cough, chicken pox, and other contagious diseases not already covered by existing ordinances. This plan was carried out, and the city Health officer made such recomendations in his report to the City Council, but the Council failed to act. In 1911, the comittee studied not only the local problems of truancy, but also secured data from other cities and outlined a plan for the suppression of truancy in the city, which was accepted by the Superintendent of Schools.

In 1912, Stuart Chevalier, a member of the committee, prepared an Anti-Loan Shark Bill which was passed by the Legislature. The problem of wife-desertion was also studied by the committee; one member served on a comittee representing several social agencies which drafted a bill bearing on the subject, which failed to pass the Legislature. In 1914, the committee cooperated with the Board of Fublic Safety in carrying out the decision to discourage the street vending of shoe strings and lead pencils by actively attempting to find employment for handicapped persons so engaged or recomending that the Associated Charities give relief until such employment could be found. 
The Employment Committee and the Boare were active in efforts to secure public employment services. Members of the Employment Committeo joined with representatives of the Board of Trade and Conmereial Club in 1914 in asking the Mayor to use unemployed men in work on the city streets. Periodically when there was a danger of the City Employment Bureau being shut down, the Employment Cormitteo was active in working for its continuance and expressing the conviction that such help was necossary to meet the mounting unemployment problems. In the winter of 1914-1915, the Mayor's Committee on Unemployment was formed, and the Nayor responded to the request of the Associated Charities' committee and other organizations that unemployment could be met in part by use of the unemployed on street work. When city officials announced the inability of the city to continue the Employment Bureau, the Board agreed that the Associated Charities would take over the entire expense for eight months to October 1916. The Mayor's Unemployment Committee was to remein in direct charge and the Bureau was to continue to be located in the City Hall. During this time, however, the Board and the Employment Committee continued to urge that the Employment Bureau was the responsibility of the city. In October, 1916, when the city was still unable to take over the Bureau, the Board decided to continue its responsibility for another six months (the Bureau was not finally discontinued until 1918), but to print the report of the Employment Bureau separately from the annual report of the agency in order to call attention to the city's responsibility. All of this study of the unemployment problem by the Board and Employment Committee brought about a change in attitude toward the problem in striking con- 
trast to the earlier moralistic attitude toward unemployment. Thus the Board of Directors in its annual report of September 30, 1916, spoke of "unemployment as a disease, not confined to periods of business and industrial depression when it assumes epidemic proportions, but (it) is always with us....there are cyclical fluctuations..... and seasonal fluctuations affecting practically every industry.....changes in management often cause workers to be thrown on the market....the closing of a factory or store adds to the supply of job seekers."

Fred Drexler, a member of the Board, served during much of this period as chairman of the Sub-committee on the Employment Buroau of the Mayor's Compittee on Unemployment, and his work and that of the society's Employment Committee laid much of the ground work for the Federal Employment Bureau established in Louisville in 1918.

\section{F. CHANGE OF NAME}

By 1919, there had grown a demand on the part of the professional workers for a change of name of the agency. With the organization of the Welfare League, it was thought that the name was no longer appropriate, and there was a growing conviction on the part of the workers that the emphesis should be placed on "service" rather than "charity." The Board acceded to the request and appointed a Committee on Change of Name which studied the question for almost two years. Correspondence was carried on with other agencies, many of whom we going through similar explorations and with the American Association for Organizing Family Social Work; questionneires were sent out, and by December, 1921, the committee recomended the choice of Family Service Organization as the 
now name for the society. The change was adopted by the Board and announced to the public through the press on December 14, 1921. Thus a change in emphasis was brought about which had been growing slowly throughout the history of the Associated Charities. As early as October, 1914, in making the annual report, President M. S. Barker forecast this change as he stated: "The Associated Charities (formerly) used practically all its funds for investigation, as did most of the organized charity societies of the United States. The belief existed that there was plenty of relief dispensed, but that most of it went wrong. The fallacy of this belief has been proven. Relief work was inadequately done, families were broken up that could have been saved, most people died of tuberculosis and kindred diseases because they were poorly fed and hou sed. It is the effort of the Associated Charities at present all over the country to preserve the family and the best influence of the home." This change brought about an interest on the part of the Board in the Mothers' Pension movement, in Workmen's Compensation, health insurance, and in all of the aids which the home economics field could bring to better family Iiving.

\section{STMARY}

As in the earlier period, the Board continued as the organization which directed and correlated lay activity, but in this period functioned largely through its committees. Although the use of both District Conferences and volunteer visiting decreased, and many of the earlier values of the annual meetings were 10st, the increase of other committees maintained the active identification of many citizens with the agency. 
The organization of the Welfare League called for a new type of cooperating activity but resulted in the loss of identification of contributors with a particular agency. The agency took on many new activities until these could be gradually assumed by other agencies, and the Board apparently was eager to grant the request of alrost any group for service. The emphasis on cooperative social planning aided in the development of other social services and laid the ground work for the formation of the Council of Social Agencies.

Changes in philosophy were evident in several areas. Not only emergency but also continued relief was accepted as the function of the agency. Public subsidy was accepted where previously it had been abhored. Citizens identified with the agency were loath to admit the private agency could not meet any problem, but gradually accepted its inability to cope with large scele unemployment. Although the pay-by-work lodging house was still considered the best method of care for the homeless, there was a gradual acceptance of the need for more long-time treatrent. Although Constitutional objects and principles were unchanged, much less attention was given to the suppression of begging and need was no longer related in all instances to moral causes. Relief was no longer considered the cure alone for need, but service was accepted as necessary to treatment of social and personal problems.

During the history of the Associated Charities, the professional worker began to share or to take over various responsibilities formerly assumed by the layman. The increasing confidence in the paid staff and drawing away by the Board from participation in the case work of the 
agency was in marked contrast to the early days of participation in and direction of every phase of work and seoms to indicate a growing acceptance of the professional nature of case work. The actual interpretation of the work of the society gradually came to be the responsibility of the Superintendent. Some personnel responsibilities were likewise delegated to him. The Board withdrew completely during this period from participation in the National Conference of Social Work. This delegation of some responsibilities to the professional staff did not lessen the Board's participation in social planning and roform, and many such programs were originated or assisted by the Board in this period. By the end of this period, there was quite general acceptance by those laymen most closely associated with the society of the necessity for professional training for the staff. The employment of a Home Econonist on the staff and awareness of the complexity of family problems brought a conviction that training was needed if adequate diagnosis and treatment was to rosult. 
CHAPTER IV

THE FAMILY SERVICE ORGANIZATION OF LOUISVILLE

$1922-1929$ 
THE FAMILY SERVICE ORGANIZATION

1922-1929

The development of family social work naturally does not fall into the exact periods into which the history of the Family Service Organization has been divided. It is possible, however, to describe generally certain characteristics of the periods approximating these divisions. The period of the 1920's was one characterized by federation, correlation, social planning and efforts toward standardization. National organizations such as the American Association of Social Workers, the Americen Association for Organizing Family Social Work which, in this period, became the Family Welfare Association of America, and public welfare organizations all played an important part in these trends. The community chest and councils movenent, which began in the preceding period, contributed to communities by improving the work of individual social agencies, stimulating cooperation, demonstrating needs and developing a better community program. Community chests not only continued their original function of federated fund raising but also worked toward standardization of financial methods and toward better community understanding of social work through education, publicity and surveys.

1. Material for this chapter, except where otherwise indicated, is taken from records of the meetings of the Board of Directors and standing and special committees, annual reports, correspondence, reports of the Welfare League and Conmunity Chest, monthly reports of the Ceneral Secretary and District Supervisors, records of the District Conmittees, and newrspaper clippings. 
In the private field, there was an increased emphasis on prevention. In social work generally, and in partioular in the private family field, there was a greater emphas is than ever before on the need for education in scientific mothods of dealing with the difficult problems of human relationship. The body of lnowledge for training was constantly increased by research and the infiltration of naw knowledge from other fields. Correlated with this was an increased conviction of the possibility through case work of ass isting in the edjustment of human relationships. This conviction was expressed in a statement by Philip Klein, Executive Secretary of the American Association of Social Workers: "The social workers have discovered a now method, applicable in large numbers and much more efficacious than that of handing out material relief, namely, case work or personal adjustment. This method hes been found excellent, not only in supplementing material relief, but also in many cases in supplanting it. The case work technique has been the greatest discovery in the tool chest of the social worker concerned with the group that is submerged because of social and industrial conditions, and because, froquently, of biological conditions..... Case workers, therefore, see a large and attractive field of plying this newly discovered tool, namely, the case work method, in an extensive field concerned with the personal relations of individuels wherever found in the social scheme." The refinement of the cese work method brought with it conviction of the need for more adequate relief in contrast to the subsistence 
standard of the past, and more awareness of the effects of relief on the recipient. The possibilities of case work also brought a concern over high case loads and attention to definition of function in contrast to the eagerness to take services in the earlier periods. Where both private and public agencies existed in a community, there were beginning efforts to define division of responsibility. The private organization generally took responsibility for developing new resources for groups the family agencies believed should no longer be their responsibility.

Some gains had been made in the public field in the preceding decade, notably the passage of the first Mothers' Aid Lew in 1911. But the World War with its rapid and wide expansion of Home Service by the American Red Cross, threw the weight of professional interest again into the private fields. This trend was intensified by the attention given to the council and community chest movement, so that by the end of the $20^{\prime}$ s the majority of urban social workers in private agencies gave more attention to their own field than to the welfare activities of government. Under the leadership of the United States Children's Bureau, however, many state departments made progress in programs of child care and protection, and by 1931 forty-five states had enacted Mothers' Aid logislation. "The federal and state agencies had little or no official relationship with locel public outdoor relief, and, therefore, little contact with city public welfare departments. The task of 'socializing' these local departments, therefore, was assumed by the private family welfare societies. In 1918, the American Association for Organizing 
Family Social Work passed resolutions urging its member societies to take advantage of opportunities to socialize public charities, and to agreo upon a division of work with socialized departments based on types of family problems rather than upon differences of function. In spite of these improvements, however, the family welfare leaders continued to be skeptical of both the soundness and practicability of public aid and this conservative position continued well into the unemployment emergency of the $30^{\prime} \mathrm{s} . "$ By the late $20^{\prime} \mathrm{s}$ there were scattered "socialized departments" in a fow cities and rural counties but these public ventures were in the minority. "The social work world was still dominated by private agency attitudes, philosophy and methods which so influenced public opinion that when the depression came, community after community logically looked to the private agencies to meet the overwhelmingly increased demands for relief. Community chests and financjal social federations, which had developed in most large cities...bore the brunt of this community expectancy. The wide dissemination through the years of argunents in favor of private charity and against public relief had conditioned public opinion to a far greater extent than was realized even by many of the family welfare leaders themselves... This accounts for the wave of unbelief that greeted figures of the Bureau of Social Statistics that in $1928,71.6$ percent of all relief in fifteen important cities was. from public funds. This statisticel evidence immediately and finally took the whole question of public versus private responsibility for relief out of the realm of conflict theory into that of hard fact." 3

3. Brown, Josephine, Public Relief 1929-1939, pages 3 to 59, New York, Henry Holt and Company, 1940. 
Locelly there were several outstanding developments. Permissive Mothers' Aid legislation was enacted in Kentucky in 1928 and accepted in Jefferson County the same year. In 1924 permissive Blind Pensions and in 1926 permissive Old Age Pension legislation was enacted. The post war depression and diminished index of employment in industry resulted in increasing applications for relief. This trend, relieved by occasional short lulls, continued throughout the period increasing toward its end. In spite of these definite evidences of the permanency of the unemployment problem even before 1929, unemployment continued to be looked upon as an emergency. The growth of the city and the inclusion of outlying territory into the city limits was another factor in the increased need for relief within the city. The period was one of slow but inoreasingly rocal insistence on public authorities taking their share of the responsibility and the beginning of specific public appropriations for relief. There was a decided increase in the problem of transiency. Restlessness due to unemployment was an important cause generally, but locally the problem was in part the result of large numbers of men quartered near the city during the World War who returned seoking employment or ties formed during that period. The industrialization of industry and the movement from rural to urban centers and from the doep South to the North both played an important part in the transient problem. In 1926 a state wide Transient Committeo was formed which aided in building up a list of correspondents through the state. In 1927, in Louisville, a survey and experiment in centralization of service to transients led, in 1929 , to permanent centralization of the 
care of transients, who had been in the city less than two woeks, with the Travelers Aid Society.

The Family Service Organization and other member agencies of the Welfare League united to form the Community Chest in 1923, which was an extension of the idea of cooperation in community-wide welfare work. Although the Community Chest assumed responsibility for the raising of funds, the member agencies retained individual rights of policy and administration in individual boards of directors. The Community Council was reorganized into the Health, the Family and Child Welfare and Recreation Counoils of the Chest.

The reason for the change of name from Associated Charities to Family Service Organization was better to describe the function of service to the family as a whole, whether relief was needed or not, and to help the community understand better that only a part of the society's work was relief giving. The change also suggested the change in case work toward emphasis on service rather than reform, and family adjustment toward greater efficiency and happiness.

Although case loads increased during this period, there was at the same time an avowed purpose of giving trained service to families who were unable to maintain normal life. The importance of getting at the underlying causes of problems was the principle constantly held before the visitors. Relief was seen only as a part of service and as a service in itself. There was much attention to giving the public some understanding of the function of the society. Coincident with these changes was the change in philosophy toward more adequate relief. 
Although budget restrictions often made it necessary to give most inadequately, there was the constantly interpreted conviction of the need for and wisdom of adequate relief and at the same time a decrying of the fact that the agency had become "the relief pocket book of the community." The period was one of great turn-over in staff. There was much greater emphasis on training. The Louisville School of Social Work was organized in 1922, and many of the workers took courses; some, with small salaries, were helped with tuition fees by the society. By 1926 , when the School of Social Work had ceased operation, the society developed its own training program. Although as case loads increased there was an increase in staff and in budget, all did not progress tógether, and much of the activity of both lay and professional groups centered around attempts to get more adequate relief and more adequate staff so that case loads might be lowered.

\section{A. ORGANIZATION AND STRUCTURE}

The change of name from Associated Charities to Family Service Organization in order better to describe the function of the agency and to distinguish clearly between it and the Welfare League did not alter the structure or organization.

Constitutional revisions wore not made until 1928 after study by a committer to revise the Constitution and By-Laws. During most of this

4. Report of the ceneral Secretary, 1926.

5. Among the changes adopted by the Board was the amending of Article I to change the name of the Society to the "Family Service Organization of Louisville and Jefferson County, Kentucky" and the striking out of the phrase "and its work shall be confined to that city." The words "Central Council" were changed to "Board of Directors." In the By-Laws, membership in the organization was changed to "all 
period, there was little attention to Constitutional provisions in the formation of committees, but the 1928 revision again provided for specific comittee organization.

Leadership of the Board and its committees declined during the first two years of the Family Service Organization when the agency was without an executive. Linton Swift, general secretery in 1924, was aware of the need for reorganizing and stimulating lay activity. This conviction he outlined to the Board:

"The development of the Family Service Organization has now reached a stage which requires the active cooperation of the Board of Directors, through its committees, if we are to maintain our proper standing and influence in the community. Our work has revealed many great community problems with which the staff alone cannot cope.....upon the Board rests the responsibility and the function of seeing that the work as a whole meets the needs of the community; of forming general policies; of securing necessary legislation; and of bringing such influence to bear upon the courts, city authorities and institutions as to make them of greater service to the thousands whom we are helping..... Such work cannot be done effectively by the Board as a whole, merely through attendance at monthly meetings. It requires the steady formulation and carrying out of plans by committees responsible to the Board. Above all, it requires personal influence and cooperation with other agencies and city authorities, and the awakening of public interest." 7

persons paying five $(\$ 5.00)$ dollars or more annually to the Com-

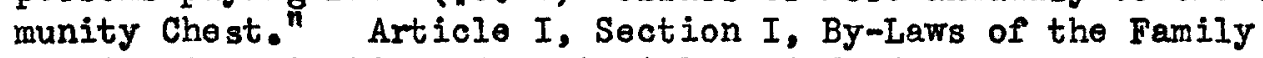
Service Organization of Louisville and Jefferson County.

6. By-Laws, Article V, Sections I and II: "The standing committees of the organization shall be an executive, a finance committer, a case policy committer, a house committee, a volunteer committer, and a publicity committee."

7. Statement of the General Secretary to the Board, September,1924. 
In September 1924, the president and the General Secretary outlined in detail plans for the following committees: Executire, Policy, District Conference, Volunteer, Building, Cooperation, Employment, Housing, and Publicity. Some of these were not created immediately, others seem never to have been started, and the ceneral Secretary occasionally conmented on the lack of activity of those created. The Legal Aid and Wayfarers' Lodge Comnitteos, so active in the previous period, functioned littlo and were not included in the re-organization plans. Financial advice, so often given by the Finance Committeo during earlier periods of the society. was largely centered in the treasurer or other individual Board members after rosponsibility for fund raising was assumed by the Community Chest. In March 1922, this committeo was authorized to take care of the extension of bonds in which agency funds were invested. One meoting of the Finance Committee in 1928 is the only other mention of the committeo. The treasurer was responsible for recomending investments for bequests to the agency and carrying out the decisions of the Board, and for suggesting changes in the bookkeoping department.

The Publicity Committee was particularly active at the time of the annual meetings. It advised the General Secretary and a staff publicity comittee over a period of several years in developing sound publicity and interpretation plans, and was helpful in securing radio and pross publicity.

For a time, both a House and a Building Committes existed but the functions of building, remodeling and supervision of buildings and grounds were later combined in the Building Committee. 
The Board and the Executive Committee

The central authority of the organization was vested in the Board of Directors. Preceding the annual meeting the prosident appointed a Nominating Committee both to propose now members and to draw up a slate of officers. Sometimes during the year, the Nominating Committee suggested persons to fill Board racancies; at other times vacancies wore filled by nomination of any member of the Board, often by discussion first in Executive Committeo. Qualifications for Board members were not set forth; sometimes the emphasis was on the individual; sometimes on the group the individual represented, as illustrated by suoh recommendations as "a good labor man be secured to fill, if possible, the next vacancy on the Board," the noed for a "Catholic layman" and "someone from the Board of Education." In 1929 in considering now members, the Nominating Committee worked from a classification of the Board at that time as follows: businessmen 12; women 8; ministers and priests 3; lawyers 2; nowspaper mon 1; architect 1. Groups from which it was felt advisable to draw were: physicians, labor, university, advertising, schools, and Catholic laymen.

The Boord continued at first to meet monthly, except during the sumer, and elected its officers and committee chaimen at the meeting following the election of the Board at the annual meeting. Some committeos made monthly reports to the Board. On April 12, 1923, at the suggestion of the General Secretary, the Board voted to hold its regular meotings quarterly instead of monthly, save on special call, but recommended the Executive Cormitter should meet at least monthly, and that 
other standing committers should meet at least monthly except during the summer. This change was made with the announced purpose of allowing more time for committee work. On at least one occasion, Board members questioned having only quarterly meetings which centralized much authority in the General Secretary and the seven members of the Executive Committee. The plan of having the Executive Committee meet "at least monthly" was not carried out. On the basis of these facts, one is inclined to wonder whether the outline of lay activities made by the General Secretary and president in 1924 was somewhat theoretical or whether the General Secretary visualized many opportunities for participation which he was either unable to stimulate or which were beyond the current interests of the citizens identified with the society. The decision to lessen the frequency of the Board meotings raises the question whether it was motivated by a desire to stimulate more activity through committeo work or whether it was a conscious or unconscious evidence of the philosophy of the professional staff as to the necessity for or adequacy of Board activity. Another important influence seems to have been the desire of the president to centralize authority in himself and the Generel Secretary. In June 1925, the Board's decision to return to monthly meetings and more frequent meetings of the Executive Comittee seems to have indicated a definite desire for more activity. This desire was not met by the General Secretary immediately, and for some time meetings of both the Board and Executive Committee were often several months apart. In the face of recurring emergencies, Board meetings increased until by 1928 the Board was having ten meetings a year. 
The trend, indicated in the last period, of increased activity on the part of the Superintendent--referred to in this period as General Secretary by reason of amendnent of the By-Laws on April 11, 1922--was noticeably increased. A much larger portion of Board minutes was devoted to interprotation to the Board by the General Secretary. This may be in part due to methods of recording, but also seems related to the necessity for interpretation of changing function, the meaning of case work service, workers' capacities, etc. Much attention was also given to comparison of local resources with those of other commities. In meny meetings, according to the minutes, every iter: of business was brought up by the General Secretary, the Board functioning largely at those times in approving, enlarging, or slightly altering plans already drawn in detail by the General Secretary. Although the professional staff had come to take responsibility for the case work, and the ceneral secretary responsibility for administration, there is indication of much, sometimes daily, conferring between the ceneral secretary and the president of the Board, almost none of which was recorded. From 1922 through 1926, case material was frequently presented at Board meetings, not for authorization as in former years, but for interpretative purposes. The supervisory staff often attended Board meetings and case material was frequently presented by them rather than the cenerel secretary.

The annuel budget was discussed and approved by the Board before presentation to the Community Chest. The Boerd regularly authorized any changes in the financial set up, organization or operation of the agency. Another regular function of the Board was the annual authori- 
zation of the signing of the Transportation Agreement of Allied Social Agencies, until this responsibility was delegated to the General Secretary in later years. In October, 1922, the Board gave definite assistance in drawing up legal arrangements for establishing more systematic control over expenditures and authorized changes in the bookkeeping system. Bids for purchases of such items as fuel were secured and approved by the Board until 1927 when it was decided to leave such matters to the president and General Seoretary. In 1926 and 1928, the Board authorized study of the entire insurance progrem of the society by two members and approved their recomendations. Annually there was a discussion of the purchase of automobiles, although the final authority was delegated to one remer of the Board acting with the General Secretery. The Board as a whole took less responsibility for personnel matters than in earlier years. The General secretary presented staff resignations as a formality. On Narch 4, 1927, the Board ruled the Generel secretary had authority to increase the staff if, in his opinion, an emergency warranted such action. The Boerd, however, euthorized salary increases of the Case Supervisor.

During this period, the Executive Comittee was a more active group than the Board as a whole. Except where it was authorized to act in a certain matter, the Executive Committee, however, did not act independently; the usual procedure was for the committee to report to the Bos.rd, often after several beetings, any real decisions, and to secure the Board's approval. It served as a smeller group that could weigh problems before their presentation to the Board, thus giving leadership, 
preparing the ground work and ruling out non-essentials. The wording of resolutions was frequently worked out in Executive Comittee. The Board did not blindly follow the recormendations of the comittee but their deliberations did prove a time saver for the entire Board. As was true of the Board, the Executive Committee, too, was inclined to give the General secretary much more power to act in many matters than had been true in former years and more and more depended on his leadership to initiate the material to be acted upon.

The annual budget was discussed by the Executive Committeo prior to its presentation to the Board. Changes were frequently made in the original budget prepared by the General secretary, but it was his responsibility to make up the proposed budget in contrast to earlier years when much of this responsibility was shared by a group of Board members. Alterations recommended by the Building Comittee we re considered, but execution of plans was left to the Building Compittee and the ceneral Secretary.

The Executive Committee was active in personnel policies. In 1922 and 1924, the Executive Committee, after discussing with the entire Board various possibilities for a new General secretary and the salary to be offered, was empowe red to make the final selection. Later the same year, the ceneral Secretary waited on the approval of the Executive Committee before dismissing the Case Supervisor. The General secretary secured the approval of the comittee for employment of workers, salaries, authorization for workers' use of their own cars at agency expense, promotions, sick leave, re-arrangements of districts, shifting of personnel, 
and loan of staff. In December 1922, the Executive Committer approved the granting of one month's vacation for all workers on the staff one year. Variations in vacation and sick leave policy were, however, left to the General Secretary's discretion. Where considerable increase in staff was needed, it was necessary to request additional funds from the Welfare League, and by mid-1922 there was a noticeable tendency to authorize the General Secretary to take up such matters with the League and commications began more and more to be between the two executives. In 1926, the Executive Committee, on the request of the Ceneral Secretary, discussed the salary scale for senior visitors and authorized the remoral of the upper limit so that more might be paid on the recommendation of the General Secretary and the approval of the Executive Comittee. By action of the Board on Narch 2, 1926, the equalization of salaries was left to the discretion of the Executive Committee and the General Secretary. In September, 1928, on the basis of these periodic discussions of salaries in either Board or Executive Comittee meetings, the Cenerel Secretary was asked to make a study of salary schedules in other family agencies of a comparable size.

The Board continued to authorize the expenses of one or nore staff members to attend the National Conference of Social Work, but did not take responsibility for representing the society themselves. As the service to the society of the American Association for Organizing Family Social Work, later, the Family Welfare Association of America, bocame more tangible, Board members were active in accepting, even urging, the increase of the budget item for dues to the national organization. In 1925, Mrs. 
R. P. Halleck was elected to the executive comittee of the national organization, and in 1927 attended the Fiftieth Anniversary meeting and later was appointed a member of the Regional Committee for the South. After re-organization into the Family Welfare Association of America, the Board decided to continue membership in the national organization.

B. RELATIONS WITH THE CONUNITY CHEST AIND OTHER AGENCIES ${ }^{8}$

As has been indicated in the general outline of developments of this period, the outstanding concerns of the agency were the increasing demands upon its services which, in turn, stimulated awareness of the need for developing other resources and for defining the function of the private agency. The increasing case loads and need for more relief did not submerge all other activities but certainly the thinking and activities of the Board and its committeos were more largely focused upon or were affected by efforts to secure increased funds, and, therefore, with the relationship to the Conmunity Chest, the development of public relief and the defining of the society's relationship to other resources in the community.

The giving over of responsibility to the Community Chest for fundraising and determination of budget was not easy for a group who, for 80 many years, until the formation of the Welfare League, had been independend in these matters. Had the Community Chest functioned for a longer period before the sudden increase in relief demands, it seem possible

8. A full picture of agency-Chest relationships would call for an historical study of the Commity chest, its program and problems, not possible within the limits of this study. 
some of the areas of conflict might have been averted. But several years of unsuccessful campaigns and miscalculation of budget, through inexperience or lack of awareness of needs, only added at times to misunderstandings. One could almost say that there was an intellectual acceptance of the soundness of the chest plan without emotional acceptance of its validity in poriods of stress. The principle enunciated by both the Chest and agency that the right to decide how decreases in budget should be allotted remained the right of the individual agencies within the Chest influenced action of the Board regarding decreases. The Board was naturally jealous of its rights and was closer to the needs of the agency than were those citizens identified solely with the Commuity Chest and of necessity concerned with the needs of all chest agencies. It seams possible also that the Chest board represented more often power and wealth in the community than did the agency Board and that the social philosophy of the two groups may have differed. Members of the Board, in 1922 and 1923 as many as twelve, were active during the annual campaign for funds. Their interest differed, however, from that when theirs was the sole responsibility for raising funds for the agency, and it was the frequently expressed opinion of Linton Swift, General Secretary, that for the Board as a whole, there was a definitely lessened feeling of responsibility for raising of funds after the organization of the League.

Throughout this period, individual active or past Board members filled various positions of responsibility in the Community Chest. Among these were Arthur D. Allen, who, as chaiman of the Finance Comitteo, had been active in organizing the. Welfare League and was president of the 
Community Chest in 1926 and 1927. For several years, Mrs. R.P. Halleck was chaiman of the Family and Child Welfare Council of the Chest, Mrs. George T. Wood, who was later to become executive of the Council of Social Agencies, was, while a member of the Board, chairman of the Investigation Committee of the Community Christmas Comittee. Mrs. Charles Semple was on both the Health Council and the Social Planning Council of the Chest; Mrs. J. E. Riddell was chaiman of the Comitteo on Day Nurseries, and Mrs. Louis Seelbach chairman of the Committee on Transients of the Family and Child Welfare Council. W. G. Munn served as both a vice-president and member of the Budget Committee of the Community Chest, C. D. Major was, for a time, chairman of the Chest Budget Committeo, and both Mrs. Halleck and Gustave Breaux served on the Executive Committee of the chest.

For the first year and a half of operation under the name of Family Service Organization, the General Secretary, with the approval of the Executive Committeo, was responsible for the interpretation of relief needs, the effects of inadequate relief, the lack of other resources in the city and its comparison with other cities, with the executive of the Welfare League who, in turn, gave the interpretation to his Executive Committeo. In June 1923, after receiving evidence from the staff of inability to cut relief further to meet increasing demands, the president was authorized to appoint a comittee of four to acconpany the General Secretary in presenting such a resolution to the Welfare League. It proved unnecessary for this special committee to act, however, as the Welfare League was sympathetic to the request for additional funds. 
Correspondence indicates that in 1922 and 1923, in several instances, the Executive Committee of the Welfare League was more conscious of the need for increasing relief funds than was the agency Board. In 1922 and 1923 when the agency was faced with emergeneies necessitating additional relief funds, the Executive Comnittee authorized the General Secretary to exceed the budget and supported his request to the Community Chest for additional funds. Later the General secretary sometimes took this responsibility upon himself, later reporting to the Executive Committee and Board for their approval.

When the Chest compaign of 1924 failed to reach its goal and the agency was asked to indicate what budget cut was possible, a special committe appointed by the president, after securing from the General secretary an outline of possible economies, drafted a statement that savings could be made only by seriously curtailing services; this statement was signed by the entire Executive Committee. In June 1924, with the financial situation still critical, the Executive Cormittee re-opened the question of curtailing function. All suggestions of curtailment of relief and service were dropped as impracticable or dangerous. It was the consensus of opinion that the agency should not reduce its expenditures until it was directly requested to do so by the Community Chest, at which time the Chest "should assume its portion of the responsibility" in determining how and to what extent relief and other assistance "should be refused to families in need."

In 1925 the Chest campaign fell $\$ 30,000.00$ short of its goal. The subsequent cut in the society's budget again stimulated examination of 
function and renewed the question of the society's responsibility when the Chest failed to provide the funds considered necessary. The only city provision for relief during the year was six hundred tons of coal. The agency had cut off its work out side the city limits, but this relieved the budget only slightly.

In May 1925, the Case Policy Cormittee ${ }^{9}$ met with several staff members to discuss possible oconomies. As a result of discussions by this committer, the Executive Committer and the Board, a statement was approved on July 31, 1925, for issuance to the Community Chest over the signatures of all members of the Case Policy Committee. After outlining that the society's steadily increasing expenditures and current overdraft in budget were due to increased living costs, wider knowledge of the agency's services through campaign solicitation, the lack of public relief, inadequate institutional facilities, increased unemployment, and an effort "to meet human needs decently, recognizing that relief in the past had been inadequate," the statement then gave evidence that the problem was country-wide and compared the per capita giving in Louisville with other cities. With this background, the concept of responsibility of the chest was stated as follows:

"The Family Service Organization feels that its prime responsibility is toward those in need in the community. It is the responsibility of the Community Chest to decide whether or not sufficient funds will be available

9. The function of the Case Policy Committer was "the consideration and decision of all major questions of policy affecting work with families, subject to the approval of the Executive Comittee or the Board in matters affecting the public or financial standing of the organization." - Statement of Comittees and Duties by the President and General Secretary, 1924. 


\begin{abstract}
for the organization to meet this responsibility. We respectfully urge that some means be found to meet the demands without drastic cuts; such cuts, we believe, would result in severe suffering in the community and would react very unfavorably both upon the society itself and upon the Community chest. Inadequate relief simply piles up problems on the conmunity. We believe the chest should be asked to accept the responsibility as to whether or not we must curtail.

"If relief is to be curtailed, it is believed that the Family Service Organization should refuse relief in cases which should be a public responsibility, namely: aged singles, aged couples, chronically ill, unemployed, disabled ex-soldiers, widows, feeble-minded and epileptic. We urge that this drastic action not be taken."
\end{abstract}

The Executive Committee did not wait for formal approval by the entire Board but followed this statement by a meeting, on July 13, 1925, with the Executive Committee and Executive of the Community Chest which resulted in the chest roting to permit the society to exceed its budget by $\$ 13,541.00$.

The question of publicity was repeatedly an area of conflict with the chest, for the laymen identified with the agency resented the responsibility for meeting all needs being placed on the society, if, in turn, the society was not free to inform the public as to the facts. In April 1926, the Case Policy Committee recomended to the Executive Committeo that more publicity be given to the society's work and that a letter be sent to the Community Chest asking for publicity about the deficit in funds.

In May 1926, the Board was notified that another budget cut was necessary. The Case Policy Comittee, after meeting with the executive and supervisory staff, presented to the Board three possible 
plans: (1) the shutting down of the organization for two months;

(2) for the rest of the year reducing the staff by one-third plus cutting off certain cases; or (3) rofusing relief to the following cases: the aged, the unemployed, the single chronically ill, those with some income even though inadequate, and dependent widowed mothers. The Board directed that a conmittee of the Executive Comittee take the proposals to the Chest with the result that the Chest granted an additional. $\$ 4,000.00$. Since this was recognized as only a partial help and since the St. Louis agency was believed to have worked out a satisfactory plan, the executive of that agency was asked to meet with the Board, the General Secretary and supervisors, and the executive of the chest to work out plans for reducing case loads in line with the st. Louis plan. A modification of that plan was worked out, and was prosented in detail to the chest.

In January 1927, during the Chest campaign, the Executive Committeo authorized publication in the press of a statement making clear the importance of reaching the goal, and that the agency could not be held responsible to meet all requests if sufficient funds were not raised. At the same time a comnunication was sent to the Chest again outlining the situation the socioty was facing. This was the beginning of a trend for the Board or the Executive Conmittee frequently to request the General Secretary to use more publicity about the society's work and the relief situation in the community. The first quarter of the year was always a difficult period for the society, for the demands were heavy; yet there was insecurity since the final annual budget was 
not approved until after the campaign, which was usually held in January or February. To meet this situation in 1927, the Case Policy Comitteo recommended that a joint meeting be held with the Executive Conmittee of the Chest to ask permission to spend an additional $\$ 5,000.00$ to cover the period through March, with the understanding that if this amount had not been absorbed in savings during subsequent months, it would be met by the chest.

Late in February 1927, when conferences with city officials made it appear certain the city would make an appropriation to the Chest for the benefit of the agency, the Board decided that no drastic linitation of intake would be made for six weeks. It is significant that when this income of $\$ 5,000.00$ materialized, it was spoken of by the Board as a "gift" from the city. The statement was also made that that appropriation coupled with the $\$ 5,000.00$ additional allowed by the Chest had cleared up the deficit resulting from the "unemployment emergency of the past winter."

Toward the end of 1927, there was increased evidence of a gradual change in thinking on the part of the Board as to definition of function of the society. The Case Policy Comittee and the Executive Comitteo were authorized to work with the General secretary in deciding what classes of applications should be refused and what cases should be closed in order to meet the relief situation. By November, the Case Policy Committee recomended that if the Community Chest did not allow additional needed funds, the society would have to reduce case load, carry over unpaid bills, borrow the money, or make another 
request to the city for funds. The last plan was carried out, and on Decomber 5, 1927, the society was notified that the city would appropriate $\$ 15,000.00$ to the Chest for 1928 .

The Board because of previous experience with excess spending, deficits, difficultios in securing refunds, etc., enunciated in March, 1928, a policy of living within the budget while continuing to attempt to get increases in the budget. A ruling that the budget for any one month might not be exceeded without the authority of the Board after securing approval of the chest was frequently discussed although not formally passed.

The trend toward delegation of responsibility was evident in the field of inter-agency policy, although the Board took much responsibility in working out policies with the Community Chest and in developing new resources. The earlier eagerness to take on new activities and to furnish investigational service to many agencies and institutions gradually began to give way to the effort to define and limit function. The work of the Health, the Family and Child Welfare, and the Recroation Councils of the Community Chest was a strong influence toward coordination of both lay and professional activities. In many instances it was the General Secretary who was delegated by the Board to work out interagency policy. In earlier periods it seems likely that the request of the Board of Public Safety for a representative to serve on a comittee to make a survey of the needs and facilities of certain city institutions would have been met by Board representation, but on November 21, 1923, the Executive Committeo authorized the General Secretary to represent 
the society. In a few instances, Board wembers continued to carry this responsibility. Mrs. L. E. Riddell gave much time to the survey which laid the ground work for organization of the Calvary Point Community House and became a member of that board. In 1927, Mrs. Louis Seelbach was chairman of the Transient Committer of the Family and 10

Child Welfare Council of Chest. The same year the Executive Committer meeting with the Board of Education regarding the furnishing of school clothing by the society resulted in the formation of a joint committeo of the two groups to work out plans. Fostering of better relations with and interpretation to church groups centered in the staff rather than in lay groups, except for the part played by Board member, Rev. E. C. Lucas, as joint chaiman of the Committeo on Cooperation between Social Agencies and Churches of the Louisville Conference of Social Work. In December 1922, the Executive Comittee and the Board decided that $\$ 1,500.00$ in the budget allotted to the county worker would be diverted to employing a child placing worker. Much of the territory covered by the county worker had been brought within the city limits and the society saw the noed of a child placing worker for families al ready under the care of the society. The committee believed, however, that the society should not have a permanent Child Placing Department and looked forward even in starting this work to its being taken over by another agency. This development took place in 1924 when the Children's Bureau was organized as a Chest ageney. The Case Policy Committee decided in 1924 that no set policy should be adopted regarding non-resident families but that each situa- 
tion should be considered on its merits. The society's responsibility to assist elderly poople owning property was also considered, and on June 10, 1924, the Board approved the plan recomended of approaching banks or tmast companies to advance money on mortgages on the homes of aged persons, with or without resources, under the care of the society; the money so adranced to be put in a special tmast fund held by the bank and administered for the benefit of the aged person by the society. This committee also made a survey of the private homes for the aged in the city. Advice was given to the staff regarding Christmas giving to clients.

In inter-agency policy the Executive Comittee made an important decision on April 26, 1927, when it authorized the General Secretary to notify other agencies that the Family Service Organization would no longer meet expenditures for material assistance for their clients "except in exceptional cases." This policy, however, was not put into effect until the following year when the Executive Committee met with representatives of the six agencies who had been calling upon the agency for relief for their clients and worked out plans for the emergency fund from the chest to be pro-rated directly to those agencies instead of coming through the society.

In July 1927 one member of the Board was delegated to work with the General Secretary in interviewing various community persons as to better handling of desertion and non-support cases. In 1927 and 1928 , the Executive Committee again tried unsuccessfully to get the Board of Education to take some of the burden of relief for needy school 
children from the society. Another unsuccessful effort to get additional funds for the society was directed toward interesting the Junior League in placing funds that organization might have at the disposal of the society. B Board comittee was unsuccessful in securing reduced rents for society clients from the Real Estate Board but secured some saring in relief funds by arranging for use of grocery books with one large chain store.

\section{c. PLANNING FOR PUBLIC WELFARE}

Activities directed toward development of public responsibility and services were often so fused with efforts to secure funds from the Community Chest as to make it difficult to separate the two areas. Several incidents of appeals to city authorities have al ready beon mentioned.

One of the first indications of awareness of the effect on the agency of inadequate public resources resulted in an interesting decision to subsidize public facilities. On April 17, 1923, after interprotation by the ceneral Secretary of the cost to the agency of fifty individuals, aged, infirm and crippled, or chronically diseased, not eligible or acceptable to any existing institutions in the city, the Executive Committeo authorized the making of an agreement with the city for the agency to hire an attendant, at a cost not exceeding the cost of care of those persons, to be placed at the Home for the Aged. In return for this service, the Home would be asked to accept a number of cases, hitherto refused, of individuals who would be placed under the care of such an attendant. Records do not reveal the outcome of the decision. 
Repeated interpretation by the General Secretary of the agency's inability to meot all the needs in the community and the neod for development of public resources brought at first, on the part of the Board, a questioning of the ability of private funds to care for long time needs rather than a conviction that any particular group was the logical responsibility of the public. Although the state and Louisville conferences of social work agitated for tax funds for relief, there was littlo support by lay groups. This lag seems at loast in part the responsibility of the private agencies who had for so long sold themselves to the public as all encompassing, and even though professional workers were beginning to proclaim the need for public funds, they still warned against the dangers of political administration.

The reluctance of the Board to refuse any requests is illustrated by their action on September 11, 1923. The General Secretary asked for a resolution indicating the society did not have the "facilities or resources to provide adequate care for dependent chronic invalids, convalescents, and drug addicts" and that "such care is or should be the function of public institutions," and for authorization to refuse to accept responsibility for any such dependents "upon the opinion of a roputable physician that the applicant is or should be an institution case." While there was general approval of the purpose the staff wished to achieve, "many members felt it should not be sought through limitation or refusal to accept cases" which would "seriously injure the public reputation and the work of this organization and the Welfare League." 
Two months later, upon information from the General Secretary as to the urgency of inducing the City Council to make an appropriation for relief, the president was authorized to appoint a committee to present such a request. Thus was created the Comitteo on City Cooperation, which as its function grew, was sometimes referred to as the Cooperation Committee. There is no report as to efforts or success of this committee for some time, but on February 11, 1924, it was asked to take up with the proper authoritios the question of re-imbursement for clothing for needy children given by the society on recormendation of the Attendance Department of the Board of Education. This was evidence of a desire to change a practice of years standing although it is not clear whether it was recognized as evidence of clarification of public responsibility or merely as a means of conserving society funds. The questions of city coal allotted to the society and of pauper transportation were also referred to this committee. In January, 1925, the Case Policy Committer again discussed the problem of care of aged couples, and it is significant that the comittes's thinking seomed directed only toward securing adequate institutional care, although only a year later state legislation for Old Age Pensions was passed. Although the Board had decided in 1922 to use the funds allotted for county work to establish the child placing work, county work had continued. On Narch 17, 1925, as a means of meeting mounting rolief costs and excessive case loads, the Board decided after April 1, 1925, to eliminate all work in Jefferson County outside the city limits "unless the Community Chest signifies its objection...... and its 
intention to furnish the additional funds necessary to carry on the existing pressure of work." This question had al ready been discussed with the County Judge who indicated that if the society gave up its county work, the county authorities would meet the situation as best they could. The Board felt responsibility for these families and a special committee was appointed to interview county authorities regarding adequate arrangements for carrying on the work. It was not until these plans were studied that the General Secretary discovered that the carrying of county work at all had boon unconstitutional. The spocial committee was unsuccessful in persuading the County Commissioners to employ a county welfare worker.

Material from other cities, from the national organization, and from the society itself interpreted by the General Secretary to the Board and its comnittees gradually brought about some change in thinking. One of the first statements of policy of E. S. Tachau, after his election as president of the Board in 1925, was that one aim should be the persuading of governmental agencies to assume further social responsibility. In a letter to President Tachau on June 10, 1925, B oard member and past president, W. G. Munn, comented on the proposal of the Case Policy Committee to cut off certain groups: "It may sound hard-boiled, but it seems to me the groups shown (on the memorandum) a re really wards and charges of the city and should be taken care of and provided for by taxation." And at the meeting of the chest and agency executive comittees which resulted in the additional allowence to the agency in 1925, sentiment was expressed by a member of the Chest board that 
"people must agree to be taxed for work of this nature." A movement was agreed on by the two executive committees to try to get both political parties to include such a plank in their platforms at the forthcoming city election, and it was also agreed that more information should be given to the public regarding the inadequacy of chest contributions to meet all needs.

Later in 1925 the president of the Board and the chairman of the Cooperation Comittee secured the city's consent to continue paying for "pauper" transportation. In July, the Executive and Cooperation Committees held several meetings with the Board of Safoty concerning the need for public relief. In August a small group of the Board met with one of the candidates for County Judge to discuss the boarding of children with their own mothers out of public funds and the need for trained service in the Juvenile Court, and in November another special comitter met with the new hayor to present the society's noods. The Board also took responsibility periodically for attempting to secure additional city services. On April 29, 1926, the prosident of the Board and the president of the Community Chest met with the Mayor and worked out a plan for the city paying the salaries of employees of the dental clinic and the City Hospital Social Service Department, in addition to continuing to supply city coal and paying for "pauper" transportation. Later in the year, the Committee on City Cooperation tried unsuccessfully to interest city officials in appropriating money instead of city coal. These numerous conferences between the Mayor and representatives of the society apparently did much to convince city 
authorities of the reliability of the agency's work and later influenced city authorities to appropricte funds to the Chest for the agency. Throughout 1928, various groups of clients were singled out by the Case Folicy Comritter for study as to their cost to the society, the need for securing additional funds for their care, or the possibility of referring their care to some other agency. In referring study of the aged and the ex-service man to the Case Foljcy Comittee in March 1928, the Board indicated its conviction that both problems should be discussed with the city administration, and conferences between the Executive Committee and the Chest Board with the liayor were held to attempt to secure additional appropriations from the city. In July 1928 the Case Policy Comittee asked that the Health Council of the Chest be informed the society could not continue to provide for dependonts suffering from cancer, as they should te a comunity responsibility. After the Mayor requested reconsideration of this decision, the Board did not agree to this recomendation. In October, the Executive Committee recliested that the Social Planning Committee of the Chest consider the whole question of dependency caused by cancer.

In October, 1928, in order to attempt to live within the budget, the staff made drastic relief cuts. On October 16, 1928, the Case Policy Committeo recommended to the Board that "vigorous steps" be taken to get an appropriation from the city and that a committee go to the Chest, and to the liayor if nocessary, in order to bring this about. It further recomended that the General secretary prepare a statement concerning the financial situation of the socjety for the press. Regarding the drastic relief cuts the comittee stated: 


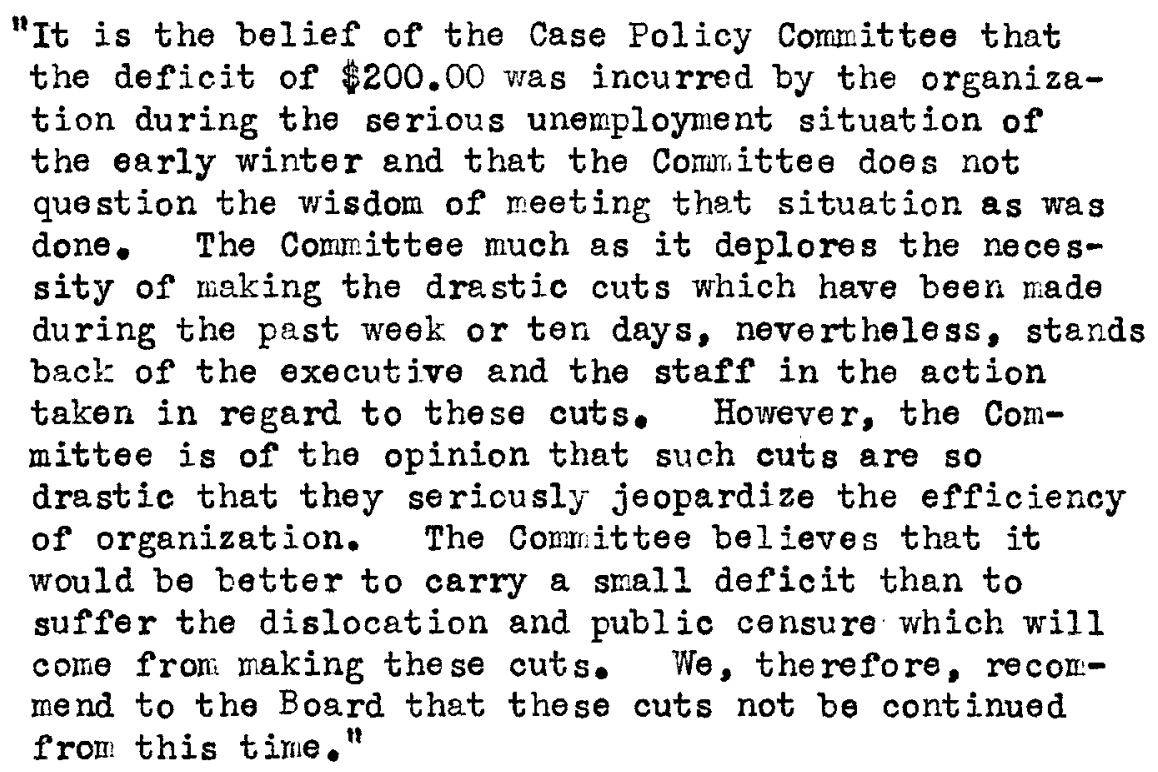

The Board upheld this recomendation and so informed the Chest. Definite change in thinking had come about during this period. It seened evident the Board still lagged behind the professional staff in willingness to limit the function of the society but had made progress from its earlier unwillingness either to seek public subsidy or relinquish any services. Philosophy regarding public responsibility for relief had changed because of the urgent need for additional sources of assistance, but only a small group was yet ready to think in teras of the city expending its own relief funds. That step was delayed until the following period. Legislation

There was a significant lessening of activity in the field of legislation and further evidence of delegation of responsibility to the staff of activities fomerly carried mostly by the Board. The increasing concern for the immediate relief situation and for defining the more limited function of the family agency may possibly have diverted or narrowed interest. The trend in case work toward the subjective led 
for a time too far away from concern for the environment in which the individual was functioning. It is true that sore of the earlier activity had resulted in legislation that at least in part bettered conditions, but there seems to have been a significant lack of awareness of the possibility of providing for sore groups through legislation. It is posible there was somerhat more participation in legislation than is evident from the records.

Although there was mention in 1923 that a Housing Commit tee would be appointed when needed, and in the re-organization plans of 1924 such a cormittee was outlined as important, no such comilttee was set up to continue the efforts to improve housing carried on under the Associated Charities.

In 1922, the Board instmoted the General secretary to wire the Governor requesting him to veto the bill repealing the current housing 1aw. In 1924, after the Generel Secretary brought to the attention of the Executive Committee the bills before the Legislature attacking the State Board of Charities and Corrections and the State Board of Health, the president appointed a comittee of two, one of which was the ceneral Secretary, to draw up a resolution opposing these bills. Similar instruction was given the same conmittee regarding the "Anti-Loan Shark Bill," and a bill to reorganize the State Labor Departrent. The following year one member of the Board attended several meetings on the need for a state institution for the feoble-minded. In 1925 , a commitioe conferred with the County Judge as to the need for passage of a Juvenile Court law by the Legislature. In none of these efforts was there 
evidence of sustained interest or planful active sponsorship of legislation.

In the field of Mothers' Pension legislation, largely because by consent and interest of the Board, the cenerel Secretary was an active member of the State Mothers' Aid Committee, interest was more sustained. In 1927, Board members Grover Sales and H. E. MoElwain drafted a bill providing for creation of a State Children's Bureau and administration of Mothers' Aid under it. Board members actively lobbied for it, and in amended form this bill was passed by the Legislature in 1928. After the permissive law was passed, the Executive Comitteo authorized recommending the law be made operative in Jefferson County. Later in 1928, under the influence of Mrs. R. P. Ealleck, the Board was made aware of the need for study of the permissive Old Age Pension Law in order that steps might be taken for it to become operative in Jefferson County. With the acceptance of Mothers' Aid by Jefferson County in 1928, the Case Policy Committee immediately took responsibility for working out the socioty's policies regarding Mothers' Aid. In Jure, the General Secretary was directed to file immediately "our best cases with Jurenile Court for Mothers' Aid," and to call together a group to discuss with the County Judge the best procedure for handling Mothers' Aid. As a result of this conference, the Case Policy Committee met with the Executive Committee on July 17, 1928, and decided since a tax provision had been made for Mothers' Aid, the society should turn over such cases to the Louisville and Jefferson County Children's Home as soon as possible. Thus a beginning was made in eliminating one category of cases from the function of the Family Service Organization. 
Employment Services

Citizens were active also in various efforts to secure coordinated action in the handling of employment services. Col. Henry L. Stites, as chaiman of the Employment Committee, was active in stimulating thinking of the Board as well as participating in various comunity meetings. In November, 1925, an informal group made up of representatives of the American Legion, the Board of Trade, the Family Service Organization, the Consumers' League, and the School of Social Work met to consider initiation of an employment bureau, as there was in operation only the State Employment Bureau which was considered inadequate to handle the situation. The group considered whether it would be advisable to initiate such a bureau as a private venture, with money contributed by various agencies from their budgets, looking toward eventuel public support, or whether it should be developed from the beginning as a public bureau. On November 25, 1925, they recommended that such a bureau be organized. "The bureau should be organized independently from any branch of the government or any private organization, Community Chest, or otherwise, but it may accept financial aid from any branch of the government or any organizations or interested individuals." This recommendation was not carried out but meetings of this and other groups continued during 1926. On Jenuery 7. 1927, Col. Stites called a meeting of the Employment Committee with guests from the American Legion, Board of Trade, and the Y.M.C.A. Two sub-comittees were established, one to deal with the current emergency, the other to deal with the problem from a permanent standpoint, with membership drawn from the agency Employment Conuritter, the Board of 
Trade, the American Legion, and the Y.M.C.A. Col. Stites had several conferences with the layor. The permanent conmittee studied possibilities for stabilizing employment and for temporary work during periods of unemployment, and made a survey of the employment offices and agencies operating in the city. A special sub-cormittee studied the possibilities for establishing a permanent bureau. On January 14, 1927, Col. Stites and the General Secretary gained the liayor's promise to start immediately city projects planned for a later time. The various committees then asked the society to set up from its personnel a temporary free employment bureau until sone more permanent plan could be made. On January 28, 1927, the Executive Committee authorized the reorganization of the staff so this could be done, stating: "This is an emergency measure caused by the large number of unerployed and is only temporary until a permanent free employment bureau can be established." The Employment Committee secured the cooperation of the Board of Trade in writing employers urging use of the society's employment bureau and in interpreting the unemployment situation. The Case Policy Committeo was active during this period in urging that the community be made aware that the society alone could not handle the unemployment situation. Meantime, the sub-comrittee on a permanent employment bureau, after drawing up plans, asked Col. Stites to call a meeting of the Employment Committee, the Board, and other citizens to consider its recommendetions. At such a meeting on April 28, 1927, the Board was requested to continue the society's employment bureau until a permanent bureau could be established. In August 1927, the United States Employment Service asked 
the Committee on Permanent Employment Bureau to form an advisory committee to cooperate with the local representative to ralice that service as effective as possible and to act as a part of the board of the public employment office.

In January 1928, Col. Stites met with the Nayor to try to work out plans for the winter. Various groups continued to neet but no plans were consummated, and in February the society again organized its own employment bureau. On July 6, 1928, the Board brought together the Employment Committee, representatives of the Conmunity Chest, the Board of Trade, the YM.C.A., and the Nayor's Office to consider again possibilities of establishing an employment bureau. The recomendations of the previous year were considered, and it was decided to refer the subject to the Community Chest, and if the Chest failed to provide the necessary funds, further attempts to set up an independent bureau would be made. An Employment Committer of the Family and Child Welfare Council of the Community Chest was established with several members drawn from the society's Employment Committee. After several meetings this committee recomended the Family Service Organization should establish a free employment bureau, which was felt to be a necessary agent of the service of a case working agency." The Board, on October 24. 1928, gave general approval but asked for further study as to the possibility of securing an increased appropriation for the federal employment office. A week later, a joint meeting of the Executive and Employment Comittees of the Family Service Organization and the Employnent Committee of the Chest was held. The decision reached was to ask 
the Governor to ask the United States Employment Service to increase its service, and to request the Chest to allow the Fanily service Organization $\$ 3,000.00$ in its budget in order to set up a bureau, and to deterwine what assistance might be secured from the state. At a meeting on November 10, 1928, the following groups were represented: the United States Employment Service, the Board of Trade, the State Departrent of Agriculture, Labor and Statistics, the Community Chest, the Nayor's Office, the Family and Child Welfare Council, and the Family Service Organization. The decision was reached that an employment bureau be organized to centralize all employment activities, national, state, county, and city, with a carefully chosen citizens' comritter in charge, financing to be by contribution of all participating groups. The year 1928 ended with plans boing made to bring this about, and the society included in its 1929 budget request an item of $\$ 3,000.00$ for its share of financing. These various independent efforts growing out of the concem of several groups culminated in concerted action by a large body of laymen to pool all the possible resources to meet the problem. The deliberations of the various committees gave evidence of an increased admission of both the size and the continuous rather than energency and temporary nature of the inemployment problem.

\section{OTFER COMN ITTEES}

Home Economics

Although the Home Economics Department, begun during 1921, was continued until April 1925, there is only slight mention of the Home 
Economics Conmittee. During 1922, several reports were given of the cormittee's work in consulting with the Home Economist. Building Committee

In epril, 1922, the Building Comrittee was given responsibility for devising ways and means of increasing the available space for the various agencies housed in the Social Service Building. After study of the present and possible future needs of all the agencies, the committee was directed to draw up plans for remodeling the Wayfarers' Lodge. It worked closely with the General Secretary but records do not indicate clearly just how responsibility for plans, bids and contracts was divided although it is clear comittee rerbers gave much time to the responsibility.

To give the Building Cormittee the necessary authority to proceed, the Board on September 19, 1922, ordered: "The Building Committee is he reby authorized to establish a special Building Fund, the account for which shall be kept by the bookkeeper, out of which to pay the expenses of remodeling the Social Service Building and the Wayfarers' Lodge..... and to designate one of their number as Treasurer of said fund. The Treasurer of the Family Service Organization is hereby authorized and directed to turn over to the person so designated.....ell of any portion of the money in the bank belonging to the Investment Fund, and such securities of the Family service Organization as he may deem the most advisable to sell, to the approximate total of $\$ 7,000.00$. The Treasurer of the Building Fund shall draw checks on said Fund for the above purposes, upon presentation of vouchers signed by the General secretary 
and approved by the President or the Chaiman of the Building Committeo, the total not to exceed $\$ 7,000,00 . "$ A later order of the Board increased the amount to $\$ 9,000.00$.

The earlier House Conmitteo made decisions about maintenance employees and had authority to nake emergency expenditures up to $\$ 100.00$ for repairs. Larger contracts were presented by the committee to the Board for authorization. These duties were later taken over by the joint Building Comitteo. Responsibility for building managenent and operation was carriod in whole or in part by this committe日. At various times the chaiman was in almost daily consultation with the General Secretary. In 1926, the committee was active in advising as to the wisdom and selection of a district office, and in 1928 after general satisfaction with the Portland district office, was asked to study the advisability of setting up another district office. In all of these duties, the committee both relieved the professional staff of time consuming responsibilities and offered technical advice and skill not possessed by the professional staff.

Volunteers

In the 1924 outline of "Stateneint and Dutjes of Comittees," provision was made for a Committee on Volunteers. "One of our weaknesses at the present is a lack of contact with the commuity through a sufficient use of volunteers. We should serve as a channel for energy and interest of many women who are able and willing to be of personal service to the unfortunate. This comittee will, therefore, secure volunteers to assist in the various phases of our wo k, carefully selecting them according to their individual fitness and adaptability 
for the work, and by assigning them and assisting in their training and superrision." Until the emergency of mounting case loads, however, there was only minor use of volunteers in horie visiting. While the Home Economics Department was in operation, it used volunteers from the Baptist Training School Settlement in home visiting to teach housekeeping and cooking, according to the roports of that department, with excellent results. Volunteors from the District Comittees assisted in investigation of families for the Christmas clearing Comititee in 1926. The supervision and planning of volunteer activity was scattored among the District Supervisors, rather than the Volunteer Comitteo, during the early years of the Family Service Organization. As early as 1926, a few volunteers gave clerical and notor services, and one or two selected volunteers occasionally did some home visiting. On April 10, 1927, the General secretary suggested the creation of a Volunteer Department for meeting the need of school clothing and the instructing of mothers in the essentials of home making and sewing. This service had been started on a small scale by a group of women from St. Narks Church. This suggestion was carried out by appointing Philip Ewald chairman of the Committeo on Volunteers. The comittec first made a survey of all the types of work that might be done by volunteers and the number who might be used. By September 1928, there were nine to ten fuj.l time volunteers on the stafe, in addition to others giving part time to visiting, clerical work and motor service. There was a distinction between the two groups both in their interest and in the agency philosophy concerning them. Nany of the full time volunteers were interested in 
securing paid positions and both they and the society considered their service as an apprenticeship period. The society was pressed by the neod for additional staff and there was neither adequate salary budget nor sufficient workers with training from which to draw. It is not possible to judge how much it was possible, as pressure of case loads mounted, to keep clear any philosophy about the use of volunteers or how much they served merely to get work done which an overburdened staff could not do. It is evident, however, that out of the group of voluneeers of that period were drawn several staff members who continued with their training and experience.

A volunteer group not a part of or created by the society, but cooperating with it, was the Crescent Hill Social Service Committeo. This comittee, composed of three mernbers from each of a group of Crescent Hill churches, met twice monthly, and in 1926 asked that a staff member be assigned to work with them. The society kept a careful rocord of the activities of the comittee as they touched the work of the agency. lany contributions of money and clothing we re made to agency clients and occasionally the comittee took over complete responsibility for a particular family. In June 1928, the District Supervisor reported: "The hardest part of our contact seems to be in making the committee members realize that our need for them is more for service than for relief.....We have urged that they do friendly visiting in certain cases, helping with advice in homemaking and giving encouragement to certain fanilies who seom particularly down-hearted and in need of more contact." 
Annual Meetings

The decrease in interest in the annual meotings of the socioty evident during the Associated Charities era, continued during the first years of the Family Service Organization, so much so that in 1924 two ineetings were necessary because the first failed to bring out a quom. While the program offered opportunity for participation of officers and comitte chairmen in making reports, there was so little interest that only a small group of the general menbership attended, and the re was no participation of that membership except in the rathe $r$ routine voting on resolutions, and the customary unanimous acceptance of the Nominating Comitte日's selection of new membership for the Board. The 1924 and 1925 meetings reverted to a program sonetimes used in fomer years of presentation by staff members of their work. Beginning in 1926 there was a changed approach to the annual me日tings with a resultant largo increase in attendance. The meetings were held at luncheon or dinner; there was increased publicity; specific invitations were issued to contributors and Community Chest campaign workers. Although leadership in planning, and selection of an outside speaker was left with the General Secretary, Board members were active in carrying out publicity, in arranging for the dinner, selling tickets, etc. At only the 1926 and 1929 meetings were out of town leaders in social work the chief attraction of the program with minor emphasis on reports by officers and comitteo chairmen. In other years, the older form of staff and Board participation was followed. In 1928 the plan which had proved so successful in the earliest days of the society was followed of building 
the meeting around participation by community persons that would indicate the cooperation between the society, other agencies, churches and volunteer groups.

\section{SUMARY}

Coordinated social planning was more evident in this than in earlier periods. Many activities formerly initiated and directed by the Board and its committees were taken over in whole or in part by the Councils of the Community Chest. Except in the field of Mothers' Aid legislation, employment services and a few other scattered efforts to improve or secure public services, the chief concems of the Board and its committees were the securing of additional relief funds and the defining of agency function. The consistent interpretation and pressure by the Board were influential in securing increased appropriations from the city and the Comrnunity chest.

Areas of conflict developed in relations between the Board and the newly organized Comriunity Chest. The Board was reluctant to give up authority, was critical of the amount of funds raised and insistent upon more publicity as to the extent of need in the cormunity. The inadequacy of relief funds was the motivating force behind efforts to Iimit the agency's function. There was a reluctance to give up services, a concern for groups unprovided for and conviction as to the agency's responsibility to the community. Efforts were made to get funds from many sources. Gradually as an awareness developed that the private agency could not rieet all community needs there was acceptance of the need for public funds. A few leaders began to express the 
conviction that relief funds should, in part, be raised by taxation, Thinking and activity was directed, however, toward the securing of public funds for the private agency rather than toward the setting up of a public relief department. The conviction that certain categorical groups were the responsibility of the public was directly affected by the adequacy of relief funds at any particular time.

Many responsibilities formerly carried by the Board and its committeos were gradually delegated to the professional staff. There was almost no participation in the case work of the agency and some withdrawal from responsibility for personnel, although the Executive Committee still retained considerable responsibility in this area. Except with the Chest and city authorities, development of inter-agency policy was largely delegated to the General Secretary. Although direction and coordination of volunteer activity was considered a Board committee responsibility, in practice it was largely carried by the staff. There was a less well defined philosophy as to the use of volunteers and the extent of their use was directly related to the pressure of work and inadequacy of staff rather than to special services volunteers could render to the agency's clients. Participation by the membership in the annual meetings increased toward the latter part of this period. There was a lack of consistent activity by the Board during the first two years when the agency was without a General secretary, and a concentration of authority in the president and the General Secretary for a few years thereafter. These trends indicated the importance of leadership both ley and professional in the developnent of community participation. 
CHAPTER V

THE FAMILY SERVICE ORGANIZATION

$1929-1938$ 


\section{TEE FAMILY SERV ICE ORGANIZATION $1929-1938$}

The decade of the $1930^{\prime} \mathrm{s}$ has been described by Fred K. Hoehler, Diroctor of the American Public Welfare Association, as one that might have been known as "the decade of destitution" but for the humane leadership of the national administration. Unemployment, which had even before the depression increased to such proportions that the private agencies were unable to meet the demands made upon them, mounted with the depression to a degreo that made national action imperative. Mr. Hoehler indicates that "the social philosophy of the man on the street underwent a marked change. The biblicel quotation 'Am I My Brother's Keeper?', so often the query of charity campaigns, was taken off the sign post, brought down to earth, and made the query for every man.... During these years ...much of what really happened for the care of people came from the philosophy of a few pioneers in social work. They saw beyond the narrow concept of charity organizations to a new and more humane responsibility." The decade of the $30^{\prime}$ 's brought an unprecedented increase in public relief expenditures and "a system of local poor relief which had remained practioally unchanged for a century and a half was superseded not only by new methods but by a new philosophy of governmental responsibility for people in need." ${ }^{2}$

1. Naterial for this chapter, except where otherwise indicated, is taken from minutes of the meotings of the Board of Directors, the

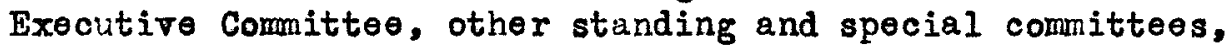
annual reports, reports of the General secretary and the District Supervisors, correspondence, and publicity.

2. Brown, Josephine C., op. cit. 
When the depression threw its impossibly heavy burden on private agencies, they attempted at first to carry the staggering load and to continue to justify the faith of the community in their methods. Attempts wore made to raise spocial funds for private agencies, and public funds were delegated to private agencies or citizens' comitteos. Public relief continued to carry an increasing share of the load. State and Federal conferences and councils increased as the predicted comeback failed to materialize. Throughout the early years, the almost constant use of the words "emergency" and "temporary", indicative of both official and personal philosophy as to the nature of the problem, were coupled with that of "local responsibility" to describe the traditional method of meeting such responsibility.

Although pressure for federal assistance had begun, Congress failed to pass legislation in 1930 or 1931. In February 1932, Congress authorized the distribution of goverment-owned wheat and cotton to the American Red Cross and othe $r$ organizations for distribution. Federal assistance in the form of loans to the states was finally initiated in 1932 as the only relief measure passed during the Hoover administration. In the private field the drives for funds in the winter of 1932-1933 represented the greatest and final effort of the private agencies to carry a substantial share of the costs of unemployment relief. In May 1933, the Federal Emergency Relief Administration came into existence and under the active direction of the Federal goverment, the methods, forms and adequacies of relief were profoundly modified. Although the load of work was crushingly heavy, the influence of federal standards 
and the "drafting" of large numbers of workers from private agencies, particularly for executive and supervisory positions, tended to hasten the adaptation of skills developed in the private field to use in public agenoies. The far reaching policy of the Federal Emergency Relief Administration, which became effective in August 1933, that pub1ic funds were to be administered only by public agencies, brought to a climax the discussion of previous years as to the division in function between private and public ageneies. The break was made less sharp in some instances by private agencies converting themselves into public agencies or by the setting up of separate units of unemployment relief administration within the private agency, but as the federal programs developed, the early hastily organized units, in most instances, developed into establishod departments.

The period of 1935-1939, in contrast to the first half of the decade, was one of development of a permanent program. This change was characterized by a shift from a federal generalized relief administration to a division of responsibility according to categories of need, with the Federal Government undertaking to provide for the employable unemployed through a Federal Works Program, and assisting the states, through grants-in-aid under the social security Act, with their responsibility for the aged, the blind, and children who fulfilled certain eligibility requirements. Separate from relief but a part of efforts to meet on a sounder basis the problem of unemployment was the extension of the social insurance and protective labor legislation. Inadequacy of funds, failure of jurisdictions to take advantage of federal 
programs, and gaps left unprovided for meant, however, the need for continued efforts to provide for large groups of those in need.

Although the decade saw the development of governmental relief rather than private relief accepted as a matter of course, the advent of the federal programs did not immediately convince either the public or the leaders in social work of the adequacy of public care or the possibility of the inclusion of services in public programs. The need for clarifying the relationship between public and private agencies, and of defining the future role of the private agency challenged leaders in social work during this period. With the transfer of much of the load on which private agencies had based their appeal for support for sereral years, there was need not only for re-definition of function, but also for development of new methods of interpretation. The influence of psychiatry with its increased insight into human behavior brought to case work an increased concern for the individual and for the tensions, stresses and strains in family relationships. Emphasis on training increased and with it an increase in facilitios for training. As was indicated in the proceding chapter, after many years of little or no city appropriation for relief, the city in 1927, assisted the agency when funds raised by the Community Chest were insufficient to carry the Family Service Organization through the year. The next city appropriation was not made until the fall of 1929 when effects of the depression began to be felt in Louisville. The city's appropriations for relief at first were usually made to the chest for the benefit of the agency because the city had no municipal organiza- 
tion through which to give relief or service. Sometines appropriations were made direotly to the agenoy. Although prior to this time the city had made general appropriations to the Chest, it gradually came to consider its appropriations entirely for rolief rather than for all the servioes rendered by the Chest. Mothers' Aid had become an established fact with about $\$ 65,000.00$ available in the county for Mothers' Aid.

In January 1930, the Department of Public Welfare began handling investigations for admis sion to the Home for the Aged and Infirm and for city coal orders. By the fall of 1930, unemployment was acute and Community Chest funds totally inadequate. The Family Service Organization set up an kmergency Department. Conferences between the Chest, the agency, and the Board of $T$ rade led to formation of the Nayor's Committee on Unemployment. The city began to give three days' work a week to unemployed men capable of working. The Family Service Organization contimued to carry cases resulting from unemployment if the wage earner was ill and unable to work. As the agency had been compelled to exceed its budget during the sumer of 1930, the city appropriated $\$ 18,211.35$ to the agency that fall. The Unemployment Relief Buroau of the Department of Public Welfare, later called the Municipal Relief Bureau and finally the Municipal Bureau of Social Service, was opened November 11, 1930. Investigations were made for assigmments for work relief. Until 1933, the Bureau carried on a work relief program only during the winter, and cases were seasonally transferred botween the Bureau and the Family Service Organization, as city author- 
ities felt it was cheaper to give relief through the private agency than to maintain the Bureau. In botb 1931 and 1932 the eity and the county appropriated large sums to the Chest to meet the expense of unemployment relief through the Family Service Organization. In the fall of 1933, with the grant of Federal funds, the Bureau was made the local agency for administering unemployment relief and carried on work with both federal and local funds. The city continued to subsidize the private agency to earry families who could not be cared for through the Municipal Relief Bureau, and for a short time the agenoy was made a department of the publie agency, in name, in order to continue receiving federal funds through the Kentucky Relief Commission. The private agency also supplemented public agency funds with orders for government flour and clothing to public agenoy clients. The year 1934 saw the re-organization of the Municipal Relief Bureau, the increasing "loan" of workers from the private agency, and conferences regarding transfer of other than unemployment cases fron the private to the public agency. In 1935 the Pamily service Organization began the transfer of families waiting for Mothors' Aid and long time dependents to the Municipal Relief Bureau. With the termination of the Federal Emergenoy Relief Administration in 1935, and the transitional period before the Works Progress Administration and old Age Assistance began to function, applications at the private agenoy increased, but the Board and staff was convinoed the private agency could not again enter the unemployment fields. Efforts to persuade city authorities to take over more responsibility for relief through 
the Bureau continued as city appropriations began to be reduced. Locally, this period terminated with a change in city administration, increased curtailment of public subsidy, further clarification of function between public and private agencies, and increasing transfer of responsibility to the public agenoy.

\section{A. ORGANIZATION AND STRUCTURE}

Constitutional revisions of 1928 operated throughout this period. The standing committees functioning were: Executive, Finance, Building, Caso Policy and Publicity.

The Borrd

Central authority contimed to be rested in the Board of Direotors and to be delegated in part to standing and special committeos. In the organization of committees, the General Secretary exercised influence but was not dominant. The Ceneral Secretary and president usually conferred as to the best membership for a particular comitteo; sometimes the advice of other Board members was sought, and the make up of any committee was usually the result of the thinking of several porsons. Sometimes the president, at other times the Ceneral Secretary, notified the members of appointment and took responsibility for calling the committer to action.

The Executive Committee of the Board, the central policy-making group since the beginning of the agency, ceased to meat after July 1931. This change was not brought about by any formal ruling of the Board, but rather was the result of several factors that led to the committes's being calling together less frequently at first and finally being 
discontinued. There had been a change in both Board president and General Secretary; the agency was faced with almost constant emergencies; the president's philosophy was one of participation and activity by the entire Board, and it was generally agroed that no portion of the Board any longer needed educating by the rest and that in the face of omergencies it would be wise to have action of the entire group. The Board, therefore, agreed to come together whenever necessary and to call the Executive Comittee together only when it was impossible to get the others. While the Executive Comitter was still used, it passed on the annual Transportation agrement, approved the action of the Finance Committee, made suggestions for filling racancies on the Board and contimued contacts with the Commuity Chest and city authoritios.

Membership for the Board was carefully considered by the Nominating Committer. On one occasion in 1934, the committer met with the president and the executive of the Community Chest for suggestions of membership material in the community from whom a new prosident might bo drawn. Vacancies continued to be filled at times throughout the year. To foster contimed responsibility the Nominating Comitteo was changed in name in 1934 to Nembership Committee. Procedures varied from time to time; sometimes the approach to nominees was made by the liembership Comittee, at other times by some other Board member; often the approach was made only after vote of the Board, at other times, the prospective member was approached before his name was presented to the Board. The usual procedure, howrever, was for the lembership Comitte日 to notify the Board in writing that certain persons were being considered and 
would be approached if the Board had no objeotions; after this was carried out, the conmitteo reported at a regular Board meeting, members were approved and the final vote was taken at the annual moeting. In the beginning of this period, Nominating Committer discussions indicate attention was given to geographical distribution of Board members and to representation of various groups. In 1930 the Board weighed the advisability of adding persons who were in elose touch with the Community Chest. In 1933 there was evidence of some differences of opinion as to the type of persons to be selected, and the General secretary was active in pointing out the importance of selecting persons free to speak and act for themselves, On December 15, 1936, after the Board had received a request from the Colored Advisory Comittee for Negro representation on the Board, it enunciated its policy as to selection of membership as follows: ".... it hes not in the past and does not wish in the future to bind itself by agreeing to have representatives from any group, racial or religious. Fach member of the Board is selected on the basis of his individual contribution rather than that he is to speak for any group." The same year the Board considered whether a policy should be adopted of requiring Board members to serve on District Conferences. It was agreed that such experience was highly valuable but that such a policy might block the selection of some persons who could give services to the agency but would not be able to give the aditional time to District Conference work. Throughout these years the General Secrotary was very active in of fering suggestions as to Board membership; the Membership Committee, howerer, was often independent in its selections. 
The Board continued monthly meetings, except during the summer, in addition to specially called meotings. The trend of major responsibility for material presented at Board meetings being carried by the General secretary continued. Case material was presented very infroquently.

Responsibility for personnel policies, in the early years of this period, was not clearly divided between the Executive Committee and Board, and on some occasions recommendations were referred to the case Policy Committee. In whatever way responsibility was divided, Board members, whether acting as a group or through these committees, participated actively in personnel matters such as leaves of absence for the General secretary and Case Supervisor, the employing of workers for new activities, the filling of the positions of General secretary and Case supervisor and the salaries offered, attendance of the General secretary at out-of-town conferences, and loan of workers. In Decenber 1928, the Board ruled the ceneral secretary should not leave the city without permission of the president of the Bosrd, but three months later abolished this ruling. In 1930, when Mr. Benjamin resigned as General Secretary, three members of the Board served as a comittee to fill the vacancy and arranged for the Case Supervisor to act for six months. This committee carried on correspondence with the national organization and applicants, interviewed prospects, and in December 1930 recommended that the acting General Secretary, Miss Esther Taylor, be appointed. Salary schedules and employment of workers were frequently considered by the Board of its committees. On February 7, 1930, the 
Executive Committee decided that funds for extra staff to meet the emergency load of work should be taken from any extre funds received from any source. In april 1931, the Board authorized the payment of a higher selary in order to secure a qualified case worker. In May 1931 it voted to inerease a supervisor's salary in order to retain him but did not change the whole salary schedule and referred the matter of salary schedules to the Case Policy Committee. On the basis of statistical material presented by the General Secretary, the Board in February 1935 approved the employment of an additional Negro worker for a three months' period, the salary to be drawn from the agency's special fund, and later continued the plan for another month. After the 1937 flood, the Board authorized the use of some special gifts, received at that time, for aid to some of the staff who had had flood 10sses. In June 1937, after the General secretary's presentation of the training and experience of all professional staff members and the problem of keeping workers or making replacements because of the salary schedule, the Board approved increasing the salaries of case workers when the General Secretary felt it advisable and after consultation with the president, and the restoring of the Case supervisor's salary to the level prior to reduction a few years earlier. In some areas of personnel policy where authority had previously been exercised, the Board delegated responsibility to the General Secretary. In September 1930, the question of dismissal of a worker was left to the judgment of the ceneral Secretary, and in 1934 when a worker who had been dismissed appealed to the Board, it articulated its policy of non- 
interference with the ceneral Secretary on personnel matters. The same year the General Secretary worked out a plan for re-organization of the districts and changes in salary schedule which was later approved by the Board. During the emergency in November 1930, the General Secretary increased the staff and requested additional funds from the Chest which were granted, then reported to the Board the re-arrangement of district responsibility and the establishment of the Emergency Departrent; the Board approved the continuance of this plan.

Although a nucleus of about one half the Board was in regular attendance at meetings, some members who were not able to attend regularly gave much time to special activities and to advising the conoral Secretary. This constant support of the professional staff during difficult poriods, almost none of which is recorded, played an importand part in carrying the agency through the difficult period of carrying hoavy responsibilitios and gradually transferring responsibility to the public agency. Whenever it was essential to action, such as approving the sale of property, the full Board responded. The Constitutional provision for dropping of Board members after absences from four meetings was never carried out, but those who neither attended nor gave any service wero dropped when their terms expired.

Board members individually continued to accept responsibility outside the agency itself. There was active participation in the annual Chest campaign for funds and as representatives on the Councils of the Chest. In 1932 Mrs. Charles Semple participated in the League of Women Voters' study of the Jefferson County Welfare Department; 
the following year Grover Sales represented the Board on the Louisville Relief Committer of the Kentucky Relief Commission, and both he and Father Reitzel were on the program of the State Conference of Social Work. In October 1934, Board momber, Mrs. Neville Miller, was chairman of the Louisville Women's Crusade, a part of the National Mobilization for Human needs, and in 1935 served as chairman of a permanent Educational Committee of the Chest to which Mrs. George Zubrod was nomed agency representative. The agency was ropresented in the national organization when Mrs. Halleck was a delegate to the annual meeting of the Family Felfare Association of America in 1931, and both she and Father Reitzel served in that capacity in 1935. The major activity of Board members in the area of legislation was the active endorsement of "anti-loan shark " legislation. Annual Meetings

The annual meetings took on a pattern different from previous periods. All were large luncheon or dinner meetings awry from the building and drew from two to three hundred representatives of the Board, cormittees, general membership and friends of the society. The chief attraction was an address by an outstanding leader in social work from either the public or private field. The Board participated in planning but gradually after 1930 the General Secretary took more and more responsibility for drawing up and carrying out plans. The practice of detailed and interpretive reports of the year's program by the General Secretary and president ended after 1930. For the 1929 and 1931 meetings Board members working in committees took responsibility for 
publicity, arrangements, attendance and invitations and used rolunteers in following up invitations. At the 1929 and 1930 meetings the re was participation by local musicians and a skit by staff members. In the later years many of the activities formerly carried by laymen were taken over by the professional and clerical staff in carrying out arrangements, sometimes with the help of volunteers. Board nembers were responsible for getting attendance by arranging for tables. The white District Conferences attended and in 1936, the chairmen of all the Conferences took responsibility for selection and presentation of the case history in the annual report. The transfer of rosponsibility to the staff for all the details of arrangements no doubt contributed to efficiency but one might question whother many of the activities could not have continued to be carried by laymen and contributed to their sense of participation. The consistent evidence of interest on the part of the membership was indicated by larger attendance than in any previous period. That lessened activity had not reduced the feeling of responsibility on the part of the Board is evident from a letter of Board member Charles A. Gege to the ceneral Secretary in July 1937 in which he stated: "Speakers usually discuss phases of the work conpletely over the heads of many in the audience who make their only contact with the organization at those meotings. I have always felt that a much simpler and more fundamental talk with case histories as illustrations would make a far greater impression on the people at annual meotings."

B. FINANCE AND BUSINESS NANAGEEIENT

The Board continued to play a dominant role in planning and securing the agency's budget, was kept constantly informed of the finan- 
cial situation, and gave much time to the consideration of expenditures. During the first years Miss Esther Paylor was General Secretary, sho sought evaluation of the tentative budget by a few Board members before presenting it to the entire Board. This practice was found so helpful that in later years, after drawing up the budget with the help of the treasurer, an individual conference was held with each Board member prior to Board discussion. In several instances the Board authorized requesting a larger relief budget than that recommended by the General Secretary. The individual members took much responsibility for both questioning and becoming tho roughly informed as to budget needs so that the group as a whole was able to be articulate in presenting the budget to the Chest and to the public. A large proportion of the Board attended the annual budget hearing before the Chest Budget Committee. The Board frequently made suggestions as to changes and mothods of presentation. After a certain appropriation was granted by the Chest, the General Secretary was largely responsible for working out plans for readjusting the budget accordingly, but the Board offered suggestions and always gave final approval to the budget.

In the operation of the agency, the Board retained some responsibilities, referred some to the General Secretary. On Hay 10, 1929, the Board discontinued its earlier policy of directing where agency purchases were made and left this responsibility to the General secretary, but did give advice. The Board continued for a fow yoars to discuss annually the question of agency automobiles but later left this to a special committee acting with the General Secretary. In November 
1929 it authorized the closing of the office in the evenings. Matters of purchasing, or bookkeoping, and of audits were more and more left to the ceneral secretary acting either with the president or treasurer. In relations with the Retail Grocers' Association and with the Louisville Real Estate Board, the president acted with the General Secretary. A spocial committes in 1933 made a study of the whole insurance program of the agency, reported on possible savings and carried out, on authority of the Board. recommendations effecting a reduction in cost of insurance.

The Finance Committeo was responsible for financial organization, the study and execution of recommendations of the auditors, the study of bids for fuel and the investment of funds. No securities were bought or sold without the approval of the Board but details were carried out by the Finance Conmitteo. In later years the treasurer, as chairman of the Finance Committee, assumed many responsibilitios formerly carried by the committee, acted as a financial advisor to the Ceneral Secretary, and was responsible for the Bequest Fund.

The Building Committee was responsible for the operation of the agency's properties, the chairman serving as a personal supervisor of the buildings. Responsibilities for carrying out the details of buying a district office, remodeling programs, securing tenants, and drawing up rental schedules, periodic surveys of the property, borrowing from and repaying to the sinking Fund from the Building Fund and the details of selling property were all delegated by the Board to this committer. In 1931 the Building Committee was responsible for a work 
relief program, surveyed the type of labor needed, established the policy that the wage schedule should be the same as that paid by the public agency, and made use of the $\$ 300.00$ appropriation allowed by the Board to accomplish the remodeling and cleaning of the buildings, the building of walks, otc. This program was carried on for several years.

On April 14, 1931, on the rocommendation of the General secretary, the Board set up a Committee on Endowments to interest persons in the community to make endowments to the agency and to study plans which other societies had carried out. A questionnaire was sent other societies and a logal form was drawn up that might be attached to any publicity the agency was sending out. After some discussion, it was decided not to continue this committee and that if in the future the agency needed to discuss the problem, a special committee would be appointed.

On September 27, 1932, the president appointed Harry Schacter as a committee of one to study the merchandising problems of the agency. Mr. Schacter appointed two merchandising authorities who gave considerable service in advising the agency on estimating needs, buying contracts, and plans.

\section{c. THE FAMILY SERV ICE ORGANIZATION AND THE COMUUNITY CHEST}

It was immodiately apparent in 1929 that the agency budget would be inadequate. On January 24th, a committee of the Board was authorized to meet with the Executive Committee of the Chest and pend- 
ing a decision, the staff was instructed to continue spending as economically as possible but according to needs presented. In coming to this decision, the Board again raised the question as to whether the agency and the Chest should make a joint appeal to the city for emergency funds, whether the public should be informed as to the agency's needs and budget, whother if compelled to live within the budget, the agency should refuse all cases that wald necessitate excess spending, and what the effect of any of these decisions would be on the Chest drive. As a result of the meeting of the president and the General Secretary with the Chest Executive Committee, the agency was authorized to spend an additional $\$ 1,200.00$ befor March 1 st. Although it was clear this would ease the situation only partially, the Board did not accept the recommendation of the Case Policy Comitter that the stafe be allowed to use their own judgment in refusing applications. Similarly, although the county had appropriated $\$ 20,000.00$ to the Chest, the Board decided against again accopting county cases unless the budget was correspondingly increased. Both the Board and the Case Policy Comitter strongly recomended an educational program as to the financial situation and the function of the agency, and left to the staff, responsibility for adjusting to the decreases in budget made by the Chest.

As the unemployment problem increased and the agency was unable with its funds to meet the entire problem, criticism and misunderstanding of both the agency and the chest mounted. In June, 1929, the president, General Secretary, and a representative of the Chest met 
with the editors of "The Courier-Journal" and "The Louisville Times" and adopted the plan that Point of View letters would first be submitted to the agency in order that a reply might be published at the same time as letters of criticism.

The Executive Committee and the Board decided early in this period that the agency had neither the funds nor the authority to provide emergency relief to other Chest case work agencies, and on January 15. 1929, directed the General Secretary to suggest that each such agency present this question to the chest. In this same area of clarification of function, the following month the Board accepted the recommendation of the Case Policy Comittee that the agency provide no clothing upon the request of the School Attendance Department, pending a deoision from a joint committee considering the problem, that no clothing bo provided for patients at Waverley Hills not already clients of the agency, and that no care be assumed for children placed in their own homes but still under the care of Ormsby Village. The Board further decided to discontinue investigations for milk provided by the Public Eealth Nursing Association but in this instance put the emphasis on the inability of the staff to continue because of pressure of work, whereas the committee felt such investigations were not the responsibility of the agency; a similar difference in thinking was evident in the ruling that no further investigations should be made on requests for city coal in cases not al ready known to the agency. It was not possible to carry out the recommendation regarding school clothing although conferences were held with the Board of Education. The agency Board was not 
willing to accept the further recommendation of the Case Policy Committeo that no further relief be given to the single aged and that no further investigations be made for the Home for the Aged, and decided that omergencies should be accepted and that the agency's inability for the time being to make investigations for the Home for the Aged be interpreted to the Board of Safety. Similarly, the Board rejected the recomendation that no more cases of dependency as a result of cancer be accepted.

The Case Policy Committeo continued to fulfill its function of advising and recomending policy as to the case work of the agency. In evaluating the work of this comitter, the ceneral secretary stated on October 14, 1930: "We take up all questions of policy with this committeo, which studies all questions and acts upon them and offers a recommendation to our Executive Committes for formal action.... The chairman is one of the Board members who has a keen knowledge of case work and of staff problems in addition to a knowledge of the administrative side of the work.... We have found it particularly valuable to discuss in detail complicated situations and problems before presenting them to the Board. (It is) invaluable in its ability to help inform and direct the Board.... and as a connecting link between the staff and the Board.... In Board meetings it is the Case Policy Committe日 members who stand up for the interests of staff members." 3

3. Letter from the General Secretary to the Family Welfare Society of Bridgeport, Conn. 
In October 1929 the Case Policy Committee studied inadequacy of relief, standards of relief giving, applications, investigations, and the need of the Board knowing more about actual cases. The committee recomended that the agency continue to limit intake and maintain its standard of work. If it was not possible to carry out this policy with available funds, the committee recommended that additional funds be requested from the chest before excoss spending was allowed. Almost immediately after this decision was made, the agency began to feel the effects of a sharp rise in unemployment, and there was spending in excess of the relief budget and immediately accelerated action by the Board. The Executive Comitter met with the Executive Comitter of the Chest, presented the situation, roquested additional relief funds, and if that was not possible, asked permission to make a special appeal to the public through the press or to ask the city for funds. If neither plan was considered possible, the Chest was informed it would be necessary for the agency to refuse all new intake. As a result of this action, the Chest allowed the agency an additional $\$ 2,000,00$ and requested that no appeal be made either to the city or the general public. Applications increased so rapidly it was apparent by November 19, 1929, that this extra allowance would last only until December 1, 1929. Board President Grover Sales, on authority of the Board, therefore, wrote to William A. Stoll, president of the Chest, as follows: "It is obviously impossible for a private social agency, such as ours, or indeod for the Community Chest, to be expected to meet an economic or industrial dislocation such as that caused by an unemployment situation. It is, of 
course, a responsibility which transcends that of any private social agency and becomes the responsibility of the entire community, its business organizations.... and the City Administration." A subcommittee of the Board held conferences with the Executive Committeo of the Chest, appealed to the Mayor, who indicated unwillingness to ask the City Council for additional funds, then sought the help of the Board of Trade in appealing to the City Finance Committee. These various efforts resulted in an appropriation by the city of $\$ 7,500.00$ to the Chest for the Family Service Organization.

Concurrently with these relations with the Community Chest, the Board was aware that additional funds for relief were of limited help if there was no additional staff. The president participated in many conferences with the staff on methods of meeting the emergency. Since the Chest stipulated that all of its additional allowance was for relief only, the Board authorized the use of special funds for employing extra staff for a short period.

In approving the 1930 budget, the Board adopted a radically different policy in deciding not to request any specific amount for relief but to present the needs to the Chest Budget Committer and to review the inadequacies of previous years. The Board early realized the 1930 budget as set by the Chest would be inadequate and requested an additional $\$ 10,000.00$ be added to the goal, but this request was denied by the Chest.

During this period, the Case Policy Conmittee considered the need for the agency developing a Research Department in order to have 
facts available for interprotation, for understanding of problems and for developing future policy. The committeo drew up a list of studies needed and decided any long time projects should be discussed with the committee before being undertaken. On April 22, 1930, the Board approved the use of $\$ 2,500.00$ from special funds for a research project, and on July 15, 1930, the Case Policy Committee decided the research worker would first study the problem of cancer patients, the blind, the cardiacs, the aged, the chronically ill, and the feobleminded (if the Director of the Psychologieal Clinic thought the last was advisable). The next study outlined was the types of cases being carried by the agency, and it was suggested that the aims and objectives of the society should be woighed against actual practice. In September 1930 the committer accepted the findings of the study of the cost of the chronically ill, blind and feeble-minded in the case load of August 1930 and discussed these with both the Public Health Nursing Association and the Health Council of the Chest.

As 1930 began, in spite of several months' experience with ext reme unemployment, there was still uncertainty as to where responsibility for the care of the unemployed should be placed. On January 2, 1930, Mr. Sales wrote to the president of the Chest outlining the relief situation and requesting the Chest goal be increased so that if the amount were not raised, responsibility could be placed on the community rather than on the agency and the Chest. The Board continued to differ with the Chest as to the setting of goals for campaigns and claimed that when the goal was placed too low, it failed to indi- 
cate the true need, and only served to confuse and antagonize the community when needs could not be met though the adrertised goal was met. The Executive Committee of the Chest failed to increase the goal and refused a request of the agency Executive Committer for a joint meeting. When the needs of the agency were again presented, the Chest Executive Committee ruled that no relief request could be granted that would make the total budget for the year higher than that already planned.

In the emergency, Board members gave almost daily service to the agency. Early in February on the basis of a Case Policy Committeo report, the Executive Committee decided on February 7, 1930, that all service cases (those receiving no relief) should be immediately closed and that unless additional funds were granted, all intake would bo closed after February 12th. Since relief funds for the month would be exhausted by February 20th, the cormittee decided the Chest, the city and the public should be informed of the action. In his letter to the Mayor on that day, Mir. Salos indicated, "We feel it is a community problem.....and without the aid of the City we are powerless." That the eity administration was not ready to take on any such responsibility was indicated by Mayor Harrison's reply on February 8th that the $\$ 7,500.00$ appropriated in December had been to meet a deficit at the end of a fiscal year when the chest could not act, and that if the chest had not provided for the new year, it was no reason for placing the ultimate responsibility upon the treasury of the oity." since additional funds were not immediately granted, the Executive Committee 
ordered that cases where any income was being supplemented be closed and that only the most urgent applications be accepted. While the Chest campaign was in progress, the Executivo Committeo wrote the Chest that the community should be informed of the critical relief situation and of the importance of reaching the goal set. On rebruary 17 th, the president infomed the Board that he had taken responsibility for not cutting off all intake, and requested the General Secretary ask for permission of the Chest for a special campaign for funds for special families. This request was refused, and the agency was requested to live within its budget.

When the Chest campaign failed to reach its goal, the Board studied the cuts necessary, examined the constitution of the Chest and determined it was legitimate for the agency to conduct a campaign among non-contributors to the chest for an amount necessary to make good the allowed budget for the year, provided that such a campaign was not conducted one month before or one month after the regular campaign. The Board, therefore, notified the chest that it would conduct such a campaign, left to the General secretary decision as to the linitation of case work, and disallowed some of the staff reduction planned. The General Secretary, after consultation with the staff decided to cut off after March 15th all single aged, able-bodied couples, service cases, (the staff was reluctant to cut off this group), non-residents refusing to return to place of residence, adult families, and ablebodied men with one or two children. The committee to plan the special campaign was active in working with representatives of the press, but 
plans were dropped when it was impossible to work out plans that would protect the clients from publicity and outside investigation.

In April 1930 the Board voted to draw from legacy and $g$ ift funds $\$ 5,000.00$ for relief purposes, and $\$ 2,500.00$ for continuing the research project, with the understanding that the Case Policy Committeo would continue to advise the research worker and that the Board might continue this project at any time (the Executive Comittee later authorized the borrowing of funds to cover this amount as it was not. deemed wise to sell any securities at that time). The Executive Committee decided the $\$ 5,000.00$ should be used within a fow months rather than spread this over the balance of the year. The following month, the president of the Board, with the consent of the Chest, wrote an open letter to the press about the situation confronting the agency. This letter resulted in contributions of over $\$ 5,000,00$ and the egency was able to operate through the sumer on this and the money drawn. from the endowment fund.

When Miss Taylor became acting general secretary in the sumer of 1930, in order to ease tension, plans for a shift in responsibility for relationships with the Community chest were immediately made. It was decided that in every instance possible the working out of details of policy would be carried on between the two executires, or between the ceneral secretary and the president of the Chest board. From that time on, 211 correspondence, even that addressed by the chest to the president of the Family Service Organization Board, was handled by the General Secretary. In later years when the areas of difference had 
diminished the practice had become habitual so that the re was no return to lay activity in this area.

In September 1930 the Case Policy Committee, in conjunction with the Ceneral Secretary and the supervisory staff, drew up a statement of agency function which was significant as the first formal statement of limitation of intake. This statement was attached to the next budget request to the Community Chest and was referred to in interpretation to the city administration:

We believe that we, as a family agency, should deal exclusively with a family and by' familyt we mean a man, a woman and their dependent children; a man and a pregnant woman. We shall, however, accept the responsibility of returning to their legal residence a family who has been here over one week. We shall also upon rare occasions assume responsibility for investigating the legal residence of and returning a single transient not previously known to other agencies if sickness is involved.

"The increasing complexity of social work has forced organizations throughout the country to a realization that no family agency can expect to care for all the persons in the commity who need case work treatment. The Family service Organization, too, has found that some limitation of function is inevitable. Hence we cannot accept for care: couples, either young or aged; the single man or single woman; or children without parents; however, we recognize that they do need case work treatment and suggest that some provision be made.

"Families for whom we accept responsibility should be considered in terms of what treatment we can offer them. Our aim is to effect adjustments in personality and relationships within the individual family or between the family and its environment." 4

4. Statement of Function, September 19, 1930. 
With the relief funds fran special sources exhausted, the agency notified the Chest on September 15, 1930, that intake would have to be closed on October lst unless additional funds were appropriated. The Chest agreod to allow $\$ 2,000,00$ additional for October if intake would not be closed, but the Board accepted this offer only on the condition that no responsibility be assumed after October for any families so accepted. It was not necessary to carry out this plan, however, as the agency received another special gift in october of $\$ 2,000.00$ and the city appropriated $\$ 7,000.00$ for relief. The Case Policy Committee determined what classes of cases should be accepted with this appropriation and worked out plans with the Mayor for using the entire sum during November. The opening of the Unemployment Relief Bureau in November, 1930, relieved somewhat the pres- 、 sure on the agency. From that time, the Board, sometines jointly with the chest, turned much of its attention to the development of the public relief program.

Throughout all this period, the Publicity Committee, under the chairmanship of Brainard Platt, did much to interpret the agency's work and the need for public resources.

The policies of the Board came in conflict with the Community Chest Board regarding salaries late in 1931. A year previous the Board had not followed the suggestion of the Chest that staff racations be reduced. On October 16,1931 , at a meoting of the presidents of all Chest agencies a resolution, adopted by the Executive Cormittee of the chest, was presented. It called for each agency 
making salary outs according to a schedule set up on the basis of various salary groupings. Although the president of the Family Service Organization voiced opposition, a majority of the group approved the action without consulting their agencies. At a Board meoting on October 20th there was some difference of opinion, but the matter was referred to the Case Policy Committee. That group secured information from thirty other family societies, met with a representative of the staff, and on October 26 th recommended that no cuts be made in salaries. This conclusion was based on the fact that salaries in most other family agencies studied were higher, that "the Family Service Organization had established a national reputation for the efficient and economic basis on which the relief work was conducted last winter," that the load of work was heavier than in normal times, and that "the organization has a moral obligation to its employees to fulfill contracts where they have been definitely entered into." The following day the Board ordered the resolution sent to the Central Council of the Chest and instructed the president to vote nogatively to any type of salary reduction. Mr. Brainard Platt represented the agency at the Chest Council meeting on October 28th and stated the Board believed that the agency, although an integral part of the Chest, was an independent body. The agency's resolution was defeated. The Board did not accept this decision as binding and on November 17th informed the Executive Committee of the Chest that since the public had been notified that all social workers' salaries were to be cut, the Board felt ethically bound to inform the public that the agency 
considered the action of the Central Council only a recomendation and that the cut in the total budget would not necessarily be made on salaries. This action resulted in a resolution by the Executive Committer and Central Council of the Chest on November 30th that "the agencies should not reduce their staffs or their efficiency in meeting the salary reduction, but it was the consensus of opinion that, if the total amount of the cut were met in salaries, the agencies had the right to apply the reduction within the discretion of their Boards."

In 1938, the Board, while endorsing several of the measures acted upon by the national board relating to Federal programs, postponed action on favoring the inclusion of employees of social agencies under the social security Act. It was suggested that a committee be appointed to study the question and ascertain what plans the chest had for a retirement program. Such a committee was not appointed as a large proportion of the Board membership was opposed to inclusion of social agency staffs in the Society Security Act.

Although many inter-agency relationships were delegated to the professional staff, the Board continued periodically to foster cooperation and to define function. In 1932 the Board authorized the agency to give assistance to the League of Women Voters in their study of Jefferson County Welfare Department. Later in 1932 Board member Dr. H. H. Hagan was active in working out plans with the State and City Health Departments for leutic treatments for agency clients. In 1935 President Grover Sales cooperated with the Legal Aid Society 
in working out arrangements between the Legal Aid Society and realty companies regarding evictions. In Norember, 1935 a special committer of the Board met with city authorities to bring to their attention the need for facilities for dental care for Negroes.

D. THE FANILY SERVICE ORGANIZATION AND THE CITY DEPARTMENT OF WELFARE As has already been indicated, efforts to secure city appropriations for relief were at first directed toward the public subsidies for the private agency and were coincident with the inability of the Chest to meet the agency's increasing needs. Decisions to out off various categories of cases were at first related only to the agency's inability to meet all needs rather than to conviction that certain groups were the responsibility of the public. The necessity for the development of a public department supported by tax funds very slowly gained the approval of citizens and after the establishment of the Department of Welfare, clarification as to division of responsibility between public and private agencies developed slowly.

On the basis of research studies within the agency, the Case Policy Committer in December 1930 decided that all dependent aged should be referred to the Department of Public Welfare for investigation. It recomended further that if, after investigation, the public department found that the Home for the Aged was not the proper solution and that there were not sufficient resources within the family, the situation should be discussed with an advisory comitter, such cormitter to decide what action should be taken. It was believed that such an advisory committee, to be composed largely of socially minded 
representatives of the community, would serve the double purpose of an advisory body and an educative force that would bo helpful in establishing the city's responsibility for the aged. Information is lacking as to whether such a committeo over functioned.

Thraughout 1929 and 1930 interest in an employment bureau continued, as the tentative plan for establishment of a bureau had not materialized. Nrs. Halleck, in January 1929, secured advice from the national organization as to the advisability of the agency participating in such a program and held conferences with the Director of the United States Employment Service. In Vay a resolution from the Portland District Committeo stimulated the Board to initiate action again. The Executire Committee of the Chest on June 4th rejected the request of the Board that the Chest supplement the budget of the public employment bureau as "the comittee does not consider this a proper function of the Community Chest. The committee feels that if the froe public employment bureau is to be enlarged, it should be from City, State and Federal funds and not from the Chest." lir. Sales then requested that the Chest stimulate action toward the establishment of an employment bureau but was informed the Chest did not intend to accopt this responsibility. Various civic organizations, in addition to the special comittee of the Family Service Organization Board, continued to discuss the problem and to urge the chest to interpret the question whether an employment bureau was a legitimate function of the Chest since several agencies continued to do limited employment placing. 
In November 1929 the Executive Cormittee authorized the setting up of a special Employment Committee to attempt to work out better arrangements with the United States Employment Service and private employment agencies, recognizing that the opinion of the Chest would have to be considered if a separate employment bureau was considered. This comittee outlined its objectives as threo-folds to discorer if exceptional unemployment exists; to obtain jobs, if possible, through public works or employment agencies; and to recomend a definite program of action. The committee secured the service, as a volunteer, of Miss Harriet Anderson, former executive, to clear on employment possibilities for the agency, to make contacts with employment exchanges, and to compile information. Frequent meetings were held to study the findings compiled by Miss Anderson and to formulate policies surrounding the experiment of using agency funds to send a selected group of clients to commercial employment agencies. Reports were made to the Mayor and the Director who were urged to derelop public work possibilitios. A letter of interpretation of the unemployment situations and the work of the United States Employment Service was sent to all ministers of the city. On December 17, 1929, the comittee in a report to the Board, approved action of the agency and of the chest to secure funds from the city to meet emergency neods for relief, and recommended prompt establishment of an adequate public enployment bureau by city and federal authorities. It stated further: "A general condition of unemployment is a social breakdown..... A city is the smallest unit that can adequately handle a situation of social 
breakdown such as wide spread unemployment..... The Family Service Organization is designed to build up self-maintenance in individuals and families. It can do this only when social and economic facilities are present in a community." On authority of the Board, the committee continued to meet with the Director of Welfare, studied plans of other cities, and to urge Chest action. After the establishment of the Unemployment Relief Bureau, the comnittee gradually ceased to function.

Although the ostablishment of the Unemployment Relief Bureau relieved the burden of unemployment relief felt by the agency, it operated a work relief program only during the summer in its first years, and there were many unemployed not eligible or not able to take work provided. Relationships with the Department of Welfare were handled largely by the ceneral Secretary. In January 1931 arrangements were made for re-imbursement out of Departinent of Welfare funds of money spent for transportation for clients out of the city. (Such funds had formerly been drawn from the general funds of the city). The Board endorsed the plan arranged for making a small amount of agency funds available for clients of the Department of Welfare not able to manage on the weekly work relief wages since "the Mayor does not wish the Department to become in any sense a relief agency."

As the 1931 budget provided by the Chest did not meet relief needs, the Board authorized continued excess spending until some plan could be worked out, and on February 27, 1931, two Board members 
and the General Secretary met with the Mayor and the Director of Welfare, and vice-president and executive of the Chest. It was decided that the Family Service Organization would prorate the entire balance of relief for the year over the period to september 1st, and the vayor promised to attempt to get city assistance at that time. (The city's fiscal year began in September and city pledges of support often could not be met until the following fiscal year.) Although the Chest Executive Committer agreed to maintain a skeleton staff at the agency if the city made no appropriation in September, the Chest policy was expressed by the Vice President Alexander Heyburn in a letter to President Grover Sales on Narch 2nd as follows: ".... it is going to be absolutely necessary for our relief work to be done on a much more moderate scale from now on, regardless of conditions." The carrying out of the plan was delegated by the Board to the Case Policy Comittee and in doing so the comittee over-ruled the advice of the ceneral Secretary that the administrative and service budget be prorated over seven instead of six months in order to protect the staff, and guaranteed that the agency would be protected after September lst by some means. When another request for permission to make a special appeal for funds was made in Narch by the Executive Comitter meoting with the Executive Comittee of the Chest, the request was granted on condition it met with the approval of the liayor. A meeting of the two executive comittees with the Mayor and the County Comissioners resulted in a county appropriation of $\$ 50,000.00$ and the plan for a special appeal was dropped. 
On July 3, 1931, the Executive and Case Policy Committees disapproved of continuing indefinitely the policy of accepting public funds and meeting emergency situations as they arose. They approved a plan "at once for assuming only the case work which is the responsibility of the Family Service Organization, but temporarily to carry unemployment relief ceses for the city on the present basis with the understanding that this unemployment relief is a public responsibility and is to be taken over by the city at a definitely agreed date." The Mayor indicated the city would assume responsibility for the unemployment load and would appropriate funds to the private agency for its own load to January, 1932. The city also appropriated $\$ 5,000.00$ for salaries of private agency workers. When the Mayor on January 26, 1932, indicated the public agency would be closed when funds were exhausted as he was "absolutely opposed to having his department give relief," the Board authorized a separate Unemployment District be established "to facilitate separate financing, and to keep the noed of the city taking over this rosponsibility uppermost."

Because of the heavy load of work undertaken by the new public agency, many criticisms arose, and the private agency felt much responsibility as the community was confused as to division of function and looked to the private agency when there was dissatisfaction with the public agency. On February 17, 1933, the Case Policy Committee declared the agency could not refuse to investigate a serlous case if the Bureau did not accopt responsibility.

With the appropriation of federal funds and the functioning of the Kentucky Relief Commission, the agency was faced with the 
pressure from that group to dictate policies of the private agency since it was expending federal funds. On April 17, 1933, the Board authorized the agency not to accept any order from the state agency to give relief in any case. Difficulties with the city agency continued as that agency felt similar pressure and also had inadequate staff. The private agency continued to feel a responsibility both to the community and to the public agency. A meeting of the president and General Secretary with the Mayor on May 16, 1933, brought out the difference in philosophy between the public and private agencies as to whether the public agency was a social work department with work relief given on that basis, or merely an employment bureau. The hesitancy of the private agency to give over entirely its former responsibilities to the public agency, the questioning of the ability of public agencies to give service, so prevalent in private agencies, and the feeling of responsibility to the clients was indicated by the offer of the Family Service Organization of a demonstration of investigation on a group of Bureau families, and a questioning as to whether the agency should not accept some of the active Bureau families to prevent development of problems other than unemployment if no service was available at the public agency. The foderal ruling, effective in August 1933, that federal funds could not be expended through private agencies, resulted in many emergency arrangements in which the Board was active. The Board authorized that its officers had authority to act in case of omergencies. Meetings of the president and General secretary with 
the Mayor and Director of Welfare urging the employment of more staff for the public agency resulted in the liayor's agreement to reimburse the agency for paying the salaries of ten additional workers at the Bursau for two months. In order to make possible the agency's continued receipt of federal funds the Board authorized the temporary designation of the agency as "Family Service Organization Home Relief Section of the Municipal Relief Bureau" until November 7, 1933. With federal funds cut off, the chest secured an emergency appropriation of $\$ 5,000,00$ from the county for the remainder of November, and after a meeting with the new Mayor, the president and Coneral Secretary secured his approval of the city appropriating funds for the agency's relief noods during December. This period of rapid development of public relief raised many questions as to the future of the private agency. On November 1, 1933, the Board discussed merging with the public agency, but decided it was wise to continue independently, even if necessarily on a much smaller scale, as "the private agency is necessary if for no other reason than to take care of the many families which could not be taken care of by the public agency bocause of their rules and regulations." The following month the president participated in working out plans for loaning three members of the Family Service Organization staff to the public agency for supervisory positions.

President Sales was appointed by the Director of Welfare as a member of the Advisory Committee of the Department of Welfare and reported to the Board, on February 20, 1934, some reversal in thinking 
as a result of discussions of the relation between private and public agencies. It was agreed that instead of the public agency taking over all cases of need and stopping public subsidy of the private agency, appropriations should be made to the private agency until the public agency was ready to take on the larger responsibility. The Board, therefore, recommended that consideration be used before any more of the agency's case load be turned over to the public department. The Board enunciated its conviotion that it was the function of the private agency to set standards and protect the public department from political interference, to act as a training center for social workers, and to bring in good workers from outside the city when necessary.

The loan of workers from the private to the public agency further increased the close working relationship between the two agencies and the protective attitude of the private agency toward the public. There was increasing evidence of the judgment of the Director of Welfare that public subsidy to the private agency should be discontimued as soon as possible, and the first largo group of families, other than the unemployed, was transferred from the private to the public agency early in 1935. This procedure was worked out by two members of the Board meoting with the General Secretary, representatives of the Chest, and the Director of Welfare. As the city subsidy to the Chest was gradually decreased, the Board continued to be active in urging more adequate city appropriations to the public agency. In January 1937 when unemployment again increased and the city provided no funds for relief or investigation of employables 
through the Municipal Bureau, the private agency felt the effect in increased applications. On January 19, 1937, the Board considered whether the agency should make any exceptions and accept any unemployment cases because of mounting criticism and its effect on the chest drive. The Board decided against making any exceptions and that a clear explanation of the situation be made to the public with the interpretation that unemployment was a publio responsibility. The Case Policy Committer and Board were also active in making known to the Governor and the Commissioner of Welfare their advocacy of trained personnel for the State Department of Welfare.

As the public department and its program became stabilized there was less Board activity with that department. At the close of this period, however, the change of eity administration with its imediate change in attitude toward the function of the public agency and its relation to the private agency again called for lay participation in attempting to work out the subsequent conflicts which were of major importance in the following period.

Prior to transfer of major relief responsibility to the public agency, a special committer of the Board was actire from 1933 until late in 1935 in attempting to work out a back-to-the-farm program for agency clients. This Farm Committee was composed of representatives of the Board, the Board of Trade, the University of Kentucky, the County Agriculture Agent, and several banks responsible for farm properties. Many plans were studied but the plan was dropped in 1935. Nost of the families for whom the plan was contemplated had been transferred to the public agency. 


\section{E. VOLUNTEERS}

Recruiting of volunteers under way in 1929 through the Recreation Council of the Community Chest. The Recreation Council, and later the Council of Social Agencies, continued this service and to give initial education to volumteers. This source supplied high school volunteers in 1929 and thereafter. In 1931 the agency had a Committee on Volunteers, which the General Secretary described as follows: "It is made up of representatives of various groups, such as the Junior League, men and women's clubs, church groups, the colored group, and the Jewish group ... (each ) .. takes the responsibility of carrying back to his own group the request for volunteer service and also takes the responsibility of weeding out the undesirable prospects." Church groups, individuals, and service organizations also served as agents to fill volunteer needs in the early depression years when the agency was overwhelmed with unemployment relief loads, inadequate staff and budget. Stenographic Service

Stenographic service was given by high school students, Junior League members, and other interested women. In 1929 throe clerical volunteers were listed, but by 1934 thirty-four served regularly. Records of time given are adequate only for 1936-1939, but many gave several hours every weok. After 1934 as the unemployment load was shifted to the public agency the need for volunteer stenographers decreased. Motor Service

In December, 1929 the cheirman of the committee for motor service appealed for volunteers and in 1930 at least twenty-four women drove workers on field visits or sent their cars, increasing the amount of work done by the staff and helping the agency keep 
within its field expense budget during these two heaviest years. In 1932 there were motor volunteers, but records indicate they were not used regularly, that they did not prove reliable, and that they only served a few times. Motor service as a regular volunteer service proved expensive and a burden to the volunteers; it was difficult to sustain interest over a long period, and the additional factor of legal responsibility may have been considered a hazard by the rolunteer. The motorists of the years 1934-1938 were few and only one or two gave regular time for an extended period. As younger staff members were employed who were able to drive the agency carB, this volunteer service was not needed as it had been in the earlier years. Case Work Service

Case work service by volunteors reflected most directly perhaps the change in the work and function of the agency. From 1929 to 1934, volunteers were chosen with care to help with routine investigations, to do some visiting, to assist in the application department in clerical and interviowing capacities. In a letter on April 1, 1931, the General Secretary describes the use of this type of volunteer as follows: "...ea few volunteers who had knowledge or contact with social agencies in the past assisted in the application department. They registered and eleared the applications and on some occasions took applications." The church visitor is referred to in this letter as "....used in the Unemployment Emergency Department, where we were working with only unemployment families and where we were not attempting to do a case work job but only to investigate before relief was 
given....to verify work records, to follow the regular visitor's initial investigation by making calls to take grocery orders and to check upon the present situation." Some other case work volunteers gave full time service on an apprentice basis that led occasionally to their becoming staff members. University students often gave full time case work service on a volunteer basis during vacation periods. With the transfer of relief function and the emphasis on service after 1933 the use of volunteers for case work service was limited. Considered as "case work volunteers" in 1934-1938 were Junior League Members, who were carefully supervised, who answered some types of letters of inquiry or helped with camp preparations,otc. In 1937 and 1938 two Negro workers gave full or part time volunteer service and were supervised on a student training basis. However, the trend in the agency by 1937 was distinctly away from volunteer visiting in fomilies.

Other Church Groups

Nume rous church groups served the agency in many ways but little of their activity was adequately recorded. Sewing for the agency was done by such groups. Through interest in sewing for the agency, one group from several churches in the Highlands undertook a neighborhood teaching project in Highland Park with women and girls from agency families. This became a cooperative enterprise not limited to agency families but was still guided by a staff worker. Woney made from the sale of articles was used to buy material for the members to use. This club eventually became a self-supervising 
body but continued to do occasional sewing for the agency. Other church groups furnished volunteer visitors. The Crescent Hill Social Service Conmittee continued to be of assistance to the agency in assuming full responsibility for certain families, under the supervision of a staff member.

Special Projects

Special projects were often largely dependent on volunteer service under the guidance of professional staff. In the summer of 1932 in an effort to supplement the relief resources of the agency a Conservation League was organized to sponsor gardening and canning. A large volunteer committeo under the active leadership of a small group of club women stimulated client gardening, collected jars for canning, and organized a Conservation Sunday in Louisville churches that resulted in a donation of over 50,000 cans of food.

In December 1934 a group of women Board members sponsored a committee that secured from hotels, institutions and clubs contributions of household equipment for the agency's clients. As a result of this activity, the Portland Community Committee becene interested in stimulating various volunteer groups to give special needed items to families as part of a constructive Christmas giving program. •

The awareness of the need for such items that could not be supplied from limited relief budgets coupled with the need for training and employment for men, wonen and older adolescents ineligible for referral to the public agency led the Board to decide in 1935 to set up a work shop and sewing room. Board members gave wuch time 
to publicity, to appoals for material, and to search for suitable quarters. When the project was ready for operation, the Crescent Hill Women's Club accepted sponsorship of the sewing room, and during the winter and spring of 1935-1936 nine women, working in groups of three, gave three days' service weekly in teaching and supervising sewing. They were active al so in securing much material for repair by the men and boys in the work shop. Later when a staff member was placed in charge of the project the club women continued to give some volunteer service to her.

All of these services by volunteers were of valuable financial help to the agency during a critical period. Volunteers came to foel a real identity with the agency and because of their awareness of the agency's limited budget, they often gave or secured specjal gifts to the agency. They proved an active medium for interpretation of the agency's work, needs and problems and many continued an active interest in the agency after service was concluded.

\section{F. PROFESSIONAL EDUCATION}

On two occasions special committees were active in assisting the development of facilities for training at the University of Louisvillo. In January.1936, a conmittee studied the need for a graduate school, and the Board in March carried out the committee's recommendation that a letter be sent to the University indicating the Board's interest in the development of such a school. In December, 1936, the Board went on record as approving the development of the school into a two year graduate school and the agency offering fellowships in the 
form of part time salary to graduate students. On June 8, 1937, when the Board receired a request from the Kentucky Chapter of the American Association of Social Workers that each agency Board consider offering fellowships at the newly approved Graduate Division of Social Administration on a two year basis, a committee was appointed to study the question of scholarships again in relation to the earlier approved plan of part time salary. The latter plan was felt to be wiser and the plan as outlined by this committeo was put into operation in January, 1937.

\section{SOMNARY}

The heavy responsibilities carried by the agency in this depression period resulted in lay activity being concentrated in fewer areas than in preceding poriods. The many emergencios resulted in a unity of action that played a vital part not only in sustaining and maintaining the agency but also in influencing the development of public relief. The close contact of the Board with the staff did much to maintain morale and stimulate confidence in the staff's ability to carry some responsibilities formerly assumed by the Board. Volunteer services again assumed the proportions found in the early periods of the agency's history and not only made possible an extension of services but also formed a vital link between the agency and the cormunity.

The rapid increase in need in this period served to clarify for the layman the agency's inability to meet the entire problem and brought the conviction, lacking in earlier periods, that public relief 
was not only a necessity but also should be expended through a public department. The confidence in the agency, doubts as to the adequacy of the public programs and the conviction of the private agency's responsibility to the community resulted in periodic questioning as to the wisdom of too rapid transfer of responsibility. The transfer of the major relief responsibility, while raising questions as to the future of the private agency, served to focus attention again on defining private agency function. Although beginning efforts had been made to limit function in the precoding period, the statement of function issued in 1930 was significant as the first formal statement of such limitation. Studies of the extent of unemployment and the efforts made to secure improved public employment services, in both of which the Board participated, together with interpretation by the staff of the extent of need gradually brought about a change in philosophy as to the extent and duration of unemployment and the public's responsibility for meeting it. 
CHAPTER VI

THE FAMILY SERVICE ORGANIZATION

$1938-1941$ 


\section{THE FAMILY SERVICE ORGANIZATION ${ }^{1}$ 1938-1941}

Although this period covers too brief a span to reveal a rango of developments comparable to earlier periods, it brought to culmination certain trends indioated in earlier chapters.

Although nationally, publio services continued to be modified and expanded, state jurisdiotions lacked uniformity in availing themselves of these services. Social security programs developed slowly in Kentucky. Old Age Assistanoe grants were meager and neither Aid to the Blind nor Aid to Dependent Children programs beoame operative. There oontinued to be no state assistance to $100 a l$ communities for general relief.

In the private family field, agenoies throughout the country placed stress on the preventive aspoots of treatment, recognized the treatment possibilities in early deteoted problems and further clarified the division of responsibility between themselves and other agenoies. There was further experimentation in merging of agencies and increased attention to interpretation of the role of the private family agenoy. Emphasis was placed on continued examination of the need of relief in private agencies and clarification of the conoept of

1. Material for this chapter, except where indicated, has been taken from reports of the Board and its committees, annual reports, correspondenoe, publicity and the Preliminary Report of the Family Welfare Comitteo of the Community Chest Survey of 1939. This report was acoepted by the Board although certain differences exist between it and the final report released by the Community Chest. 
relief as part of the servioe program available to families economically independent as well as those economically dependent. There wes continued recognition of the relation of the family field to social ohange. "A definite and planned part of the family welfare program should be stimulation of publio understanding and oorreotion of community conditions which blook the oase worker as well as the client but which are beyond individual control." ${ }^{2}$

Publio relief developed slowly in Louisville and the publio agency was handioapped by inadequate funds and staff turnover. Civic and professional groups gave much attention to interpretation of the need for more adequate oity appropriations to oare for dependent groups and for improvement of personnel. Prior to this period, division of responsibility between public and private services lagged behind developments in many other alties. Changes in city administration late in 1937 brought almost immediate drastio reduction in public subsidy to Community Chest agencies and necessitated immediate clarifioation of responsibilities. Plans were made for the transfor of familios classified as dependent because of non-support or incapacitation from the Family Service Organization to the Municipal Bureau of Social Service. The reduoed relief and service budget of the private agency allowed for care of a much smaller number of relief families monthly and required some reduction in staff.

2. Statement from the Family Welfare Association of America quoted in the Preliminary Report of the Family Welfare Committes of the Community Chest Survey to the Board. 
Further olarification of function was brought about by the 1938-39 Community Chest Survey of the programs of all Chest agencies. This survey to which the boards of the agencies agreed was recommended as "essential to the future support of private agencies that a definite analysis be made to determine what functions of the community welfare are obligations of public or governmental authorities and what functions are the obligations of the private agenoies. $n^{3}$

\section{A. THE COMUNITY CHEST SURVEY}

The Survey oomittee in its findings set forth clearly the effeot of inadequate public programs on private egencies: "It will take the concerted effort and interest of all members of boards of direotors of all Chest agenoies to make these facts sufficiently well knownthat the city will feel obligated to allocate funds for adequate care for dependents and their families. Chest agenoies and their constituent boards have a responsibility to assist actively in the oreation of public opinion so that adequate funds shall be made available for the dependency group with adequate standards of relief so as not to impair the health and morale of those in need. Breakdown of family Iife due to inadequate administration of public relief is bound to inorease the burden of responsibility of the privately supported family agencies." ${ }^{4}$

3. Lotter from J. E. Hardy, president of the community Chest, May 9, 1938.

4. Preliminary Report to the Board, op. cit. 
Many of the specific recomendations to the Family Service Organization influenced future Board and committee responsibilities. It was deemed important that immediate steps be taken to acquaint other agencies more thoroughly with the present function of the agency. "This responsibility should be assumed by nembers of the Board of $\checkmark$ Directors as well as the executive." New quarters for the agency in a section of the city more accessible to clients were thought to be important. Constitution and By-Laws, case work and personnel policies and standards had not been revised to conform to newer function. "The preparation and use of such material will serve as an excellent way for the Board to participate in the development of the agency program and as a means of producing material which can be used in further interpreting the agency's fluction in the community. Board comittees are natural channels for such interpretation." An increase in the financial assistance item of the budget was generally recommended and the extension of services to a cross section of the population, to specific groups and to other agencies.

It is not within the scope of this study to discuss in detail 5 the current function of the Family Service Organization. It may, however, be sumnarized as follows: "to give advice and counsel on family

5. Current program and policies have been examined in greater detail in a study by Marian E. Prinz entitled "A Study of the Family Service Organization, Louisville, Kentucky, in Reference to Intake 1884-1940." University of Louisville, 1941.

6. Preliminary Report to the Board, op. cit. 
problems to any family in Louisville who seoks such help... In addition to the family service rendered, it also extends financial aid in cortain situations. The relief funds are used for those who are not eligible for public funds acoording to the present policy set up by the public agencies." Services were considered to fall into two general classes, those given directly to individual families, and consultation services to individuals and other agenoies.

\section{B. CURRENT ORGANIZATION AND ACTIVITY}

After the sudden transfer of all major relief responsibility to the public agency early in 1938, both Board and staff moved slowly in testing out new practice and policy. There was little previous experience to serve as a guide. Experimentation was necessary to determine in what areas the limited relief funds could best be used and to what agencies and groups of individuals services might be extended. Constitutional Revisions

The Constitution and By-Laws were revised by the Board on May 16, 1939 on the recommendation of a committee, composed of Board and staff members, that made a thorough study of similar material from many other family agencies.

Membership was provided for as follows: "(a) any person who contributes $\$ 5.00$ annually to the Community Chest or to the general funds or to the trust funds of the organization, and (b) Any persons, who, having expressed their interest in the organization, their approval of its ideals and methods and their desire to be sympathetically 
associated with it, may be elected to membership by the Board of Directors, as may any outstanding citizen who will be interested in interpreting the work of the organization in the community." ${ }^{7}$

Management of the organization was vested in the Board of Directors of twenty-seven members elected by the membership of the agency at the annual meeting. The Board was divided into three groups of nine directors, each to hold office for a term of three years and eligible for re-election. Responsibility for nominations for Board membership was delegated to the Membership Committee but provision was also made for nominations by the members of the organization, provided such nominations were filed in writing with the General Secretary five days before the annual meeting. The Board was given power to fill vacancies occurring in its own body, such election to be for the unexpired portion of the term of office of the former director. Provision was made for regular monthly meetings of the Board, except in June and July, in addition to special meetings called by the president or three members of the Board. Officers of the Board, to be elected by the directors at the first meeting following the annual me日ting, were designated as president, first and second vioe-presidents, and treasurer. Authority for carrying on the work of the organization was delegated by the Board to standing and special committees, subject to the

7. Amended Articles of Incorporation of the Family Service Organization, Louisvillo, Ky•, May 16, 1939, Sootion I.

8. By-Laws, Amended May 1939, Articlo II, Sections 1,2,3,4; Article IV, Section 1. 
control of the Board. The function of the five standing committers was outlined as follows:

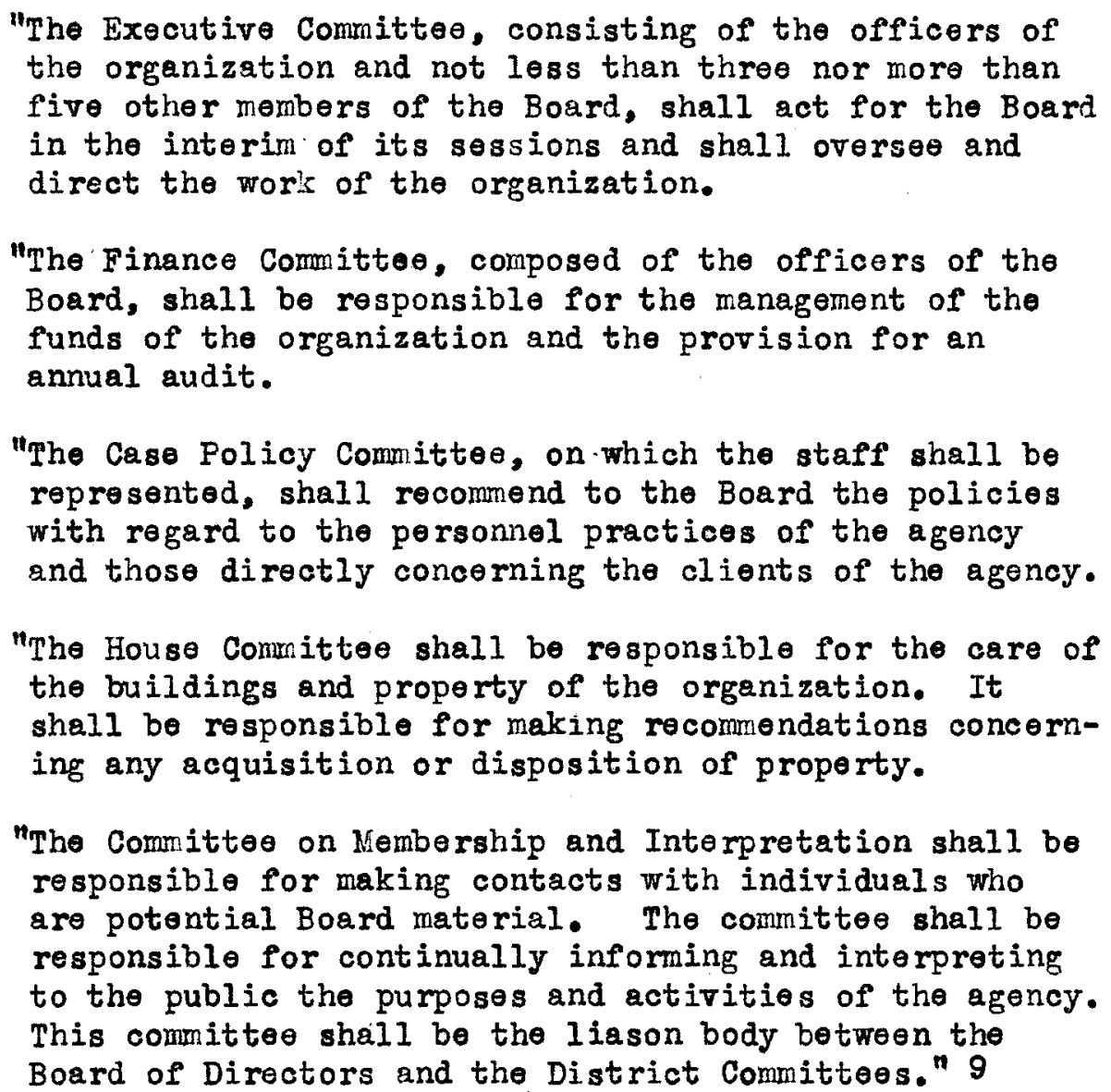

\section{The Borrd}

The Board was kept fully informed by the General Secretary of the problems incident to the transfer of the many cases to the public agency in 1938. Case material was again presented as illustrative of the developing service program and experimentation with the uses of relief. The General secretary frequently turned to

9. By-Laws, Article V. Committees. 
individual Board members for counsel during this difficult period and secured the approval of the entire Board before changes in intake policies were effected.

Even before the chest Surrey the Board was cognizant that the changed function of the agency implied more active interpretation to the public. At the request of the Board, President Dietzman, after consultation with the president of the Community Chest, in February, 1938 issued a statement, through the Point of View columns, of the changes in agency function and relationship with the public agency. The chairman of the Interpretation Committee at about the same time prepared an interpretive bulletin that was distributed to the membership and to other agencies.

As a result of difficultios with the Director of Welfare as to the method of transfer of cases to the public agency, the Board on March 15, 1938 made a request of the Community Chest that in the future the Board be represented at any conferences between the Chest and city officials on matters involving the agency.

Throughout this period the Board in general continued to differ with the policy of the chest in the setting of campaign goals. Although there was recognition of both points of view, i. $\theta$. , the setting of attainable goals versus goals representative of ageney neods, the Board believed it was the responsibility of the chest to interpret the fact that a goal reached did not imply the meeting of all conmunity needs. In differences over salary schedules, the Board contimued to maintain its right to make adjustments within the 
approved budget. In 1940 it also declined the request of the chest for a reduction in dues to the national organization. In the 1941 approved budget the Chest significantly made no recommendation regarding the apportionment of decreases.

When the Chest Comittee on Personnel, established at the suggestion of the Survey, reported in 1940 its recommendations on minimum and maximum vacation and sick leave policy, it made clear the recommendations were not binding on member agencies. It seemed significant that the maximum standard conformed to current practice of the Family Service Organization. The Chest also carried out Survey recomnendations for revision of its constitution. When revisions were voted on by the Central Council of the Chest in 1940, the Board's opposition to remoral of the statement "There shall be no interference with internal management and with traditions of any member agency" was upheld by the Council. Similarly, the Board objected to the provision in the proposed constitution that would have required agencies to report direct gifts to the agency applicable to current needs which might then be deducted from the amount allowed by the Chest to the agency. The Board agreed to report such gifts but was sustained by the council in its proposal that such funds not be deducted from the budget of any agency if they were designated by the donor for a special purpose. In February, 1940, the Board acted upon recommendations of two of the District Conferences and the Conmittee on Membership and Interpretation in notifying the Chest that the agency was opposed to the use of pictures of its clients in Chest publicity. 
A change in city administration not only resulted in the drastic reduction of public subsidy to the Community chest but al so in failure to provide proportionate increases in the budget of the public agency. The Board maintained its concern for adequate standards of relief and porsonnel in the public agency and its awareness of the relation of inadequacies to the work of the private agencies. A committee of the Board, in two meetings with the Mayor, the Director of Welfare and representatives of the Advisory Committee of the Department of Welfare, attempted to bring about improvement. Although these meetings failed of their purpose, they formed a part of gradual community action that later brought about improvements in the public agency.

The only other recorded incident of inter-agency relationship in which the Board participated was that involving the agency's responsibility for clothing for needy school children not active with any agency. In 1938 when the budget for that item was inadequate to meet the neod, the Board decided the fund should be prorated throughout the yoar and that children in families of wage earners employed through the Works Progress Administration were the responsibility of the Department of Welfare. When these funds were cut off as part of the public subsidy an emergency resulted, because funds were not made available by the city to the public agency for carrying on this work. In the emergency, the Board approved the agenoy continuing for a few months to provide such school clothing out of funds donated by a local industry. After 1938 the agency did not egain assume this responsibility. 
In this period the Board perticipated little in questions of personnel except to set up general policies. It held that responsibility for employing and dismissing workers rested with the feneral Secretary who might report to or consult with the Board if she wished. When the work of the agency was reduced in 1938, the plan of staff reductions was submitted by the General Secretary for Board approval as was the district and application department reorganization plan instituted following the chest survey.

A proportion of the Board remained opposed to the extension of the social Security Act to include the employees of charitable agencies. The General Secretary, however, secured their approvel in 1938 for inclusion in the 1939 budget of an item for the establishment of a retirement system. This request was refused by the Chest because of the possibility of changes in the Social security Act. The same year, in spite of the disapproval of the Chest, the Board approved the recomendation of the General Secretary that every effort be made to pay qualified case workers the $\$ 140.00$ monthly salary recommended. In 1939 the Board accepted the request of the General Secretary that as the majority of the Board membership had changed since sho was appointed, her own competency for the position should be reviewed. The same year the Board approved her recommendation that since the total salary decrease required in the approved budget could be absorbed in other ways, no reduction should be made in the case worke rs' salaries. The Nembership Committeo continued to give thoughtful consideration to the filling of vacancies in the Board. In 1940 in an 
effort to provide a more democratic base for selection, the Board approved the sending of letters to members of the agency who had attended the last several annual meetings asking for suggestions for Board membership.

Standing and Special Committees

The treasurer, as chaiman of the Finance Committee, continued to act as financial advisor to the General Secretary in the making of purchases, the drawing up of the annual budget and the study of the annual audit. Although the ontire Board was responsible for decisions as to when it was advisable to purchase and sell securities, the Finance Committeo was responsible for the actual sale and purchase. The treasurer was responsible for the Bequest Fund and for reporting periodically to the Board on the condition of the agency's investments. Selection of auditors was roted upon by the Board on the recommendation of the treasurer as was the transfer of funds between items of the budget. The General Secretary continued the practice of discussing the tentative budget with members of the Finance Committee then individually with all other Board members before it was presented to the Board as a body for approval.

Immediately following the Chest survey, the three standing committees, House, Case Policy and Nembership and Interpretation, were reorganized to include staff members and were asked to consider the Survey recomendations applicable to each. As has been indicated the special Committer on Revision of the Constitution and By-Laws was also created. 
The House Committee, after study of the recommendation that new quarters should be secured, reported to the Board on April 18, 1939 that the committee beliered it would be desirable to sell the buildings, and if legally possible, to avoid re-investment of the money in real estate. The committer made a detailed study of the condition of the Building Fund and the deed and secured the appraisal of all the properties by a Board member not on the committee. On May 16, 1939, the Board empowered the committee to act on the disposition of the buildings, either to sell or to lease, the amount and details to be left to the discretion of the comittee. It was later decided it was not wise to sell the buildings at that time because the probable return would be insufficient to cover the rental of other quarters. Members of the committeo made contacts with realtors and carried on negotiations that led to the leasing of one of the buildings.

The Committee on Membership and Interpretation, in addition to making nominations for Board membership, studied the interpretation needs of the agency. The committer planned an interpretive poster, not for the purpose of raising funds but to reach prospective clients, that was accepted by the Board in March, 1940. This poster was sent to schools, churches, social agencies and commercial and industrial establishments, each group accompanied by an interpretive letter from a Board member known to that particular group. This poster was the outgrowth of ideas expressed by the industrial group on the Board. Earlier the committeo had secured a Family Welfare Association motion picture and after its showing to rarious groups evaluated that type 
of publicity. To finance both these ventures the committee secured special contributions from several Bourd members. Extensive work was carried on during 1940, in cooperation with other Board members, in the preparation and financing of publication of the history of the agency and its adaptation in dramatic form. Mrs. R. P. Halleck served as advisor in the correction and verification of fectual material and the proof reading of copy.

In the development of marriage comseling service the agency found there was a need for the services of private physicians. Board member Dr. H. H. Hagan offered guidance in developing such service with a group of physicians.

The Case Policy Committee studied the recomendations of the Chest survey dealing with the agency before it was presented to the Board and to the Community Chest. Following the Survey, the committee reviewed, revised and put in witing the agency's policy in reference to personnel practices and salary schedules. This report was approved, with some changes, by the Board in January, 1940. The committee also recommended the re-opening of the question of retirement annuities and advised that if the Chest was making no such plans, the agency should proceed in its efforts to set up such a plan. In way, 1940, at the request of the General Secretary, the committee reviewed the agency's relationship to the national organization and recommended that efforts be made to interest Board members in becoming individual members of the national organization, that the Board be represented at meetings of the national association and that the dues of the agency 
be increased for 1941. Since $1938 \mathrm{Nrs}$. Corge Zubrod has served as agency representative to the Family Welfare Association. In 1939 Canon Clarke attended the National Conference of Social Work as a representative of the agency.

\section{Volunteers}

As was indicated in the preceding chapter, the trend of volunteer service in the agency was toward using volunteers in areas other than visiting of families. From 1938 to 1941 about forty-five clerical volunteers assisted with stenographic and receptionist work. Only nine volunteers were used in any kind of case work service as the problems families brought to the agency required the skill of professional workers. Two or three volunteers continued to give motor service. Initial training and placement of volunteers was concentrated in the Volunteers' Bureal of the Chest rather than in the agency. The agency's relationship with the Crescent Hill Social Service Comitter, which had been carried on since 1926, was discontinued in 1940. The families cared for by the committee were no longer those active with the agency and the committee agreed it would be wiser to establish a working relationship with the public agency. Annual Meotings

Annual me日tings of 1938 and 1939 followed the pattern established in the preceding period. Although Board members were active in securing attendance, responsibility for other details was left to the professional staff. In this area, as in others, the Board was disposed to believe its function was the initiation of new ventures, 
and that once practice was established it could be delegated to the staff. The annual meeting of 1940 was postponed. Throughout 1940 the Board through committees was active in the preparation of a play dramatizing the history of the agency as a new form of annual meeting.

\section{SUMARY}

The major developments of this brief period were focused in the cessation of public subsidy to the agency, clarification of function, and the re-organization of the agency set up and the derelopment of a service program following the Community Chest Survey. Many activities remain in the process of development. The re-organization of committees resulted in joint participation of Board and staff in revision of the Constitution and By-Laws, development of personnel policies, program of interpretation, and building operations . Responsibility for personnel was delegated to the Ceneral Secretary. Although the case work service was left entirely to the professional staff, the Board retained authority for revisions of policy and influencing the course of experimentation. The Board was cognizant of the relation of the agency's program to developments in the community and sought to aid in those developments wherever possible. Relations with the Community Chest were clarified and the agency's authority in questions of budget adjustment and salary schedules was recognized. Volunteer service decreased as the program of the agency required increased professional skills and the agency found difficulty in finding new areas for volunteer service. 
CHAPTER VII

DISTRICT CONFERENCES OF THE FAMILY SERVICE ORGANIZATION

$1922-1941$ 


\section{DISTRICT CONFERENCES IN THE FAMILY SERVICE ORGANIZATION 1 1922-1941}

Group activity in neighborhood or district conferences would provide an area for study in itself too large for the scope of this thesis. Since such conferences have been a definite form of lay activity in the Family service Organization, it seems wise to attempt to draw together some facts regarding their organization, membership and activity. Throughout the history of the agency there has been a conviction that community participation is essential to the full functioning of the agency. In some periods the impotus for such participation has com from the citizens, at other times from the staff; philosophy as to the use of citizens' groups has not always been clear, but the conviction has been ovident in some form in all periods.

As has al ready boen indicated, the founders of the charity Organization Society provided definite activities for the District Conferences of that period that constituted what would now be considered the case work of the agency. Conferences were organized on a district or neighborhood basis that fostered close contact botween

1. Material for this chapter, except where indicated, has been taken from minutes of District Conference meetings, membership lists, reports to the Board, and District Supervisors' meetings. There are many gaps in the District Conference minutes and great variation in the method and adequacy of recording of those that have been preserved. Fifty percent of the fifty minutes available for the 1929-1941 period were studied, twenty-five percent of the four hundred and twenty available for the 1929-1941 period. 
the membership and the agency's clients and sought to coordinate and make available to the clients all the resources of the district and the larger community. Ten such Conferences were active in the five years 1885 to 1890 , but the agency was not able to sustain interest after that tine, although evaluation as to the success or failure of tive Conferences is largely lacking.

In the Associated Charities era, scattered attempts were made at District Conference organization without notable success. Impetus for such participation, in that period, came not from the citizens but from the executive who felt the need of comunity participation in district organization and servic.

The number and continuity of Conferences has varied in the Family Service Organization. It is significant, however, that since 1924 such Conferences have been a consistent part of the organization with several Conferences functioning, usually bi-weekly for about seven months, each year. They have been spoken of periodically as District Conferences or Committees, Advisory Conferences or Committeөs, or Community Conferences, but for purposes of simplification they will be designated here as District Conferences. Except for the Fortland Cormunity, the Conferences have been identified with the district organization of the agency rather than with natural comriunities or neighborhoods.

Emphasis was placed on the first and last meetings of each year as these were more likely to outline plans and evaluate progress; where complete minutes were available, approximately every fourth meeting was studied. Early membership lists were not complete but recent lists make possible classification of the membership. 


\section{A. MEN BERSEIP}

In the early years of the Family Service Organization responsibility for selection of Conference membership was largely assumed by the Board, later it was shared with the ceneral secretary. In recent years much of this responsibility has boon assumed by the entire staff, the ceneral secretary in her relation to the Board passing on to the staff the comments and suggestions of the Board. Some suggestions have originated with community persons but final responsibility for selection has remained with the agency. In recent years several Conferences have experimented with lembership Committees which have aided the staff in enlarging the possibilities for membership. Membership of the various Conferences has reflected the interest and personality of the District Supervisoss and staff.

The Board in the early years of the Family Service Organization appointed one of its members as chaiman of each Conference. Within recent years the Conferences have elected their officers with varying degrees of guidance from the professional staff. District Conference membership has not been required of Board members but many Board members have served on the Conferences. Within recent years, the Board has drawn heavily from the Conferences for Board membership. There has been an increasing conviction that such experience gives a much clearer understanding of the actual work of the agency thanis possible from Board activity alone.

In the early years of the Family Service Organization, although membership lists were not accurately kept, it is evident that 
the Conferences were snall, probably averaging ten members. Membership was fairly ovenly divided among ministers, housewives, business men, agency representatives, and other professional persons.

In the family field, generally, there was a decrease in the use of District Conferences as private agencies transferred responsibility for besic relief to public departments. Since this development did not take place locally until a later period, a general policy of enlarging the Conferences prevailed from 1929 to 1935. All showed steady growth, although membership varied from nineteon to fifty-three among the various Conferences. Characteristics of membership varied; the Southern and Portland Conferences drew more heavily on neighborhood business men, housewives, ministers and teachers, while the Central and Western Conferences were made up largely of persons living or engaged in business or the professions in other than areas corresponding to the district organization. The Colored Conference has always show a somewhat different distribution of membership, being more largely a professional group, as there have been few Negro business men and women from whom to draw.

Membership was decreased after 1935 on a planned basis because the supervisory staff believed some of the Conferences were tending to become public forums. Attention was being directed by the agency toward a beginning transfer of relief responsibility to the public agency. It was believed to be important to have smaller groups whose attendance would be more regular in order that interpretation of changing function might be more adequately discussed. After the transfer of major 
relief responsibility in 1938, the agency was concerned that the community understend the division of work with the public agency and the developing service program of the private agency. It was agreed that closer contact between Conference members and staff was essential and that this would be facilitated by the dropping from membership of representatives of other social agencies. Some Conferences had a large proportion of social agency representatives and the community persons tended to leave responsibility to that group. The agency's need for conrunity thinking on the problems facing the agency was discussed with the social agency representatives before they were dropped from memborship.

The Conferences were comparatively small from 1938 to 1940 . The membership itself, in 1940, initiated discussion of the importance of enlarging the scope of interpretation and membership was the refore again increased. Efforts were made also to have each Conference representative of the entire cormunity. With the-exception of the Colored Conference, all have drawn more heavily upon business groups than formerly. In contrast to the Board, members of the Conferences have been chosen not only as individuals but as representative of groups and interests.

\section{B. FUNCTION}

The development of the agency has been reflected in the changing tunction of the District Conferences. From the agency point of view, the one function that has remained consistent throughout all periods has been that of interpretation to the community. 
In the early years of the Family Service Organization, Conference function was outlined as follows: "Each District Committeo will study and advise upon treatment of difficult problem cases, decide questions of district policy, and the use and location of district offuces." 2 This statement indicated a shift from the earlier participation in direct service to clients, 3 but still implied considerable activity in the case work of the agency. Periodically emphasis was focused on the responsibility of the Conferences for development of neighborhood and comrunity resources, but except as such needs were closely related to the agency's work, the Conferences largely failed to carry out this function. In this period when the agency staff had limited training, the Conferences were a source of much specific information and guidance to the workers. The authoritative approach of the case work of that period was reflected in similar responsibility

as sumed by the conferences. In exereising this function of individual case decisions, some Conferences for a time confused their function to include agency policy making, and it was necessary to clarify the difference in function between the conferences and the Board. In the period from 1924 to about 1935 concepts of the function of the Conferences varied among the District Supervisors. Some frankly believed the chief purpose was to "educate" members as to agency program, develment of social work, and understanding of behavior. Other Conferences

2. "Statement of Committees and Duties," 1924, op. cit.

3. "Rules for District Committees," 1884, and Constitution of the Charity Organization Society, Article XII, op. cit. 
reflected the belief that the members had much to give to the staff in understanding of community attitudes, resources and needs. The Board was aware of these differences of opinion among the staff but believed it wise to allow concepts to derelop gradually out of experience. Emphasis varied according to developments in the community but at all times attention was given to enlarging the knowledge of members as to the work of other agencies in the community.

As the professional skill of the staff increased and the emphasis of the agency shifted from a basic relief to a service program, the staff for a time was confused as to the function of the Conferences. They were conscious of their own increased skills, the change in agency clientele and the more specialized services offered, and they questioned the ability of the members to help in case work processes. Older Conference members, accustomed to giving specific recommendations; also questioned their usefulness to the agency. The thoughtful questioning of the members together with frequent staff discussions served in a comparatively short time to clarify the present Conference function. As workers becane more secure as to the future role of the agency, they recognized again the need for the knowledge of community resources members could supply and for community thinking on new problems and responsibilities of the agency. The Conferences were also visualized as a medium for reporting to the community how its contributed funds were being spent and of keeping close to cormunity thinking in the development of new services. The interpretive function of the Conferences continued as important as in earlier periods and was the 
area of responsibility most clearly recognized by the membership who were often loathe to believe they functioned in any other capacity.

C. SCOPE OF SERVICE

While emphasis varied throughout the years and among the Conferences at any particular time, the range of activities as a whole encompassed in a large measure the program of the agency. As was true of membership, the activities of individual conferences reflected the philosophy and interest of the District Supervisors and staff.

Focus of interest varied at different times but throughout this entire period the Conferences occasionally related their responsibility in individual case discussions to agency policy. They brought to the attention of the Board such questions as the need for more adequate care of the aged and the feeble-minded, for a home for Negro unmarried mothers, for facilities for dental care for needy Negroes, for publicity as to inadequate relief throughout the state and developing public employment services.

From 1922 to 1938, the general pattern of programs was discussion of individual cases. In two Conferences, for several years, identity of the client was not concerled, although in all, the confidential nature of the material was frequently stressed. The character of case presentations was illustrative of major problems concerning the agency at different periods. Thus prior to 1935, cases illustrating long time dependency occupied most of the Conferences' attention and after 1937 emphasis was turned to such areas as debt adjustment, family strains, adolescent adjustments, otc. 
The Portland Community Conference, representative of a closely knit community, more nearly approximated the Conferences of the Charity Organization Society era in its nany direct services to individual clients. These ranged from providing work opportunities, adjusting insurance, appraising property, and securing special gifts to providing friendly visiting and planning of an annual Christmas party for clients of the district. The Portlend Community Conference actually sponsored the district office, maintained a close contact with the staff and supplied many articles of equipment. When the Portland Community Conference was discontinued, responsibility for the annual Christmas party was assumed by the Portland Advisory Conference. This group believed that the planning of thisevent by committeos composed of Conference members, staff and clients was one of its most important aspects, as it provided contacts for the members with the agency's clients. Other Conferences also were similarly active in the early years of the Family Service Organization though not to such an extent. Its identity with the conmunity also resulted in the Portland Community Conterence early taking responsibility for improving resources in the community such as public playgrounds, special classes for adults, otc. In the early period when that community was both uninformed as to the agency's program and critical of it, the Conference took responsibility for planning several large neighborhood meetings, at which they secured Board representation and this did much to win support for the agency. In the period prior to 1938 , 2lthough ease work decisions of the Conferences were frequently authoritative and not always sound, 
very real service was given to the staff. This often took the form of support in relation to difficult decisions such as the withdrawing or continuing of relief, placement of children, return of non-residents, etc. Resources unknown to the worker were frequently suggested but possibly the chief service in this period was the widening of the workers' understanding of individual situations and of areas of service to the client.

Even in this early period, the interest and activity of several of the Conferences was not entirely confined to case discussions. In several instances stimulation of agency programs of interpretation originated in the conferences. The colored Conference was active in efforts to secure more adequate dental care for needy Negroes. In two instances, Central District Conference enlisted the participation of others in the community to join with the Conference in sub-committees, one year to study the housing and sanitation problems of the district, another year to study problems of care of the feeble-minded. In the first, active use was made of the recoramendations with city authorities. The Board forwarded the study of care of the feeble-minded, with the exception of that part which recommended sterilization of the feeble-minded and epileptic which it believed was within the province of the medical profession, to the Board of Education and the State Commissioner of Welfare. This latter study, because of its implications of agency policy served to clarify the difterence in function of the Board and the District Conferences. As the service function of the agency developed, the clientele of the agency gradually changed and many serious personality problems 
did not lend themselves to Conference discussion. The increased professional skill of the staff decreased the need for specific case discussion and emphasis was again turned toward social and community problems. Cases were less frequently presented in detail but rather in groups illustrative of the agency's service and community needs. The individual Conference members seldom offered direct services to individual clients, as in former years, but served rather to clarify for the Individual worker and the agency, community implications of Individual problems, community support or oriticism of new services, and agency responsibility for urmet needs.

\section{SUMMARY}

The lack of early records of Conference activity and the varying adequacy of more recent minutes limits the possibility of sound evaluation of this program. It is clear, however, that the conferences of the early eras functioned only spasmodically and were of doubtful value to the agency. With the exception of the Portland Community Conference, the values of neighborhood groups have been neither used nor stimulated. Throughout the entire Family Service Organization period it has been difficult consistently to focus interest on the community; the interest of the membership, in the main, has been in the human appeal of the families served by the agency.

It is difficult, if not impossible, to measure adequately the results of interpretation to the Conferences. Some criteria are available however. A few clients have been referred to the agency by 
by members. The executive of the Community Chest has frequently indicated that members serving as campaign solicitors give evidence of the knowledge and interest gained from the Conferences. Board members most able to act on agency policy have been those who have had District Conferonce experience. Changes in understanding and awareness of social problems are frequently ovident in the contributions of individual members to discussions.

The size of the Conferences has varied in different periods and in different Conferences. Present Conferences are more representative of the community than was true earlier. There is need, however, for continued study of the membership so that among the various Conferences all sectors of the community will be represented. Function has gradually evolved out of experience and the changing program of the agency. Activities have varied according to the interests and capabilitios of the membership, community and argency needs, and the philosophy of the District Supervisors and staff. Nany specific services have been given both to individual clients and to the agency. For the staff, the conferences have provided a tangible link with the community that has served to widen opportunities for service, clarify function and answer criticism.

The continued activity and increasing contribution of the Conferencesin the last ten years points the way to future possibilities of community participation. There has been more realistic facing of the agency's dependence on community support and more joint sharing of responsibility among the Board, the staff and the Conferences. 
Out of the varying confusions of the past has come the conviction that the agency can use the services of such citizens' groups and that their support and understanding of the agency's program can serve as a guide in the development of both services and interpretation. Basic to future development of such participation would soem to be the clarifying of the need ror records of Conference activity and for evaluation of membership. There is almost no recorded information as to attendance or interest that would make possible sound selection from previous Conference membership of those who might again give service to the agency, Although there has been more study of comunity participation by the staff than has been recorded, it has often been considered as something extra rather than an essential part of the job. This may be related to the fact that both the Board and the ceneral Secretary, being elear as to the philosophy of such participation, have failed to interpret this philosophy adequately to the staff. Although the keoping and study of case records has long been recognized as basic to the development of case work skills, there has been little attention to similar possibilities in the area of community participation. The lack of either training or experience in group activity and the concentration on case work by the staff has resulted often in insecurity and ambivalence of feoling that has limited Conference development. Gaps in interpretive program seem related to insufficient coordinated planning. The sharing of responsibility for selection of membership with the Conference members, and the increase in sharing of responsibility among the staff in 
recent years both seem to indicate future trends. The earlier plan of periodic joint meetings of the District Conferences with the Board, that served to unify program and strengthen identification with the agency as a whole, has not been used in recent yoars. There is a strong indication that these values again will be realized. Two representatives of each of the white Conferences meeting with the General Secretary and supervisory staff in the fall of 1940 laid the ground work for resumption of joint meetings as well as more coordinated planning. The development of leadership, both lay and professional, in community participation is a challenge for the future success of the District Conference program, and perhaps even for the success of the whole agency program. 
CONCLUSION 


\section{CONCLUSION}

The Family Service Organization is a private society whose management throughout its history has been vested in a Board of Directors, or Central Council, who have delegated varying portions of the actual work of the agency to standing and special committees and to the stafe. In some periods the Board has been dominant, at other times major responsibility has been carried by the Executive Comitter. Revisions in Constitution and By-Laws have altered from time to time the number and the responsibilities of the citizens identified with the work.

Function has been altered to fit the changing needs of the community in which the agency has had its setting. Organized as a society not to dispense relief directly, but to "foster harmonious cooperation" among the various existing churches and charitable agencies, to investigate need, to obtain "from the proper charities and charitable individuals suitable and adequate relief for deserving cases", to "secure work for poor persons", to "repress mendicancy" and to "promote the general welfare of the poor", early leaders reluctantly accopted the noed for the agency's dispensing relief in emergency situations. By the ond of its second period of development in which it sought to further cooperation by centering all charitable activitios in the Associated Charities, the function of not only emergency but continued or basic relief had been accepted. With the responsibility for coordinated fund raising transferred to the Welfare 
League, later the Community Chest, the society sought to emphasize its function of service to families by the change in name to the Family Service Organization. During the emergencies of the depression period it was necessary for a brief period to eliminate the service program in order to meet mass relief needs, but as public responsibility for unemployment was accepted, the agency began to resume its service program. With the cessation of public subsidy in 1938, the agency's function was clarified as that of offering "advice and counsel on family problems" in addition to or coincident with extending financial aid to families in need but not eligible for public funds. Changes in the social philosophy of the citizens who constitute the organization has boen reflected in the changing function of the society. The emphasis first placed on the moral causes of poverty gradually gave way to an acceptance of the relation between economic conditions and poverty. The early philosophy, which continued to influence the program until the decade of the $30^{\prime} \mathrm{s}$, that private charity was the answer to the problems of poverty, gradually was superseded by an acceptance of public responsibility for basic neods. The abolition of the work test, the acceptance of the need for more adoquate relief and for Mothers' Aid legislation as a partial answer to the earlier practice of placement of dependent children, the delegation to and division of responsibilities with other agencies and new concepts of interpretation were evidences of the changing philosophy of those who guided the development of the society. 
The relation of the society, to organized religion would seem to offer a field of study in itself. Emphasis was placed early on the separation of the society from organized religion. Although efforts were made to win the cooperation of church groups, little success was attained except in isolated instances or for brief periods. It seems significant that one of the most frequent suggestions given to the staff by the District Conferences has been the strengthening of church contacts. Evaluation of interpretation to church groups, and an understanding of the churches' programs and attitude toward the agency's counseling service would seem an important area of future study.

Nembership in the organization was first limited to those persons who made an annual contribution to the society. With the organization of the Welfare League all contributors to that organization were considered members of the society, but by 1928, contribution of five dollars annually to the Community Chest was made the requisite for membership. Current membership is recruited not only from that group but provision has been made that persons who have expressed interest in the organization and a desire to be "sympathetically associated with it" may be elected to membership by the Board. Membership of the Board, elected at the annual meetings of the society, has been almost entirely drawn from suggestions of the directors. Standing comittees, except for a bries period when they were partially composed of members other than directors, have been appointed by the president from the membership of the Board. 
Membership of the District Conferences has not been limited to the members of the organization.

It is difficult to determine whether the membership has been representative of the community. It is evident that early membership was small and predominately represented wealth and position in the community. Although the basis of membership has been gradually broadened, it cannot be said to represent all groups in the community. Since many contributors to the agency through the chest are actual or potential clients of the agency, the broadening of the base of participation would seem to be an important area for future consideration. Qualifications for Board membership have gradually changed with the result that instead of representing groups or interests, members have beon chosen in recent years as individuals free to speak and act for themselves.

Degree of interest in legislation and social planning has varied in different periods but has been present throughout the history of the society. In cooperation with other organizations, the early society was instrumental in the creation of many other agencies and the securing of needed community services as a part of city government. Endorsement of and at times active lobbying for social legislation was a responsibility seriously undertaken by early leaders. In the Associated Charities era such activity was sustained and the organization played an important part in the organization of or laid the ground work for the beginning of such agencies as the Welfare League, the Legal Aid Society, the Social Service Exchange, the Social 
Service Departrent of the City Hospital, the Charities Endorsement Committee of the Board of Trade, and the inclusion of school nurses in the program of the Board of Education. Important contributions were made to legislation in the fields of housing, protection of small loans and the social control of contagious diseases. Activities in the field of employment services provided much of the preparation for the establishment of federal employment services. There was significant lessening of such activities with the beginning of the more specialized function of the agency and the delegation of responsibility to the professional staff. The stimulation of participation in social action is a challenge for the future to both professional and lay leadership. The chief interest of the period of the 20's was the securing of Mothers' Aid legislation and in this movement the agency played a significant part. Even prior to the depression period beginning efforts were made to secure improved public service in the care of the aged, the chronically ill and the mentally deficient. Planning for assumption of public responsibility for relief was limited at first to the securing of subsidy to the private agency, but led gradually to active offorts that resulted in the creation of the public agency.

In becoming a member of the Community Chest the agency transferred responsibility for fund raising to the chest and entered into its programs of coordinated social planning through representation on the chest councils. The many conflicts between the agency and the chest arose in part from the reluctance of the agency to give up 
quthority, from differences in points of view and interests and honest differences of opinion. The Board clung to the agency's authority over its internal management and its position gradually came to be accepted by the Chest.

As public relief programs developed there was a considerable period of confusion 28 to division of responsibility. Although the city instituted a work relief program in 1930, the private agency continued through public subsidy to carry the major responsibility for direct relief until after the establishment of federal relief programs. Clarification of division of responsibility began in 1935 with the transfer of some groups of families to the public agency and was culminated with the cessation of public subsidy in 1938. With responsibility for basic relief transferred, the Family Service Organization was ablo again to develop a program of service to families wishing counseling in respect to family problems and of consultation service to other agencies. While relief remained a part of that service, it was used for special and preventive services and largely in families not eligible for public relief.

There has been little use of the neighborhood approach in community planning. The early eftorts to develop District Conferences to care for the needs of each neighborhood were largely unsuccessful. For a brief period in the late $20^{\prime} \mathrm{s}$ and early $30^{\prime} \mathrm{s}$ there was some success in the organization of the Portland community, but as the function of the agency changed, those gains were not preserved and both the district office and the District Conference were discontinued. 
As has been indicated no adequate study of the District Conferences has been attempted and this area of group participation offers a field for further study. Success with this form of participation has been uneven, has been largely dependent on the interest and ability of the District Supervisors and staff, but has seemed to show increasing value to the agency in recent years. The Conferences have provided an important link between the egency and the community, have been one of the chief media of interpretation of the agency's program and needs and have, because Conference members were representative of groups and interests in the community, provided a basis both of accounting to the community and keoping the agency's program adapted to community needs. Increased participation of the Conferences in social action, the relating of their work to social action engaged in by the Council of Social Agencies, and the inclusion of client participation in the Conferences would seem to be possible future trends in District Conference organization and activity. In the early years, the Board delegated little other than deteil work to the small paid staff. The laymen were the society, so completely did they influence and carry on its work. Gradually as the Board gained confidence in the staff whose professional skills were steadily increased, responsibilitios in many areas were delegated by the Board to the professional staff. In the area of case work the Board, who had at first authorized the granting or withholding of relief in individual cases, gradually considered only cases involving unusual policy. When the agency accepted the function of 
contimed relief, the responsibility for reviewing and authorizing such cases was delegated to the Advisory Committeo. As the staff gradually became a professional group this authority was relinquished, and by the end of the first period of development of the Family Service Organization the Board was participating little in the case work except in the defining of broad policies of function. The area of inter-agency relationships showed the same trend of gradual delegation of authority to the ceneral secretary. Much of the time of the Board and the Executive Committee in the early years was deroted to the details of personnel practice and policy. This responsibility was continued with only slight changes until recent years when the Board, although continuing to approve general personnel policy and salary schedules, delegated complete authority to the General secrotary for employment and dismissal of staff. The strong support given to the staff during the critical depression period was a vital factor in the maintaining of morale. The Board and its committees were responsible for the policios and financial administration of the agenoy, were a constant source of guidance to the General secretary, and in the fields of interpretation, building management and financial policy supplied technical skills not possessed by the professional staff. The development of more mutual understanding on the part of the Board, the staff and the District Conferences as to the responsibilities or each group is important if the agency is to render its best service to the community. 
As the services of the agency have become specialized it has become more difficult to interpret the agency's work to the citizens interested in it. The District Conferences have questioned their help to the professional staff, yet have been reluctant at times to turn their interest to community problems of concern to the agency. Workers have found it increasingly difficult to interpret to lay groups the processes of treatment and have been confused as to how to maintain and make use of the service of lay groups. In the early days volunteers derived much satisfaction from their direct services to clients whereas the professional worker now stands between the layman and the client. The preserving of the positive values of the earlier practice and at the same time the protecting of the client seoms basic to the development of future programs of volunteer service. The transfer of responsibility to the Community Chest for fund reising, while broadening the base of support, has resulted in lessening of identification of contributing citizens with the individual ageneies. The clarification of what portion of specialized service can be interpreted to the layman and the correlation between that understanding and the support of the agency is a challenge to the future of the private family agency. There is evidence that the agency exists and operates in the community only to the extent that there is participation and support on the part of the citizenry and such participation demands the highest type of both lay and professional leadership. 
BIBLIOGRAPHY 


\section{BIBLIOGRAPHY}

\section{A. BOOKS}

Breckenridge, Sophonisba P., Public Welfare Administration in the United States, Chicago, The University of Chicago Press, 1927.

Brown, Josephine C., Public Relief, 1929-1939, New York, Henry Holt and Company, $1 \overline{940 .}$

Devine, Edward $\mathrm{T} .$, When Social Work Was Young, New York, The Macmillan Company, 1939 .

Johnston, J. Stoddard, Memorial History of Louisville, Chicago and New York, American Biographical Publishing Company, 1896.

King, Clarence, Social Agency Boards and How to Make Them Effective, New York and London, Harper and Brothers, 1938.

Kinkead, Elizabeth Shelby, A History of Kentucky, New York, Cincinnati, American Book Company, 1909 .

Kurtz, Russell H., "Public Relief," Social Work Year Book, New York, Russell Sage Foundation, 1935.

Libbey, Betsey, "Femily Social Work," Social Work Year Book, New York, Russell Sage Foundation, 1937.

Lindeman, Eduard C., The Community, New York, Association Press, 1921.

Lund, Harold H., "Family Social Work," Social Work Year Book, New York, Russell Sage Foundation, 1939.

Odum, Howard W., Chapter XXIV, "Public Welfare Activities," Recent Social Trends in the United States; Report of the President's research committee on social trends, New York and London, McGraw-Hill Book Company, 1933.

Pettit, Walter W., Case Studies in Community Organization, New York and London, The Century Company, 1928.

Queen, Stuart Alfred, Social Work in the Light of History, Philadelphia and London, J.B. Lippincott Company, 1922.

Richmond, Mary E., The Long View, New York, Russell Sage Foundation, 1930.

Street, Elwood, Social Work Administration, New York and London, Harper and Brothers, 1931. 
Warner, Amos G., American Charities; A Study in Philanthrophy and Economics, Now York and Boston, T.Y. Crowell and Company, 1894.

Watson, Frank D., The Charity Organization Movement in the United States, New York, The Macmillan Company, 1922.

B. PAMPHLETS AND PROCEEDINGS OF ASSOCIATIONS

The National Conference of Social Work:

Dunham, Arthur, "The Literature of Community Organization," $1940,413-25$.

Eggleston, Mary L., "Relation of Case Work Staffs to Interpretation, Officials, Governing Boards, Volunteers, and the Public," 1938, 233-42.

Ernst, C. F., "Use of Friendly Visiting," 1937, 517-22.

Farra, Kathryn, "Neighborhood Councils," 1940, 447-56.

Hollander, Sidney, "Confessions of a Board Nember," 1939 , $550-61$.

Hollander, Sidney, "A Layman Takes Stock of Public and Private Agency Functions," 1937, 174-91.

Howlett, Virginia, "Relation of Case Work Staffs to Interpretation, Officials, Governing Boards, Volunteers, and the Publio," 1938, 242-51.

Johnson, Arlien, "The Obstacle of Limited Participation in Local Social Planning," 1940, 425-36.

Kurtz, Russell H., "The Range of Community Organization," 1940, 400-12.

Lane, Robert P., "The Field of Cormunity Organization," 1939, 495-511. 
Lindeman, Eduard C., "New Patterns of Conmunity Organization," $1937,317-23$.

Pratt, Mrs. J. G., "Lay Participation in Social Work; Now opportunities for the Volunteer," 1934, 217-23.

Shields, Wilmer, "The Importance of the Layman in Community Organization," 1938, 422-30.

Publications of the Fanily Welfare Association of America, New York:

Dodd, Ruth M., "Volunteer Values, " 1934.

McLean, F. H., "The Family Society; Joint Responsibilities of Board, Staff and Membership," 1927.

Swift, Linton B.," New Alignments between Public and Private Agencies," 1934.

"Now Perspectives in Family Social Work," 1935.

"Family Social Work in Transition," 1938.

"The Function of Fanily Case Work Agencies as Defined by Boards and Staffs," 1937.

"Case Work and the Cormunity," 1926.

"Family Social Work and the Community," 1935.

"Case Committees," Department of Studies and Information, 1940.

Jackson, James F., "The Relationship between a Board of Directors and the Professional Social Worker," Western Reserve University, 1924.

Community Chests and Councils, New York, "The Neighborhood Approach to Community Planning, "1937.

Social Planning Council, St. Louis, "The Tower Grove Area Project," 1940.

\section{PERIODICALS}

The Family:

Beck, R. E.," Her Partner, the Public," Vol. XVII, January, 1937, 299-301. 
Bowen, Janice and White, Mrs. Robert E., "Why a Case Committee?" Vol. XX, March, 1939, 19-21.

Churchward, H. P., "An Experiment in Client Participation," Vol. XVII, April, 1936, 43-48.

Drummond, Agnes, "A District Case Comnittee," Vol. XX, March, 1939, 17-19.

(Editorial) - " Lay Leadership in Family Social Work," Vol.XVII, January, 1937, 310-13.

Emery, Marian, "A Volunteer Project with a Group of Adolescent Girls," Vol. XVI, December, 1935, 247-51.

Galt, D.H., "Growth of a Case Cormittee," Vol. XV, June, 1934, 112-15.

Hemingway, M.D. and Brown, J.L., "A Case Committee," Vol. XVII, April, 1936,35-9.

Margolis, L.L. and Waldman, E.R., "A Study of Thirty-two Cases in Which Volunteers Have Been Used as a Treatment Tool," Vol. XV, December, 1934, 268-72.

Matson, Ruth A., "The Contribution of a Case Committer," Vol. XIX, June, 1938, 109-11.

Neusteedter, Eleanor, "Along What Lines Does the Future Contribution of the Family Welfare Movement Lie?" Vol. XX, June, 1939, 123-30.

Rich, Margaret E., "Philosophy and Program of a Private Family Agency," Vol. XIX, January, 1939, 283-89.

Rockefeller, Mrs. J.D. III,, "Layman Looks at Family Welfare Tork," Vol. XV, December, 1934, 247-9.

Swift, Linton B.," The Purpose and Program of a Family Case Work Agency," Vol. XX, March, 1939, 3-7.

Todd, Helaine A., "Joint Cormittees of Board and Staff," Vol. XVI, July, 1935, 145-49.

Tousley, Clare M., "Social Work and the Public," Vol. XX, March, 1939, 15-17.

Jihlein, Ralph A., "Joint Responsibilities of Board and Staff," Vol. XXII, Hay, 1941, 67-73.

Waite, Florence T., "Case Work - Today and Fifty Years Ago," Vol. XXI, February, 1941, 315-23. 
Wead, Margaret, "Local Membership Plans in Family Welfare Agencies," Vol. XVI, June, 1935, 102-8.

Wilson, Barbara and Beckman, Muriel, "Volunteers Discuss Their Cases," Vol. XIV, December, 1933, 265-7.

Family Welfare Association of America - News Letter

"Experiment in a Case Cormittee," Vol. XIII, November, $1938,49$.

"The Case Comittee in Rochester," Vol. XIII, April, 1938,7 .

"From a Case Committee," Vol. XII, July, 1937, 32.

"Case Committee in a Private Agency," Vol. XI, June, $1936,20$.

The Compass

Lund, Harold H., "Stake of Lay and Professional Groups in Social Work," Vol. XIX, October, 1937, 13-15.

Channels

Towley, Louis, "Public Welfare's Untold Story," Vol. XVIII, October, November, 1940, 165-7.

\section{Eighlights}

Black, Bertram, "Interpretation Designed for Neighbors," Vol. I, December, 1940, 115.

Carter, Elizabeth M., "Reading and Writing by Board Members," Vol. I, December, 1940, 116-17.

Chester, Mrs, Mildred A., "Training for Board Membership," Vol. I, May, 1940, 41-42.

Choate, Mabel, "Who Are Our Board nembers?" Vol. I, January, $1941,145$.

Cobb, Mrs. Boughton, "Case Fork as a Science," Vol. I, October, 1940, 83-84.

Gulick, Mrs. Luther, "A Case Comittee Member Does Some Thinking," Vol. I, April, 1940, 21. 
Loveman, Mrs. Herbert, " A Volunteer Program: 1940," Vol.I, December, 1940, 113-15.

Savin, William H., "Board Presidents Report on Progress," Vol. I, October, 1940, 89.

Sterm, Selma G., "Special Services of a Volunteer," Vol. II, March, 1941, 3-5.

-..- "Diary of a Volunteer: 1889," Vol. I, November, 1940, 105-6.

Survey Midmonthly

Baker, Helen Cody, "Grandma Called It Charity," Vol. LXXVI, November, $1940,315-17$.

Close, Kathryn, "Volunteers in Critical Times," Vol. IXXVII, January, $1941,8-10$.

Harvie, R. H., "Board Member Soul Searching," Vol. LXXIV, Narch, 1938, 74-6.

Henry, Barklie, "We Take a Lot on Faith," Vol. LXXVI, November, $1940,319-22$.

Kelso, R.W., "Why Is a Board of Directors?" Vol. LXVI, October, 1931, 77-9.

Newbold, F. L., "What About Volunteers?" Vol. IXXIII, July, $1937,214-16$.

North, W.W., "Volunteer Venture," Vol. LXXIII, February, 1937, 39-40.

Pleuthner, Mrs. Willard A.," We Believe in Social Workers, but...," Vol. IXXVI, November, 1940, 317-19.

Springer, Gertrude and Close, Kathryn, "The Meeting Will Please Come to Order," Vol. LXXVI, November, 1940, 322-28.

--- "Quiz for Boards and Their Members," Vol. LXXVI, November, $1940,328-29$. 
D. MISCELLANEOUS

Family Service Organization Material

Minutes - Board of Directors, 1912 - 1941.

Minutes - Executive Committee, 1917 - 1931.

Minutes - District Conferences, 1924 - 1941.

Minutes - Standing and Special Committees.

Minutes - Supervisors' Meetings.

Reports - of the General Secretary and the District Supervisors.

Annual Reports - The Louisville Charity Organization Society, 1884 - 1897; 1902 - 1907.

Annual Reports - The Associated Charities, 1907 - 1922.

Annual Reports - The Family Service Organization, 1922; 1925-1940.

Constitution and By-Laws of the Louisville Charity Organization Society, 1884.

Articles of Incorporation, 1884, Amended 1907, 1922.

By-Laws of the Associated Charities As Amended to July 2, 1917.

Constitution and Ey-Laws of the Family Service Organization of Louisville and Jefferson County, Kentucky, Amended 1928, 1939.

Preliminary Report - Family Welfare Committee of the Community Chest Survey, March, 1939.

Louisville Charity Organization Society, "Rules for District Committees," February, 1884.

Letters, articles, reports, and publicity from the files of the Family Service Organization.

Gurteen, Reverend S. Humphreys, Chicago Charity Organization Society, "Hints and Suggestions to the Visitors of the Poor," reprinted by the Louisville Charity Organization Society,1884. 
Lowell, Mrs.Charles R., "Duties of the Friendly Visitor," Charity Organization Society, New York City, reprinted by the Louisville Charity Organization Society, 1884.

Taylor, Esther M., "General Secretary's Report of the Agency's Activities, August, 1930 through December,1939."

Tymes, Harriet L., "The Relationship between Public and Private Agencies," 1931.

References in "The Courier-Journal, " "The Evening Times," "The Commercial," "The Louisville Herald " and "The Evening Post ".

Theses

Ellis, Mrs, Bernice W.," The History of the Family Service Organization of Louisville, Kentucky, 18841939," (in preparation).

Krupp, Mrs. Rebecca Baer, "Neighborhood House: A Settlement's Part in Social Planning," Uni versity of Louisville, 1939.

Prinz, Marian E.," A Study of the Fanily Service Organization, Louisville, Kentucky, in Reference to Intake, 1884-1940, "University of Louisville, 1941.

Sunley, Emil McKee, "The Kentucky Poor Lews, 1792-1936," University of Chicago, 1938.

Other Reports

Durrett, Ruben T., "The Centenary of Louisville," Filson Club Publication $\$ 8,1893$.

Lilly, Gregory, "The Bureau, Its History and Growth of Policy," Louisville, 1935.

Strong, Margaret K., " Public Welfare Administration in Louisville, Kentucky," 1935.

The Welfare League of Louisville, Kentucky," The Cormunity," March, April, 1919. 